\title{
Highly Tactic Cyclic Polynorbornene: Stereoselective Ring Expansion Metathesis Polymerization (REMP) of Norbornene Catalyzed By a New Tethered Tungsten- alkylidene Catalyst
}

\author{
Stella A. Gonsales, ${ }^{1}$ Tomohiro Kubo, ${ }^{2}$ Madison K. Flint, ${ }^{1}$ Khalil A. Abboud, ${ }^{1}$ Brent S. Sumerlin ${ }^{2, *}$ \\ and Adam S. Veige ${ }^{1,2, *}$ \\ ${ }^{1}$ University of Florida, Department of Chemistry, Center for Catalysis, Center for Macromolecular Science \& \\ Engineering, P.O. Box 117200, Gainesville, Florida, 32611 \\ ${ }^{2}$ University of Florida, Department of Chemistry, George \& Josephine Butler Polymer Research Laboratory, Center \\ for Macromolecular Science \& Engineering, P.O. Box 117200, Gainesville, Florida, 32611
}

\section{Table of Contents}

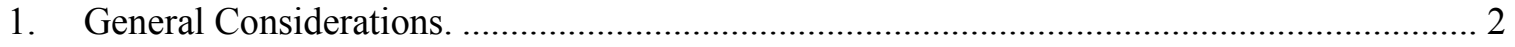

2. Synthetic procedures for 2, 3, BMCNBD, poly(NBE) and poly(BMCNBD) ....................... 3

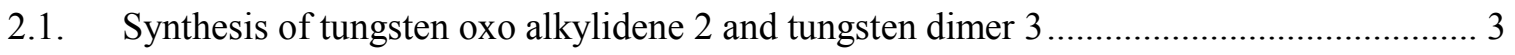

2.2. Synthesis of 2,3-Bis((menthyloxy)carbonyl)norbornadiene (BMCNBD) .......................... 4

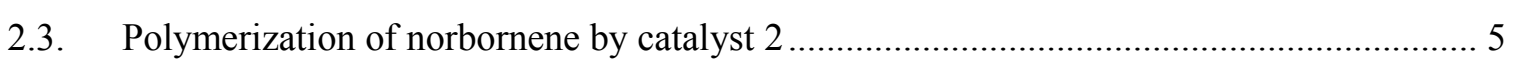

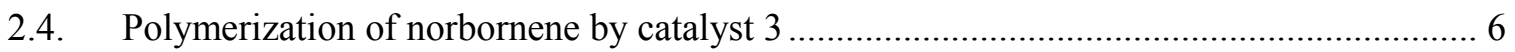

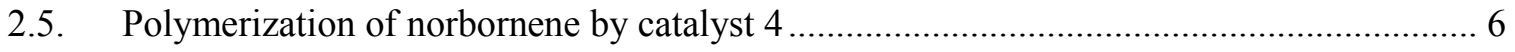

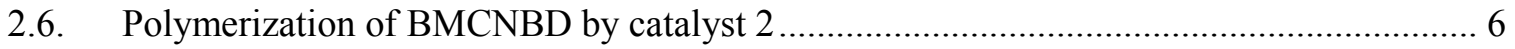

3. NMR Spectroscopic data for 2, 3, BMCNBD, poly(NBE) and poly(BMCNBD)................. 7

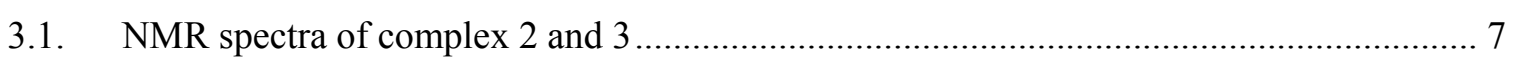

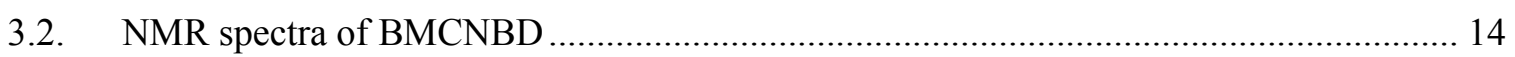

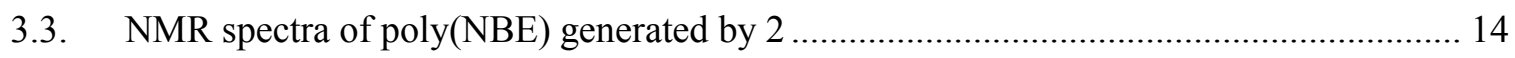

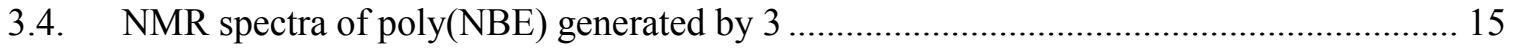

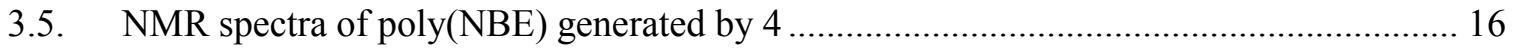

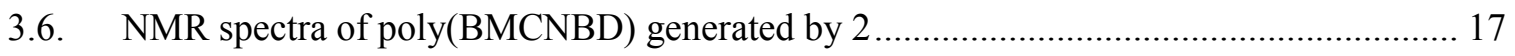

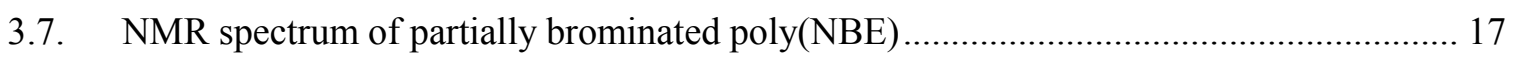

4. Gas Chromatography/Electron Ionization-Mass Spectrometry (GC/EI-MS)...................... 18

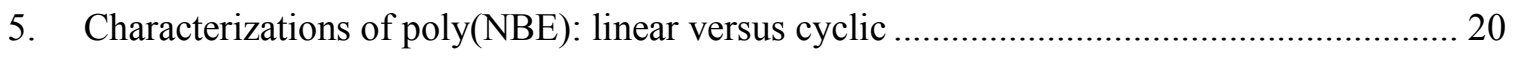

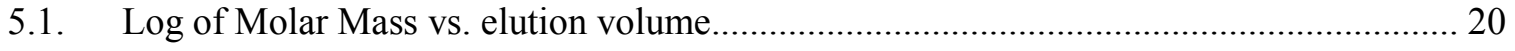

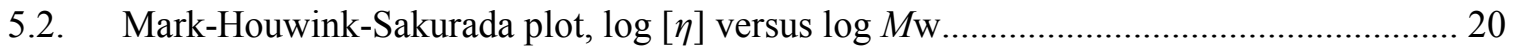

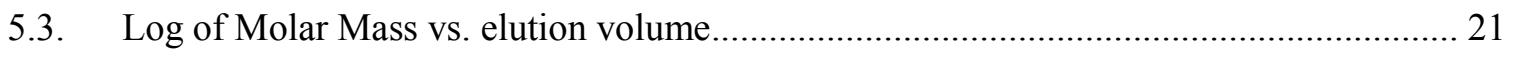

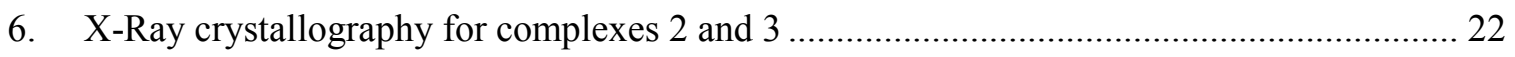

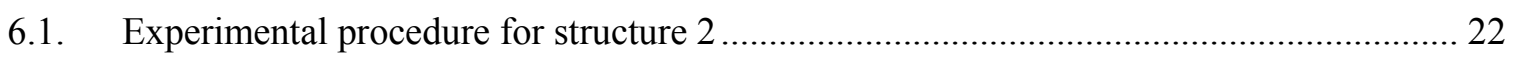

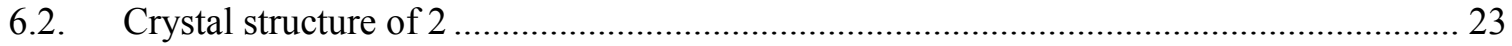




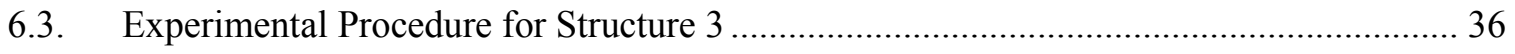

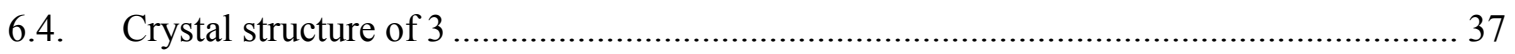

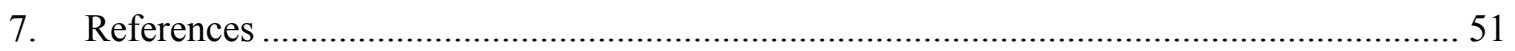

\section{General Considerations.}

Unless otherwise specified, all manipulations were performed under an inert atmosphere using glove-box techniques. $\mathrm{C}_{6} \mathrm{D}_{6}$ (Cambridge Isotopes) was dried over sodium-benzophenone ketyl, distilled or vacuum transferred and stored over $4 \AA$ molecular sieves. Norbornene was refluxed over sodium, distilled and stored under argon. The tungsten-alkylidyne $[\mathrm{OCO}] \mathrm{W}\left(\equiv \mathrm{C}^{\mathrm{t}} \mathrm{Bu}\right)(\mathrm{THF})_{2}$ (1) was prepared according to published procedures. ${ }^{1}$ Linear cissyndiotactic-polynorbornene (cis-poly(NBE)) was synthesized using the commercially available Grubbs catalyst $4 .{ }^{2}$ Complex 4 was purchased from Sigma-Aldrich (CAS 1352916-84-7) and used as received. Partially brominated poly(NBE) was synthesized according to literature procedures. ${ }^{3}$ ${ }^{1} \mathrm{H}$ and ${ }^{13} \mathrm{C}$ NMR spectra were obtained on Varian INOVA spectrometer $(500 \mathrm{MHz})$, or a Mercury (400 MHz and $300 \mathrm{MHz}$ for proton). Chemical shifts, reported in $\delta$ (ppm), were referenced on the solvent, on the TMS scale for ${ }^{1} \mathrm{H}$ and ${ }^{13} \mathrm{C}$. Elemental analyses were performed at Complete Analysis Laboratory Inc., Parsippany, New Jersey. Size-exclusion chromatography was performed in $\mathrm{THF}$ at $35^{\circ} \mathrm{C}$ and a flow rate of $1.0 \mathrm{~mL} / \mathrm{min}$ (Agilent isocratic pump, degasser, and autosampler; columns: three PLgel $5 \mu \mathrm{m}$ MIXED-D mixed bed columns, molecular weight range 200-400,000 g/mol). Detection consisted of a Wyatt Optilab rEX refractive index detector operating at $658 \mathrm{~nm}$, a Wyatt miniDAWN Treos light scattering detector operating at $656 \mathrm{~nm}$, and a Wyatt ViscoStar-II viscometer. Absolute molecular weights and molecular weight distributions were calculated using the Wyatt ASTRA software. Electrospray ionization mass spectrometry (ESI-MS) spectra were collected by direct injection into an Agilent 6120 TOF spectrometer at a gas temperature of $350{ }^{\circ} \mathrm{C}$ with fragmentation voltage of $120 \mathrm{~V}$. The sample 
was prepared in an argon glovebox and transported in Hamilton gastight syringes. Gas chromatography electron ionization mass spectrometry (GC/EI-MS) to identify CO was performed using a Restek Corp. Rxi-5MS column (30 m x $0.25 \mathrm{~mm}$ i.d. and $0.25 \mu \mathrm{m} \mathrm{df}$ ). A Finnigan Trace GC Ultra chromatograph was employed using split injection mode, with a split flow rate of $30 \mathrm{~mL} / \mathrm{min}$ and a $\mathrm{GC}$ carrier gas flow of $1 \mathrm{~mL} / \mathrm{min}$, vaccum compensated. Temperature at the injection port was of $250{ }^{\circ} \mathrm{C}$, MS transfer line was at $225{ }^{\circ} \mathrm{C}$, and a temperature program of $35{ }^{\circ} \mathrm{C}$ Isothermal was utilized. A ThermoFinnigan (San Jose, CA) Finnigan Trace DSQ mass spectrometer was used with an electron ionization (EI) of $70 \mathrm{eV}$, and ion source temperature of $250^{\circ} \mathrm{C}$.

\section{Synthetic procedures for 2, 3, BMCNBD, poly(NBE) and poly(BMCNBD)}

\subsection{Synthesis of tungsten oxo alkylidene 2 and tungsten dimer 3}

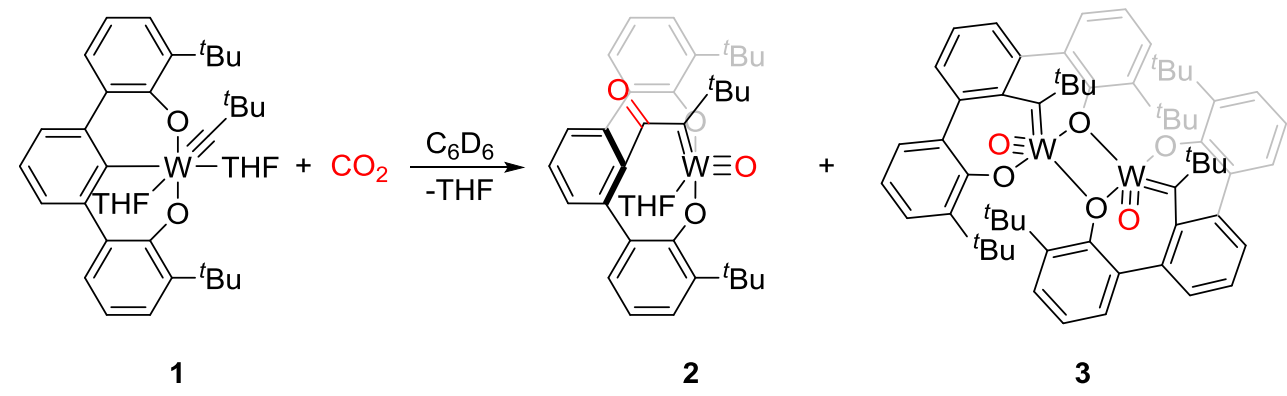

Scheme S1. Synthesis of compounds 2 and 3.

A J-Young NMR tube was charged with tungsten alkylidyne $[\mathrm{OCO}] \mathrm{W} \equiv \mathrm{CC}\left(\mathrm{CH}_{3}\right)_{3}(\mathrm{THF})_{2}$ (1) $(0.050 \mathrm{~g}, 0.065 \mathrm{mmol})$ in $\mathrm{C}_{6} \mathrm{D}_{6}$. After performing a freeze-pump-thaw procedure to evacuate the headspace of the tube, $1 \mathrm{~atm}$ of $\mathrm{CO}_{2}$ was admitted into it. Heating up the reaction up to $55^{\circ} \mathrm{C}$ for $12 \mathrm{~h}$ generates the tungsten oxo alkylidene $\mathbf{2}$, along with complex $\mathbf{3}$ in a 9:2 ratio, respectively. The solvent was evaporated under reduced pressure yielding a red powder. $2{ }^{1} \mathrm{H}$ 
$\operatorname{NMR}\left(\mathrm{C}_{6} \mathrm{D}_{6}, 500 \mathrm{MHz}\right) \delta(\mathrm{ppm}): \delta 7.32(\mathrm{~d}, 2 \mathrm{H}, \mathrm{Ar}-H), 7.27(\mathrm{~m}, 2 \mathrm{H}, \mathrm{Ar}-H), 6.94(\mathrm{~d}, 1 \mathrm{H}, \operatorname{Ar}-H)$ $6.88(\mathrm{~m}, 2 \mathrm{H}, \operatorname{Ar}-H), 6.83(\mathrm{~m}, 2 \mathrm{H}, \mathrm{Ar}-H), 1.65(\mathrm{~s}, 18 \mathrm{H}), 1.28(\mathrm{~s}, 9 \mathrm{H}) \cdot{ }^{13} \mathrm{C}$ determined by ${ }^{1} \mathrm{H}-{ }^{13} \mathrm{C}$ gHSQC and gHMBC experiments: $\left(\mathrm{C}_{6} \mathrm{D}_{6}\right): \delta=273.4(\mathrm{~s}, \mathrm{~W}=C \alpha), 185.81(\mathrm{~s}, \mathrm{~W}=\mathrm{CCO}), 168.0(\mathrm{~s}$, $\operatorname{Ar} C), 144.5$ (s, $\operatorname{Ar} C), 137.5$ (s, $\operatorname{Ar} C), 134.9$ (s, $\operatorname{Ar} C$ ), 131.7 (s, $\operatorname{Ar} C$ ), 130.0 (s, $\operatorname{Ar} C), 127.5$ (s, $\operatorname{Ar} C), 126.6(\mathrm{~s}, \operatorname{Ar} C), 121.7(\mathrm{~s}, \operatorname{Ar} C), 121.3(\mathrm{~s}, \operatorname{Ar} C), 41.7\left(\mathrm{~s}, \mathrm{~W}=\mathrm{CC}\left(\mathrm{CH}_{3}\right)_{3}\right), 34.8(\mathrm{~s}, \operatorname{Ar}-$ $\left.C\left(\mathrm{CH}_{3}\right)_{3}\right), 31.7\left(\mathrm{~s}, \mathrm{~W}=\mathrm{CC}\left(\mathrm{CH}_{3}\right)_{3}\right), 30.4\left(\mathrm{~s}, \mathrm{Ar}-\mathrm{C}\left(\mathrm{CH}_{3}\right)_{3}\right)$. Red crystals from complex 2 were obtained from a $\mathrm{C}_{6} \mathrm{D}_{6}$ solution of the reaction mixture, washed with pentane and dried. Asymmetric unit contains one molecule of benzene. Yield (0.020 g, > 41\%) Elemental analysis calcd. (\%) for $\mathrm{C}_{42} \mathrm{H}_{50} \mathrm{O}_{5} \mathrm{~W}(818.70 \mathrm{~g} / \mathrm{mol})$ : C, 61.62; H, 6.16; Found: C 61.21, H 5.93. HRMS (ESI-MS) $\mathrm{m} / \mathrm{z}:[\mathrm{M}+\mathrm{H}]^{+}$Calcd for $\mathrm{C}_{36} \mathrm{H}_{45} \mathrm{WO}_{5}^{+}$741.2771; Found 741.2754. The remaining mixture of $\mathbf{2}$ and $\mathbf{3}$ was then heated up for 10 days at $70{ }^{\circ} \mathrm{C}$ to provide complex $\mathbf{3}$ in quantitative yield (Figure S12). $3{ }^{1} \mathrm{H}$ NMR $\left(\mathrm{C}_{6} \mathrm{D}_{6}, 500 \mathrm{MHz}\right) \delta(\mathrm{ppm}): \delta 7.39$ (d, 2H, Ar- $\left.H\right), 7.33(\mathrm{~d}, 2 \mathrm{H}, \mathrm{Ar}-$ $H), 7.26(\mathrm{~m}, 2 \mathrm{H}, \mathrm{Ar}-H), 7.17(\mathrm{~m}, 1 \mathrm{H}, \mathrm{Ar}-H), 6.86(\mathrm{~m}, 2 \mathrm{H}, \mathrm{Ar}-H), 1.71(\mathrm{~s}, 18 \mathrm{H}), 0.90(\mathrm{~s}, 9 \mathrm{H}) .{ }^{13} \mathrm{C}$ determined by ${ }^{1} \mathrm{H}-{ }^{13} \mathrm{C}$ gHSQC and gHMBC experiments: $\left(\mathrm{C}_{6} \mathrm{D}_{6}\right): \delta=280.9$ (s, W=C $\alpha$ ), 168.7 (s, $\operatorname{Ar} C), 147.6(\mathrm{~s}, \operatorname{Ar} C), 138.8(\mathrm{~s}, \operatorname{Ar} C), 131.8(\mathrm{~s}, \operatorname{Ar} C), 131.0(\mathrm{~s}, \operatorname{Ar} C), 129.1(\mathrm{~s}, \operatorname{Ar} C), 128.6(\mathrm{~s}$, $\operatorname{Ar} C), 126.5(\mathrm{~s}, \operatorname{Ar} C), 124.8(\mathrm{~s}, \operatorname{Ar} C), 119.6(\mathrm{~s}, \operatorname{Ar} C), 45.1\left(\mathrm{~s}, \mathrm{~W}=\mathrm{C} C\left(\mathrm{CH}_{3}\right)_{3}\right), 35.1$ (s, $\mathrm{Ar}-$ $\left.C\left(\mathrm{CH}_{3}\right)_{3}\right), 33.3\left(\mathrm{~s}, \mathrm{~W}=\mathrm{CC}\left(\mathrm{CH}_{3}\right)_{3}\right), 30.4\left(\mathrm{~s}, \mathrm{Ar}-\mathrm{C}\left(\mathrm{CH}_{3}\right)_{3}\right)$. HRMS (ESI-MS) m/z: $[\mathrm{M}+\mathrm{H}]^{+} \mathrm{Calcd}$ for $\mathrm{C}_{62} \mathrm{H}_{73} \mathrm{~W}_{2} \mathrm{O}_{6}^{+}$1281.4435; Found 1281.4415; m/z $[\mathrm{M}+2 \mathrm{H}]^{2+}$ Calcd for $\mathrm{C}_{62} \mathrm{H}_{74} \mathrm{~W}_{2} \mathrm{O}_{6}{ }^{2+}$ 641.2257; Found 641.2251.

\subsection{Synthesis of 2,3-Bis((menthyloxy)carbonyl)norbornadiene (BMCNBD)}

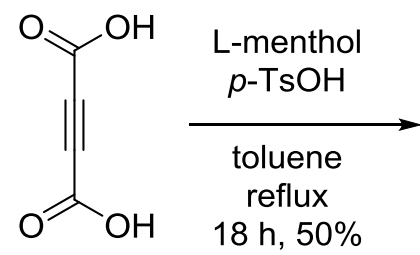

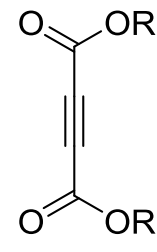

A

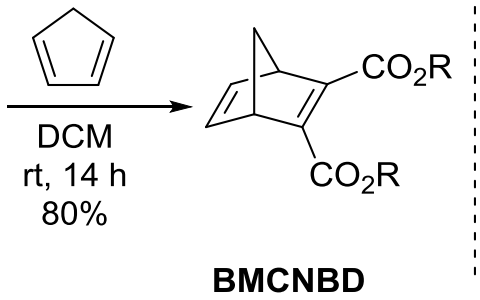

BMCNBD 
Acetylene dicarboxylic acid (1.00 g, $8.77 \mathrm{mmol})$, (-)-menthol (3.43 g, $21.9 \mathrm{mmol}, 2.50$ equiv), p-toluenesulfonic acid ( $0.167 \mathrm{mg}, 0.877 \mathrm{mmol}, 0.100$ equiv), and toluene (25 $\mathrm{mL})$ were charged in a round-bottomed flask equipped with a Dean-Stark apparatus. The solution was heated under reflux for $18 \mathrm{~h}$. The solution was cooled to $\mathrm{rt}$, washed with water $(20 \mathrm{~mL} \times 2)$ and brine $(20 \mathrm{~mL})$, dried $\left(\mathrm{Na}_{2} \mathrm{SO}_{4}\right)$, filtered, and concentrated, and the crude material was purified by column chromatography (hexanes:EtOAc $40: 1, R_{f}=0.2$ ) to give the product dimenthyl acetylenedicarboxylate $\mathbf{A}$ as a white solid (1.72 $\mathrm{g}, 4.40 \mathrm{mmol}, 50 \%)$. The spectral data were consistent with reported values. ${ }^{4}$

Freshly prepared cyclopentadiene $(0.42 \mathrm{~mL}, 5.1 \mathrm{mmol}, 2.0$ equiv) was added to a stirred solution of A (1.00 g, $2.56 \mathrm{mmol})$ in DCM (4 mL) at rt. After $14 \mathrm{~h}$ the solution was concentrated, and the crude material was purified by column chromatography (hexanes:EtOAc 20:1, $R_{f}=0.3$ ) and recrystallization $(\mathrm{MeOH})$ to give BMCNBD as a white solid (935 mg, $2.04 \mathrm{mmol}, 80 \%)$. The spectral data were consistent with reported values. ${ }^{5}$

\subsection{Polymerization of norbornene by catalyst 2}

To a $20 \mathrm{~mL}$ glass vial charged with norbornene $\left(0.038 \mathrm{~g}, 4.1 \times 10^{-4} \mathrm{~mol}, 100\right.$ equiv. $)$ in $1 \mathrm{~mL}$ of toluene were added $3 \mathrm{~mL}$ of a $1 \mathrm{mg} / \mathrm{mL}$ solution of 2 in toluene $\left(3 \mathrm{mg}, 4.1 \times 10^{-6} \mathrm{~mol}, 1\right.$ equiv.). The reaction was allowed to stir for $7 \mathrm{~h}$ at room temperature. After this period the reaction vessel was brought outside the glovebox and the reaction mixture was added dropwise to stirring methanol. Polynorbornene precipitates out and is isolated by filtration, and dried overnight under vacuum. Yield $(0.035 \mathrm{~g}, 92 \%) .{ }^{1} \mathrm{H}$ and ${ }^{13} \mathrm{C}$ NMR spectral assignments were consistent with literature reports. ${ }^{6}$

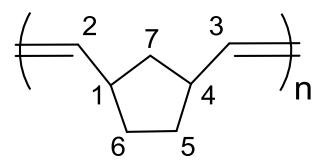




\subsection{Polymerization of norbornene by catalyst 3}

To a $20 \mathrm{~mL}$ glass vial charged with norbornene $\left(0.019 \mathrm{~g}, 2.0 \times 10^{-4} \mathrm{~mol}, 100\right.$ equiv. $)$ in $1 \mathrm{~mL}$ of toluene was added $3\left(2.6 \mathrm{mg}, 2.0 \times 10^{-6}\right.$ mol, 1 equiv.) in $1 \mathrm{~mL}$ of toluene. The reaction was allowed to stir for $7 \mathrm{~h}$ at room temperature. After this period the reaction vessel was brought outside the glovebox and the reaction mixture was added dropwise to stirring methanol. Polynorbornene precipitates out and is isolated by filtration, and dried overnight under vacuum. Yield (0.008 g, 42\%). A mixture of cis and trans polynorbornene was obtained. Tacticity was not determined. ${ }^{1} \mathrm{H}$ NMR spectral assignments were consistent with literature reports. ${ }^{5}$

\subsection{Polymerization of norbornene by catalyst 4}

A solution of norbornene $\left(0.580 \mathrm{~g}, 6.16 \times 10^{-3} \mathrm{~mol}, 1000\right.$ equiv. $)$ in $30 \mathrm{~mL}$ of THF was added to a $100 \mathrm{~mL}$ round bottom flask containing a stirring bar. This solution was cooled to $-40{ }^{\circ} \mathrm{C}$ and 50 $\mu \mathrm{L}$ of a stock solution $(0.039 \mathrm{~g}$ in $0.5 \mathrm{~mL}$ of THF $)$ of complex $4\left(6.15 \times 10^{-6} \mathrm{~mol}, 1\right.$ equiv. $)$ were added to it. The reaction was allowed to stir for $1 \mathrm{~h}$ at $-40{ }^{\circ} \mathrm{C}$. After this period $0.1 \mathrm{~mL}$ of ethyl vinyl ether was used to quench the reaction, which was then added dropwise to stirring methanol. Polynorbornene precipitates out and is isolated by filtration, and dried under vacuum. Yield (0.221 g, 38\%). ${ }^{1} \mathrm{H}$ and ${ }^{13} \mathrm{C}$ NMR spectral assignments were consistent with literature reports. ${ }^{6}$

\subsection{Polymerization of BMCNBD by catalyst 2}

Complex $2\left(0.016 \mathrm{~g}, 2.2 \times 10^{-5} \mathrm{~mol}, 1\right.$ equiv. $)$ was added to BMCNBD $\left(0.100 \mathrm{~g}, 2.2 \times 10^{-4} \mathrm{~mol}, 10\right.$ equiv.) in toluene $(2.2 \mathrm{~mL})$ contained in a $20 \mathrm{~mL}$ vial. The reaction was allowed to stir for $24 \mathrm{~h}$ at room temperature, and quenched outside the glovebox by adding the reaction mixture to stirring methanol. A suspension is formed. Poly(BMCNBD) is isolated by centrifugation. Yield (4 mg, 4\%). ${ }^{1} \mathrm{H}$ and ${ }^{13} \mathrm{C}$ NMR spectral assignments were consistent with literature reports. ${ }^{6}$ 
3. NMR Spectroscopic data for 2,3 , BMCNBD, poly(NBE) and poly(BMCNBD)

\subsection{NMR spectra of complex 2 and 3}

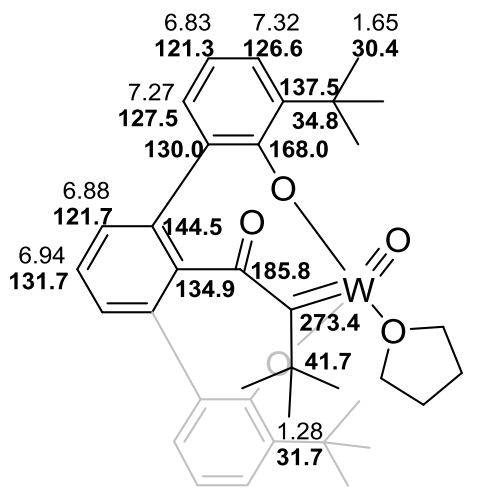

2

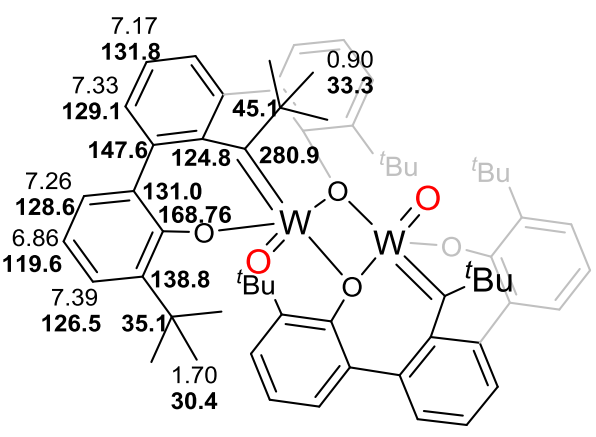

3

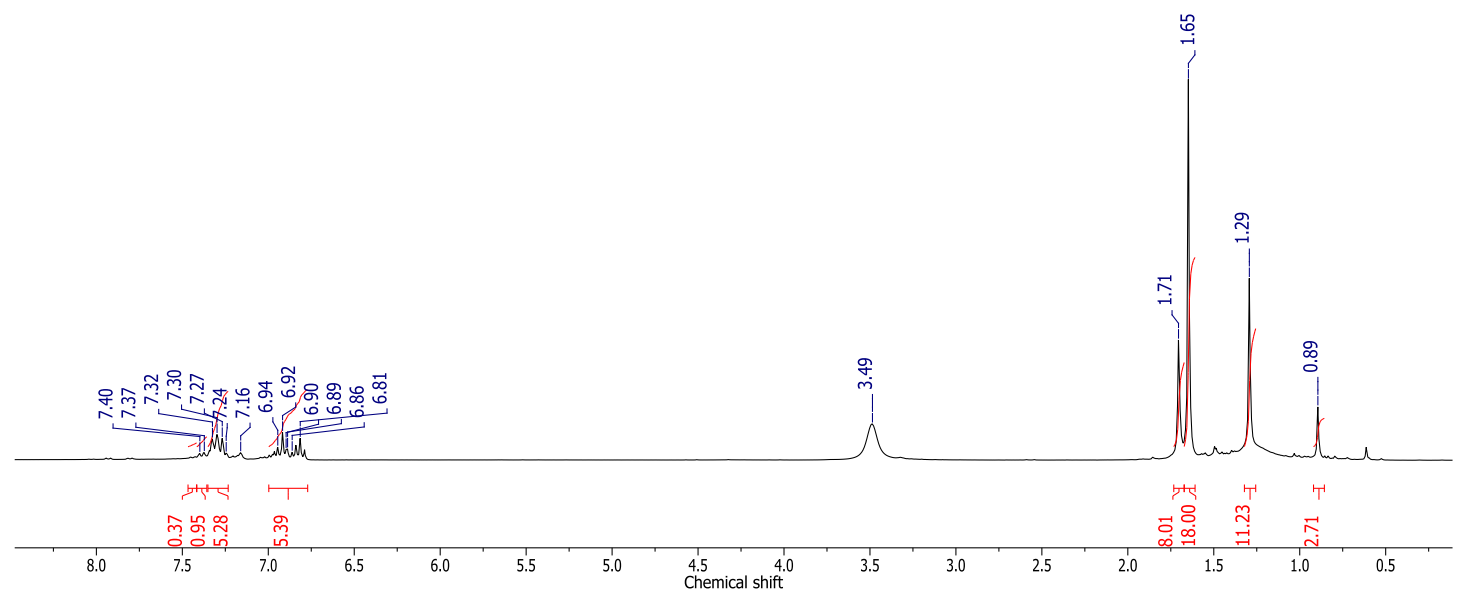

Figure S1. ${ }^{1} \mathrm{H}$ NMR spectrum of $\mathbf{2}$ and $\mathbf{3}$ in $\mathrm{C}_{6} \mathrm{D}_{6}$. 


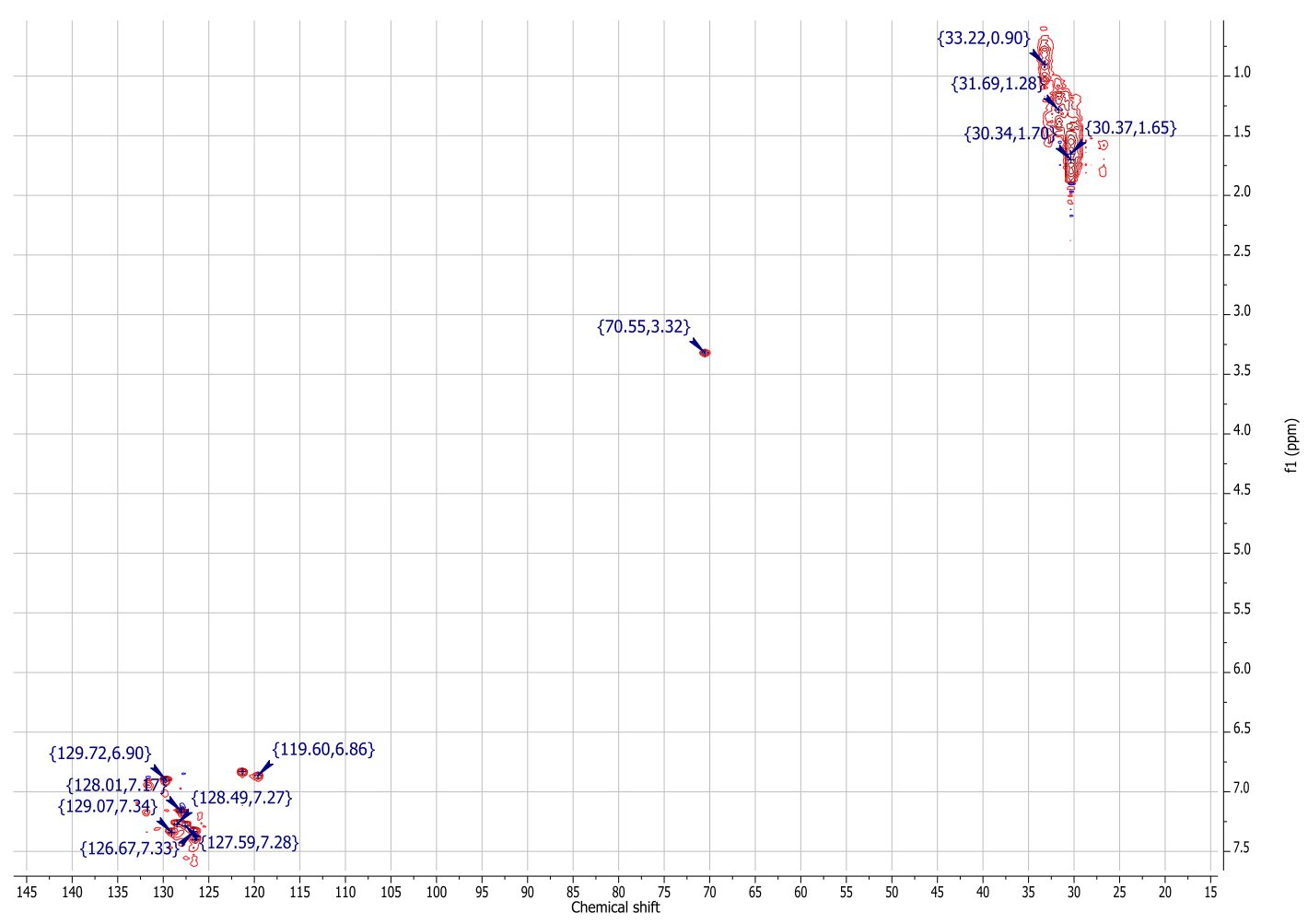

Figure S2. ${ }^{1} \mathrm{H}^{-13} \mathrm{C}$ gHSQC NMR spectrum of $\mathbf{2}$ and $\mathbf{3}$ in $\mathrm{C}_{6} \mathrm{D}_{6}$.

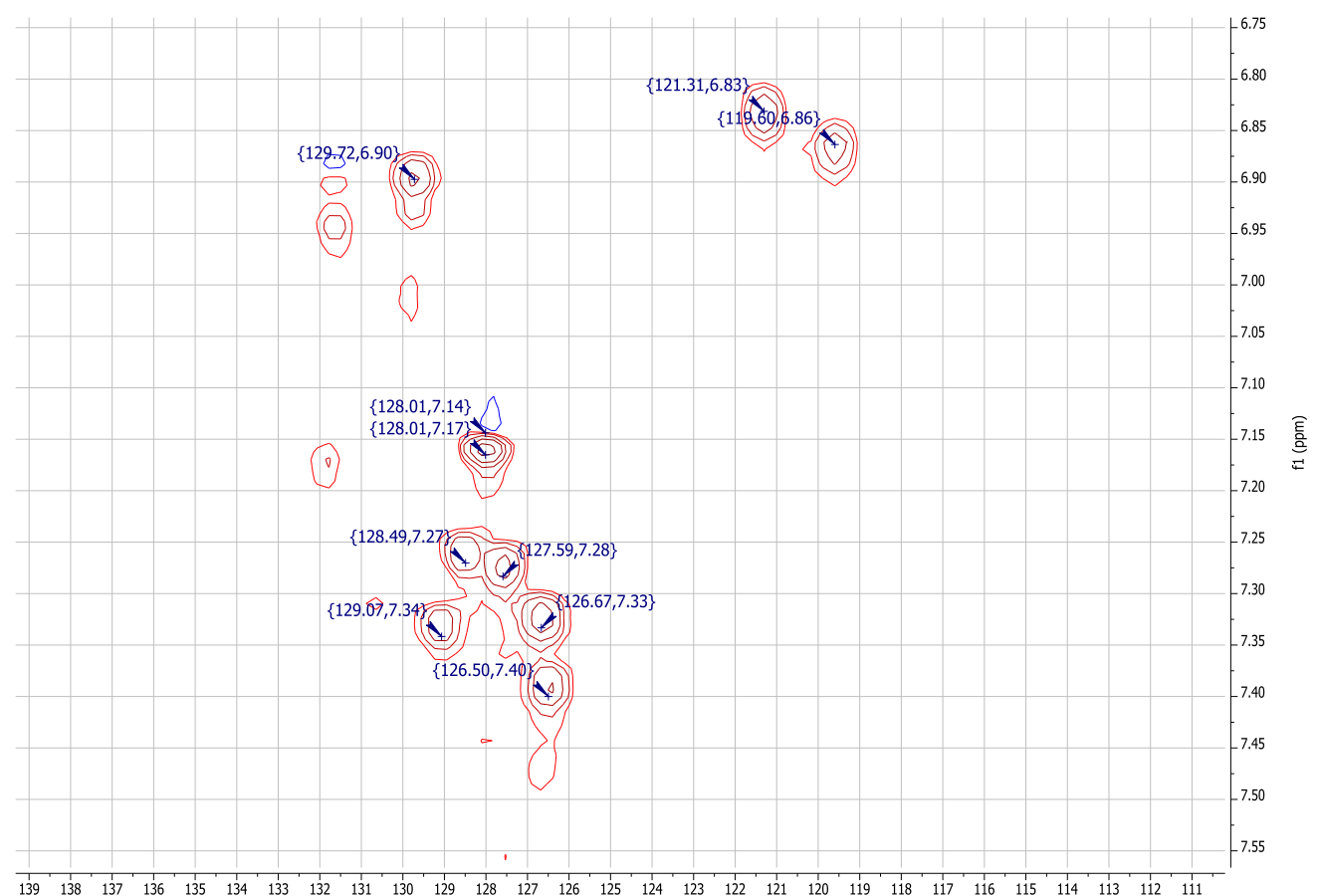

Figure S3. Expansion of ${ }^{1} \mathrm{H}_{-}{ }^{13} \mathrm{C}$ gHSQC NMR spectrum of $\mathbf{2}$ and $\mathbf{3}$ in $\mathrm{C}_{6} \mathrm{D}_{6}$. 


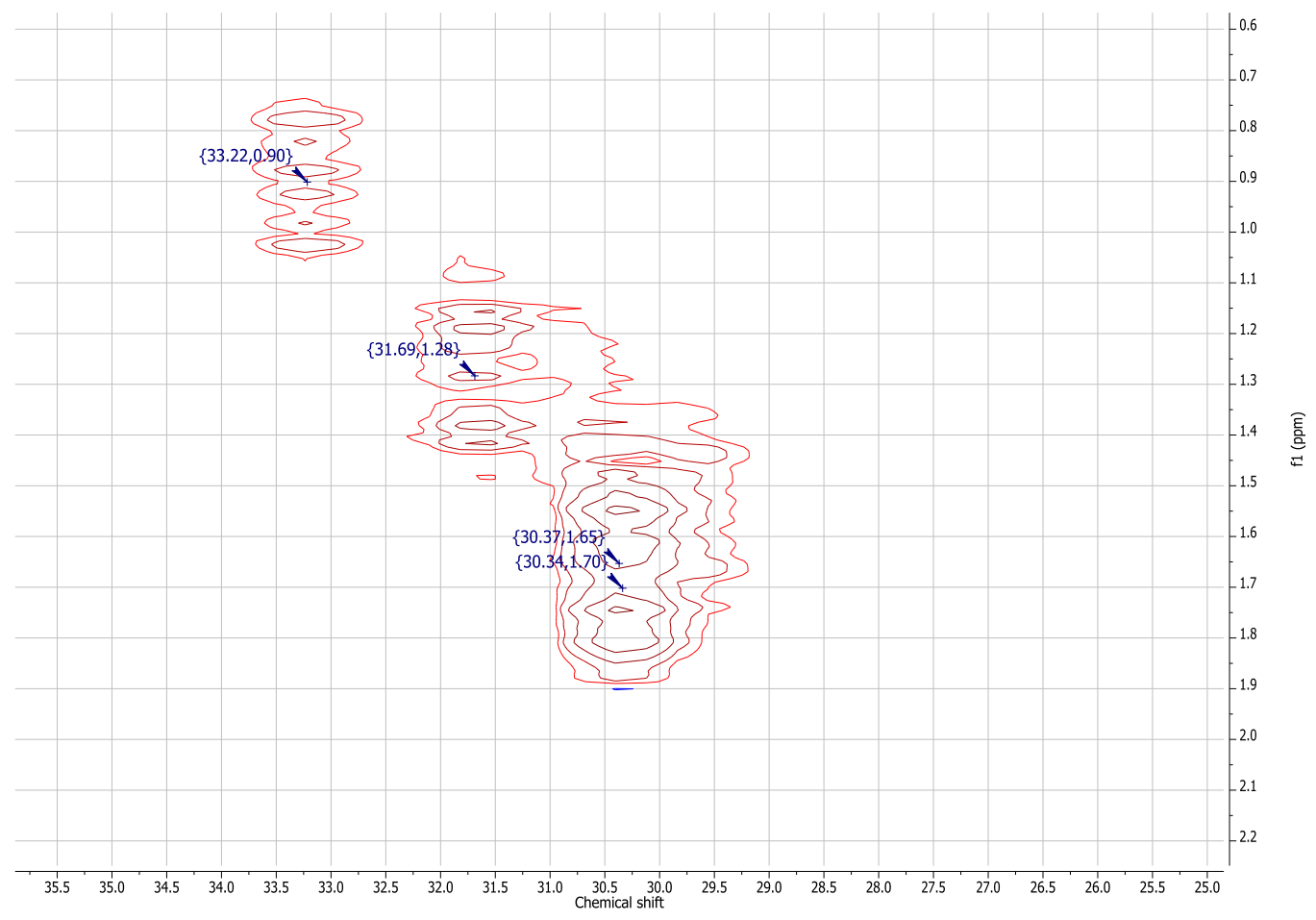

Figure S4. Expansion of ${ }^{1} \mathrm{H}_{-}{ }^{13} \mathrm{C}$ gHSQC NMR spectrum of $\mathbf{2}$ and $\mathbf{3}$ in $\mathrm{C}_{6} \mathrm{D}_{6}$.

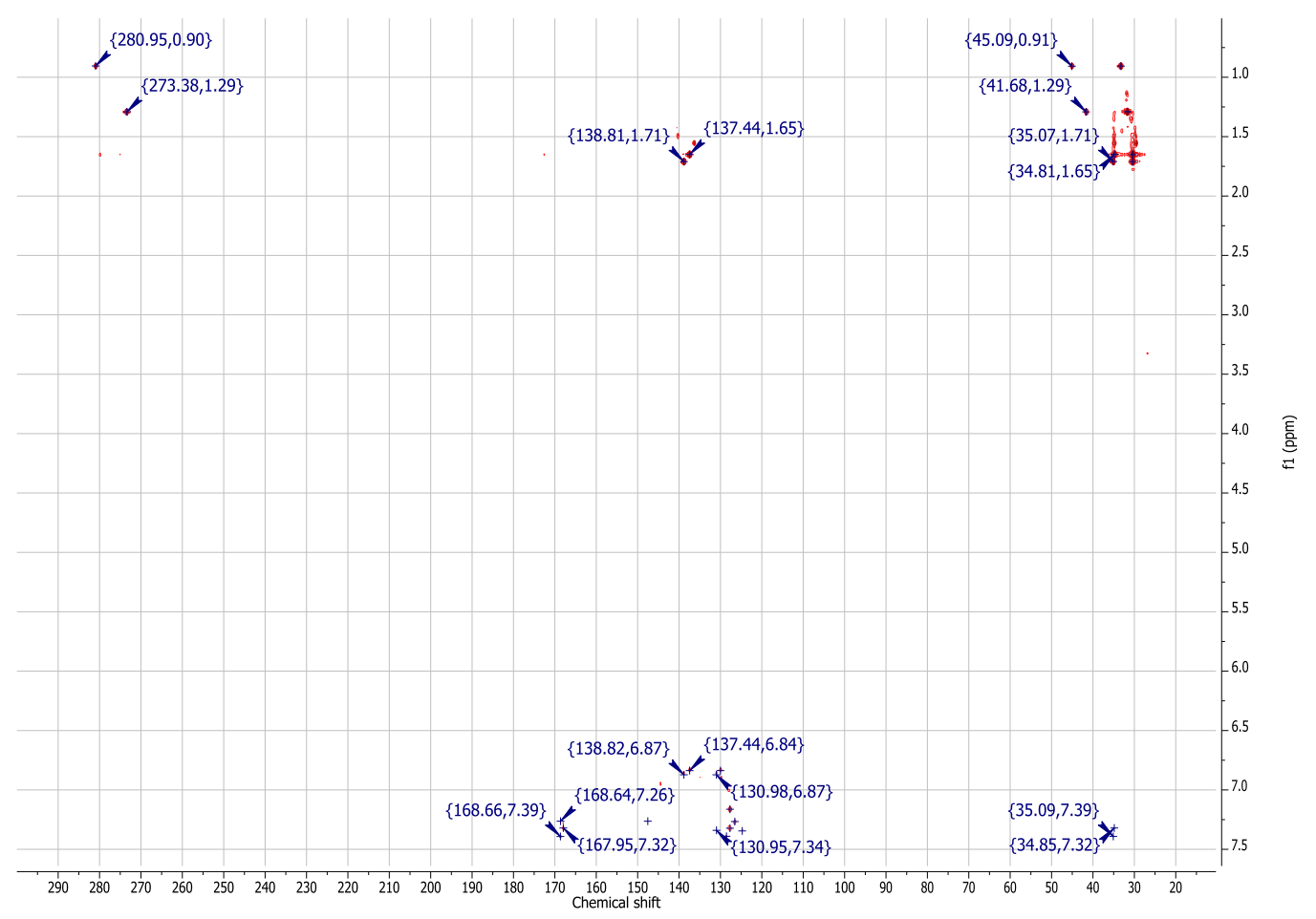

Figure S5. ${ }^{1} \mathrm{H}-{ }^{13} \mathrm{C}$ gHMBC NMR spectrum of $\mathbf{2}$ and $\mathbf{3}$ in $\mathrm{C}_{6} \mathrm{D}_{6}$. 


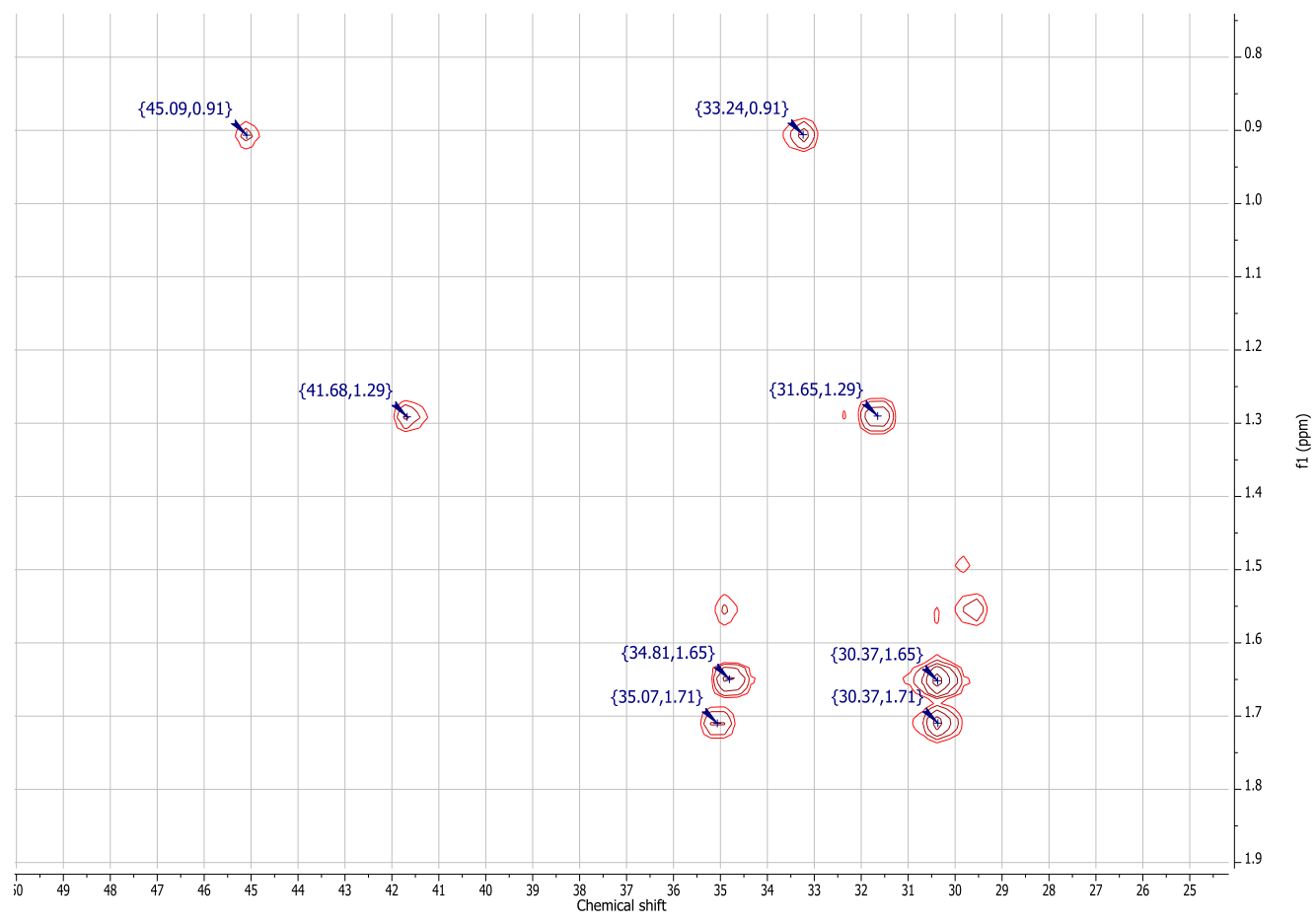

Figure S6. Expansion of ${ }^{1} \mathrm{H}-{ }^{13} \mathrm{C}$ gHMBC NMR spectrum of 2 and 3 in $\mathrm{C}_{6} \mathrm{D}_{6}$.

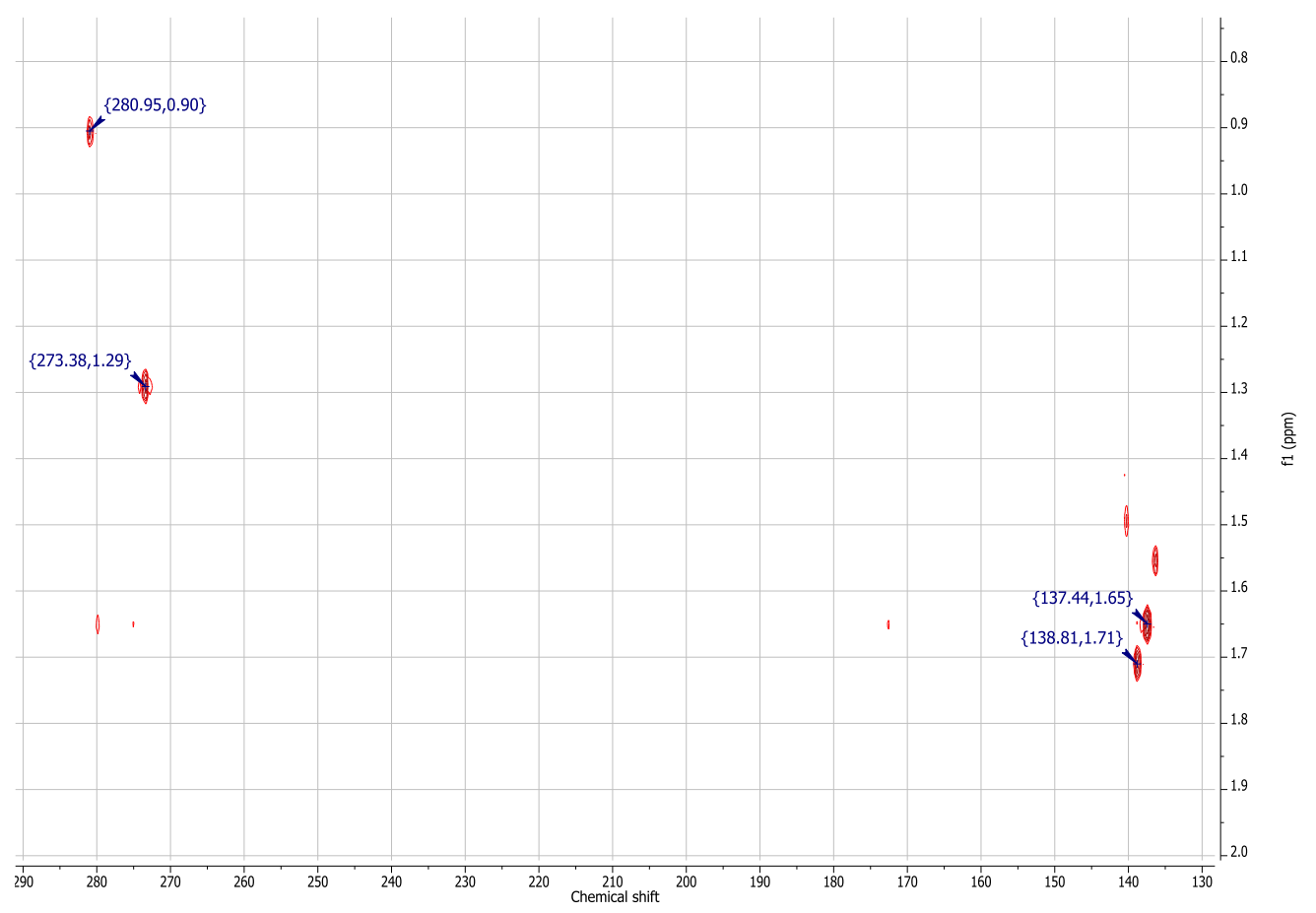

Figure S7. Expansion of ${ }^{1} \mathrm{H}^{13} \mathrm{C}$ gHMBC NMR spectrum of $\mathbf{2}$ and $\mathbf{3}$ in $\mathrm{C}_{6} \mathrm{D}_{6}$. 


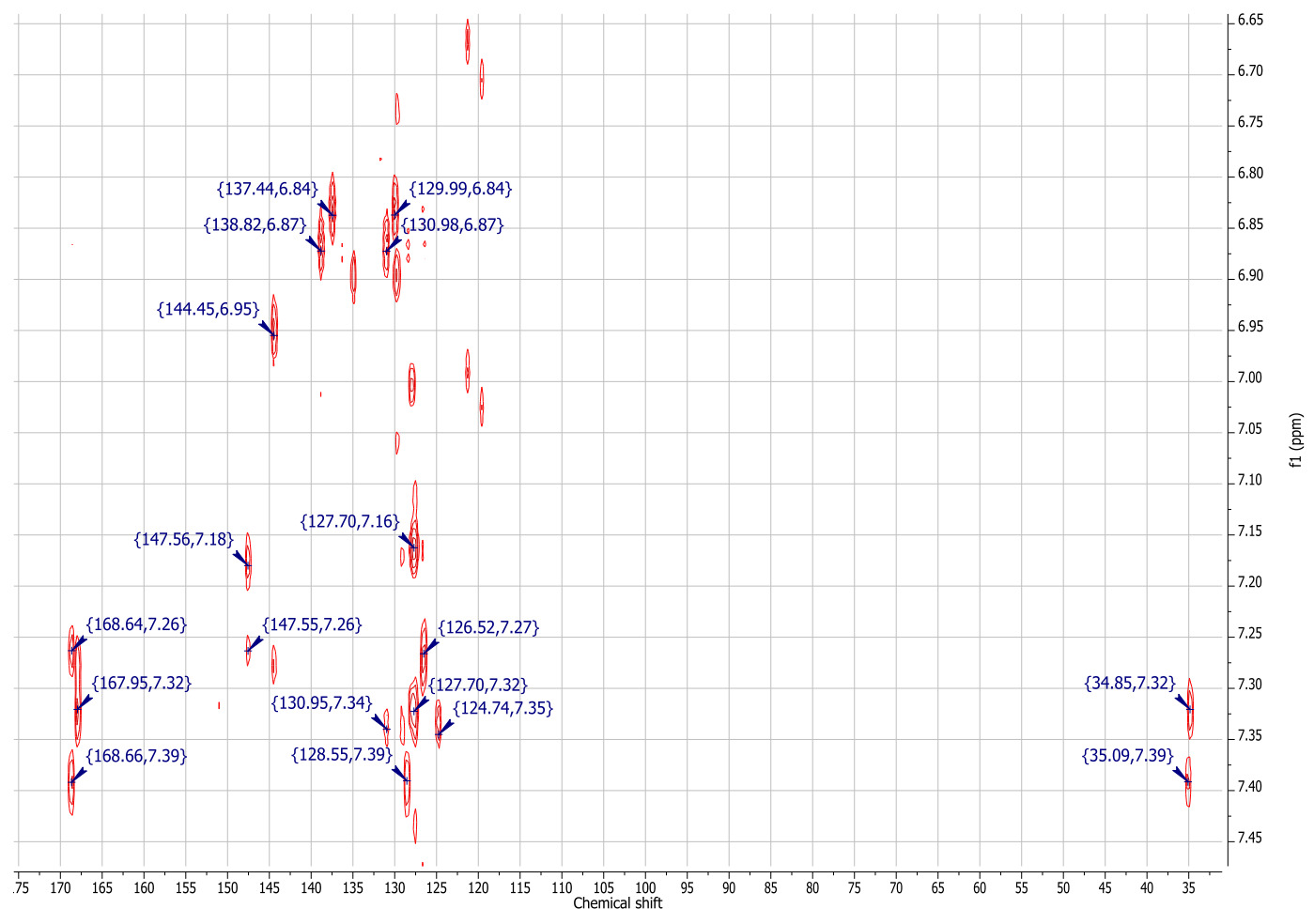

Figure S8. Expansion of ${ }^{1} \mathrm{H}^{13} \mathrm{C}$ gHMBC NMR spectrum of $\mathbf{2}$ and $\mathbf{3}$ in $\mathrm{C}_{6} \mathrm{D}_{6}$.

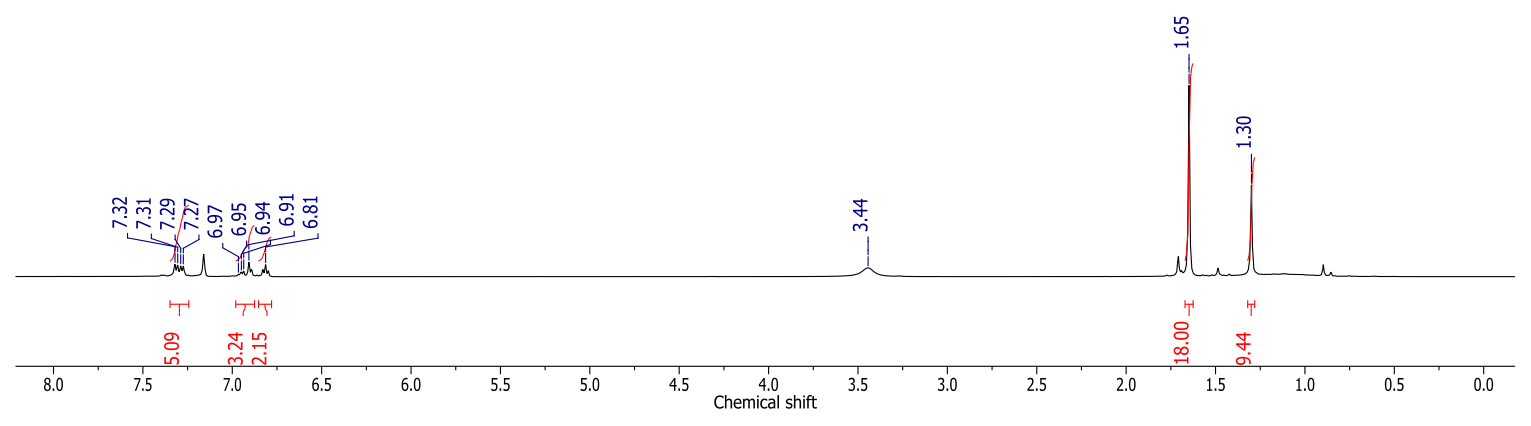

Figure S9. ${ }^{1} \mathrm{H}$ NMR spectrum of 2 in $\mathrm{C}_{6} \mathrm{D}_{6}$. 


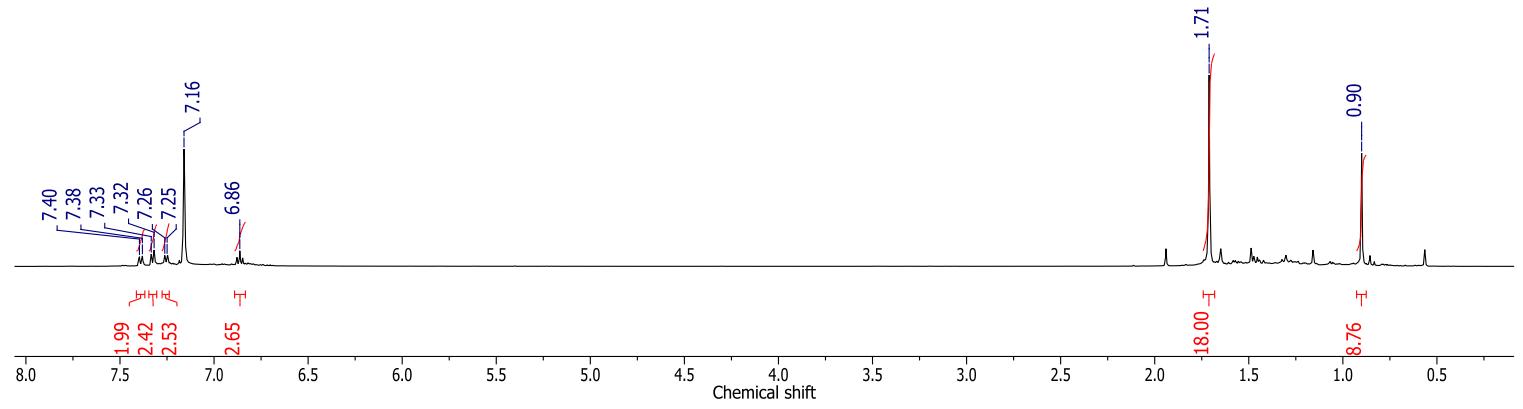

Figure S10. ${ }^{1} \mathrm{H}$ NMR spectrum of 3 in $\mathrm{C}_{6} \mathrm{D}_{6}$.

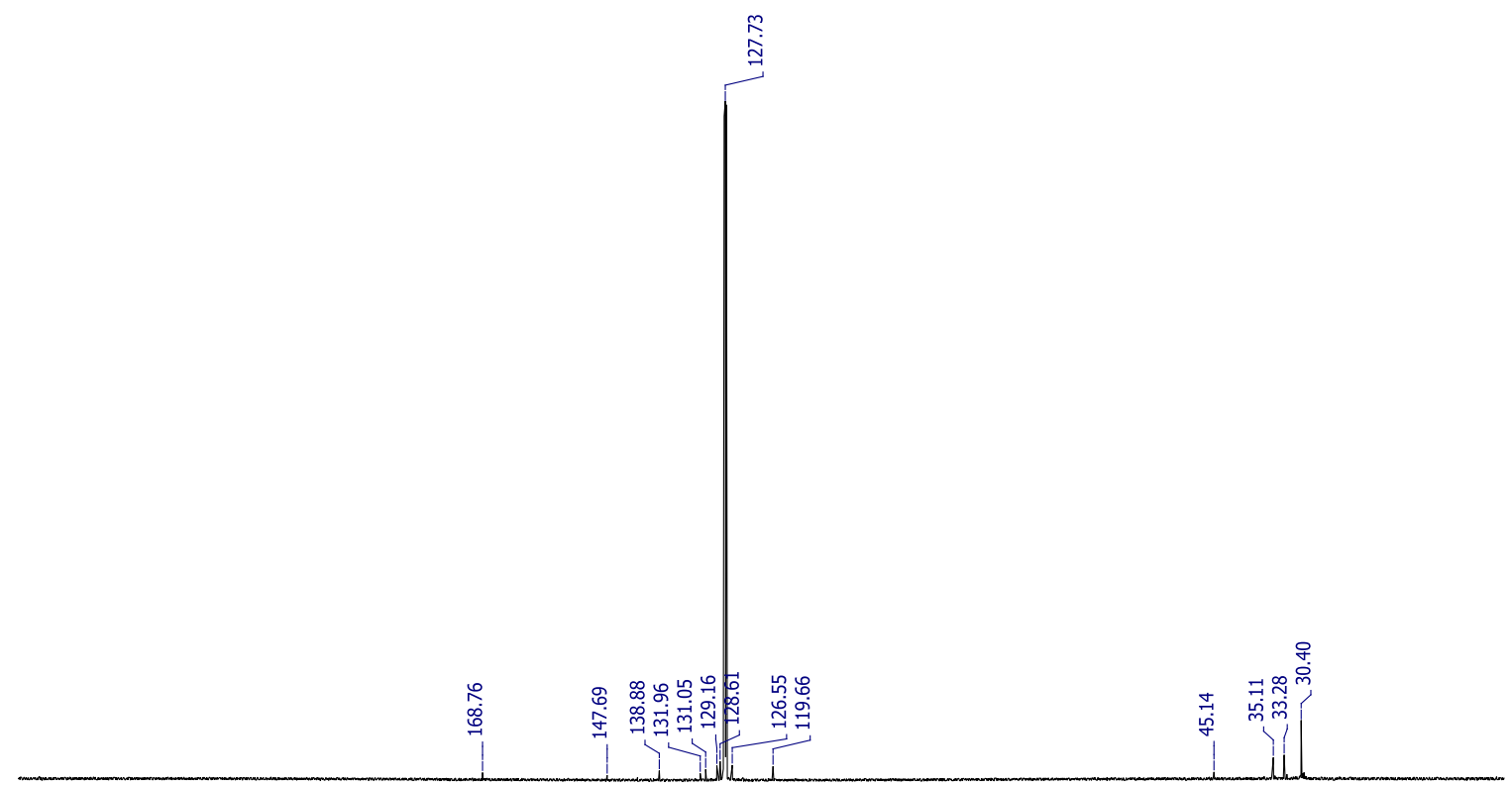

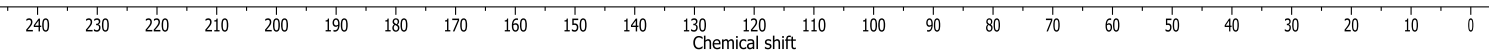

Figure S11. ${ }^{13} \mathrm{C}$ NMR spectrum of 3 in $\mathrm{C}_{6} \mathrm{D}_{6}$. 


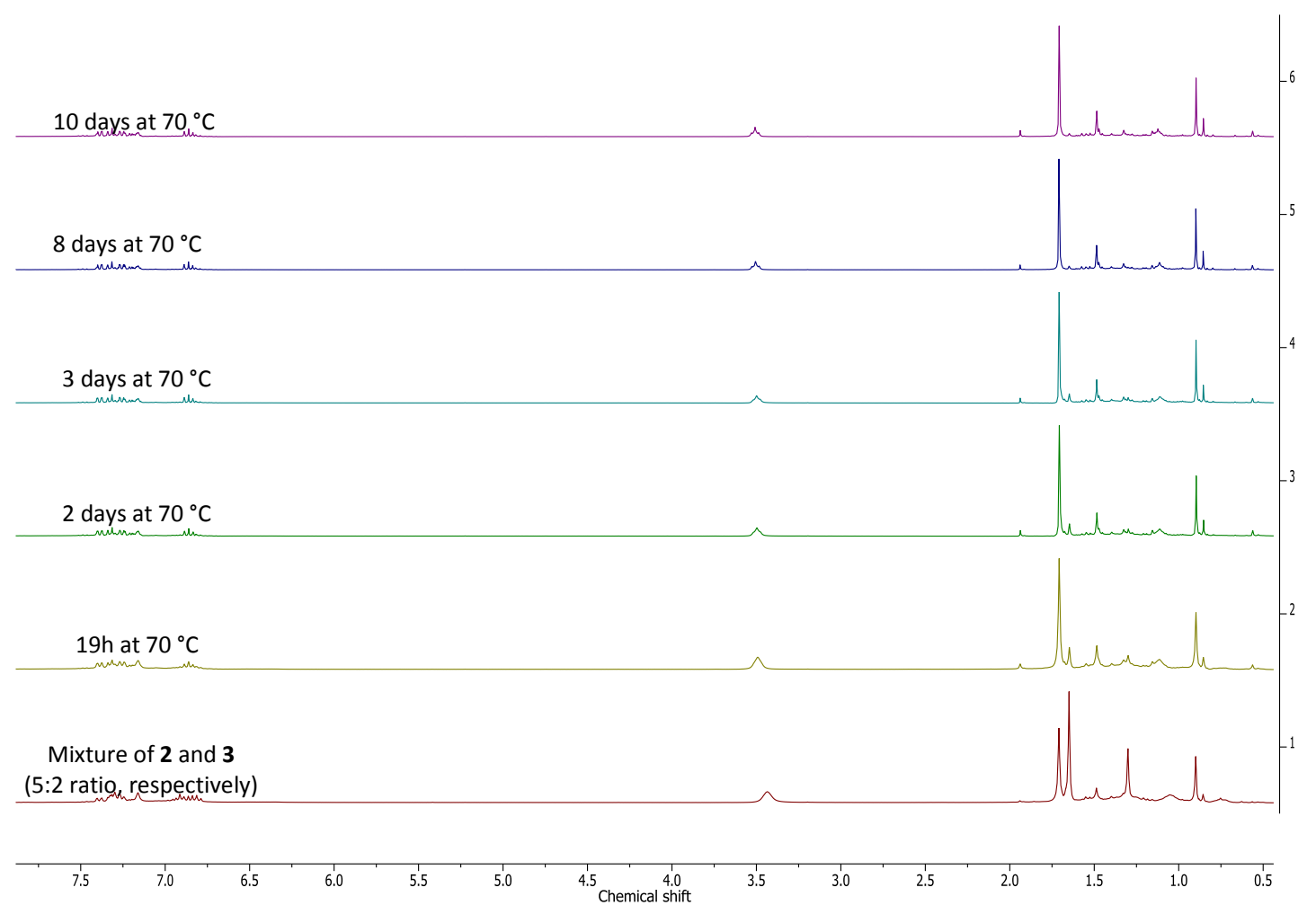

Figure S12. ${ }^{1} \mathrm{H}$ NMR spectra of mixture of $\mathbf{2}$ and $\mathbf{3}$ showing conversion of $\mathbf{2}$ into $\mathbf{3}$ after 10 days at $70{ }^{\circ} \mathrm{C}$, in $\mathrm{C}_{6} \mathrm{D}_{6}$. 


\subsection{NMR spectra of BMCNBD}
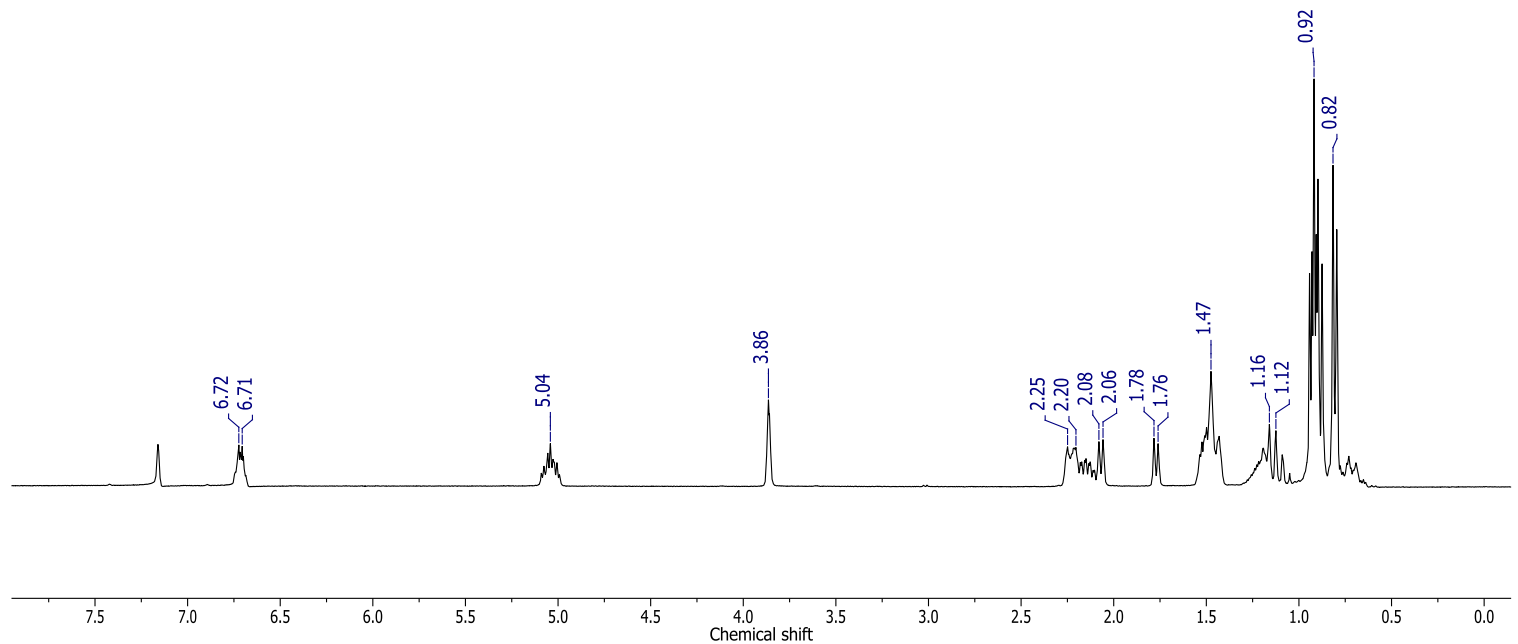

Figure S13. ${ }^{1} \mathrm{H}$ NMR spectrum of BMCNBD in $\mathrm{C}_{6} \mathrm{D}_{6}$.

\subsection{NMR spectra of poly(NBE) generated by 2}

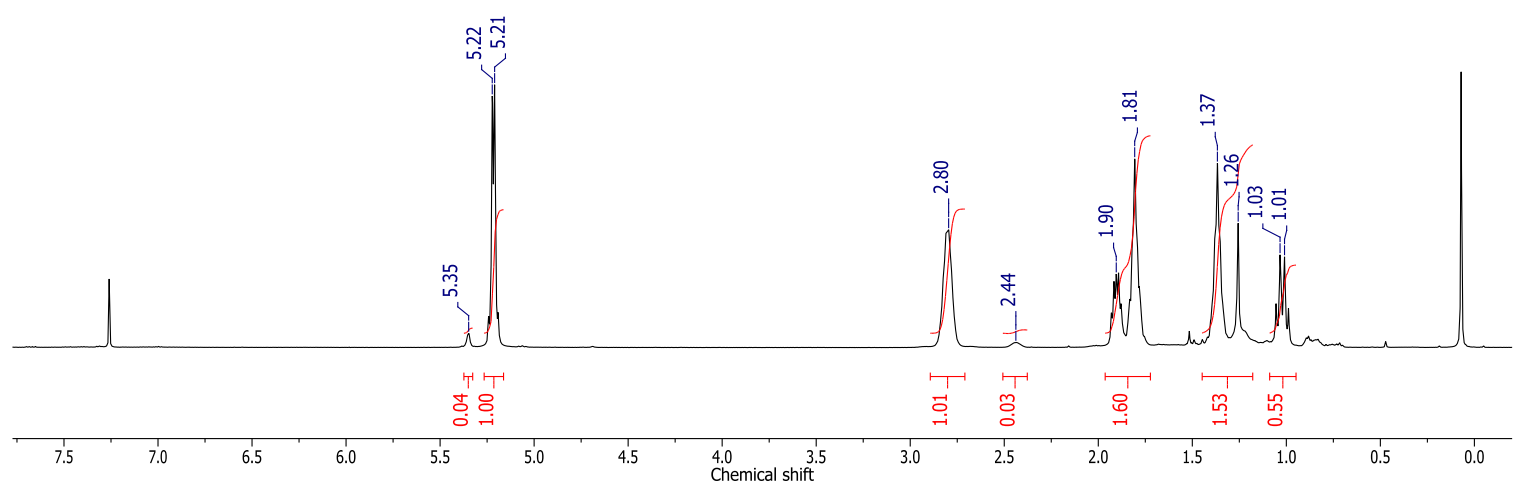

Figure S14. ${ }^{1} \mathrm{H}$ NMR spectrum of polynorbornene generated by $\mathbf{2}$, in $\mathrm{CDCl}_{3}$. 


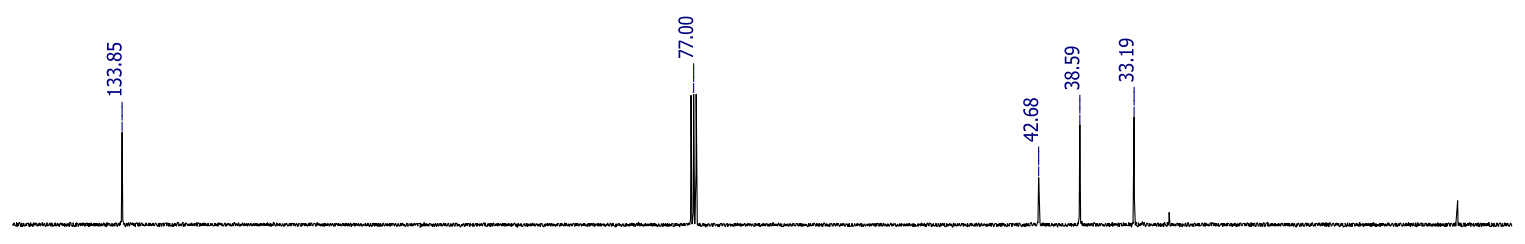

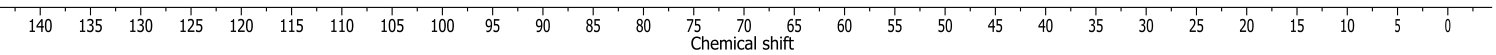

Figure S15. ${ }^{13} \mathrm{C}$ NMR spectrum of of polynorbornene generated by 2 , in $\mathrm{CDCl}_{3}$.

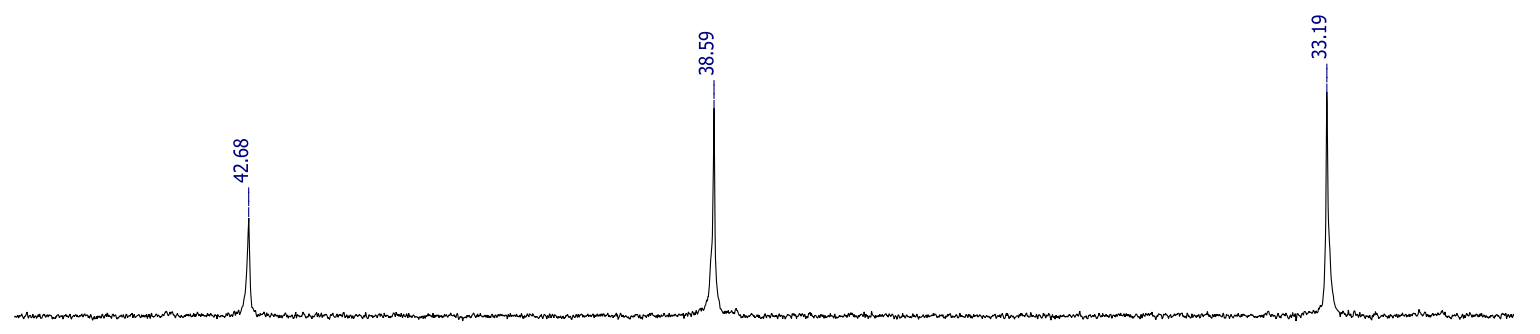

$\begin{array}{lllllllllllllllllllllllllllll}44.5 & 44.0 & 43.5 & 43.0 & 42.5 & 42.0 & 41.5 & 41.0 & 40.5 & 40.0 & 39.5 & 39.0 & 38.5 & 38.0 & 37.5 & 37.0 & 36.5 & 36.0 & 35.5 & 35.0 & 34.5 & 34.0 & 33.5 & 33.0 & 32.5 & 32.0\end{array}$ Figure S16. Expansion of ${ }^{13} \mathrm{C}$ NMR spectrum of of polynorbornene generated by $2(>98 \%$ syndiotactic), in $\mathrm{CDCl}_{3}$.
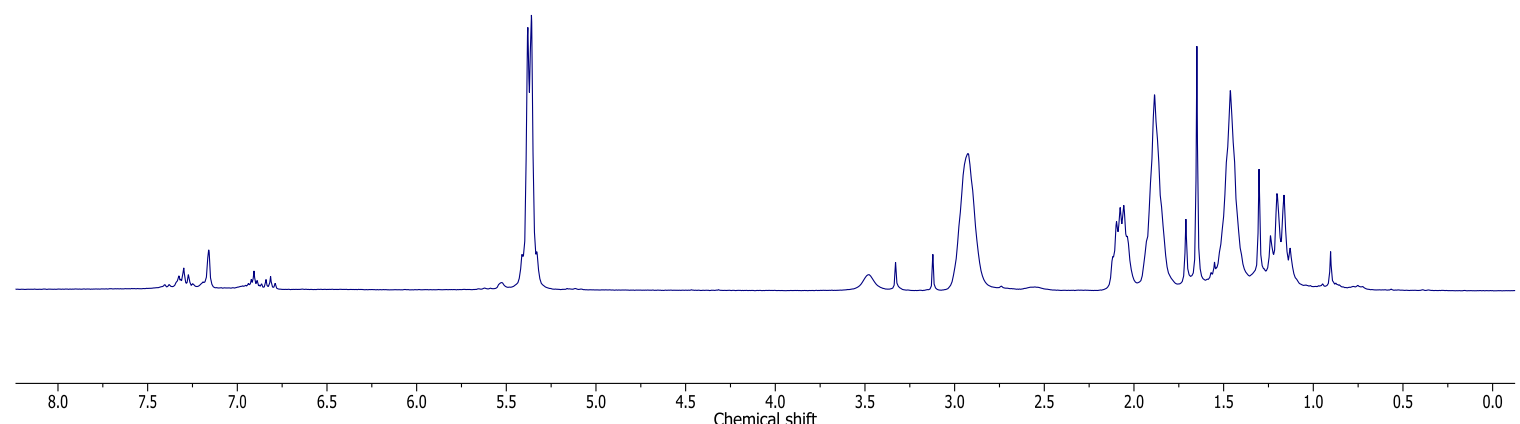

Figure S17. ${ }^{1} \mathrm{H}$ NMR spectra of polynorbornene generated by $\mathbf{2}$ in a 1:10 ratio, in a J-Young NMR tube, in $\mathrm{C}_{6} \mathrm{D}_{6}$.

\subsection{NMR spectra of poly(NBE) generated by 3}




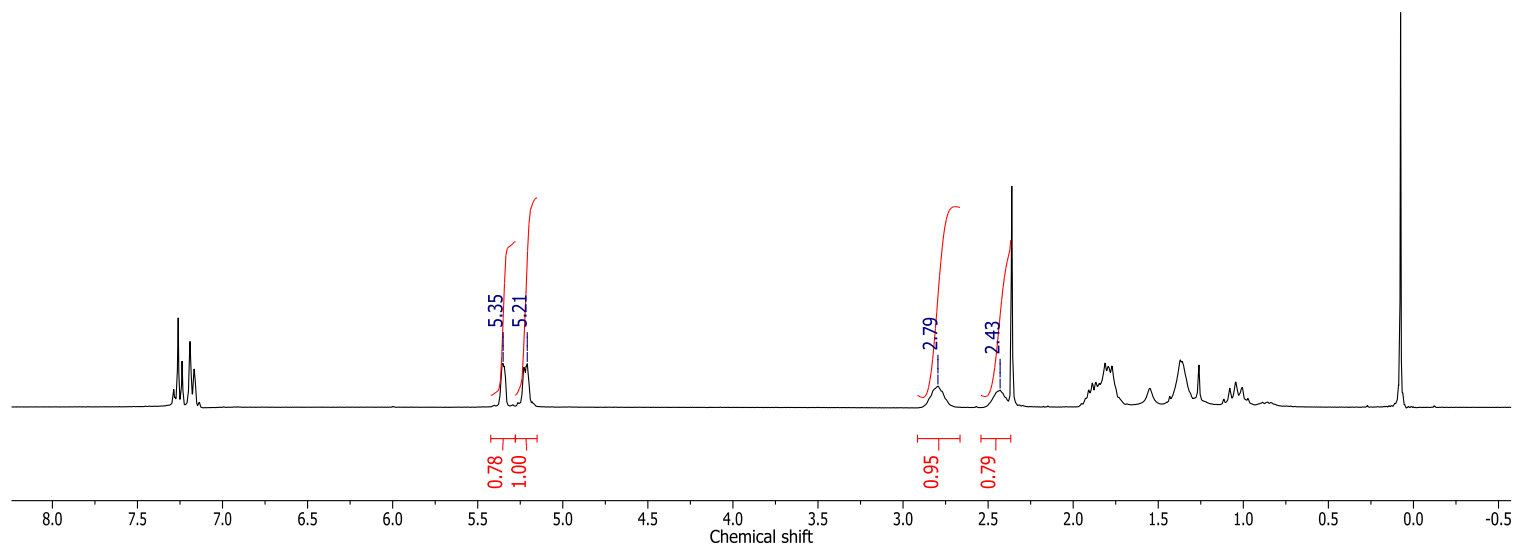

Figure S18. ${ }^{1} \mathrm{H}$ NMR spectrum of polynorbornene generated by 3 , in $\mathrm{CDCl}_{3}$.

\subsection{NMR spectra of poly(NBE) generated by 4}

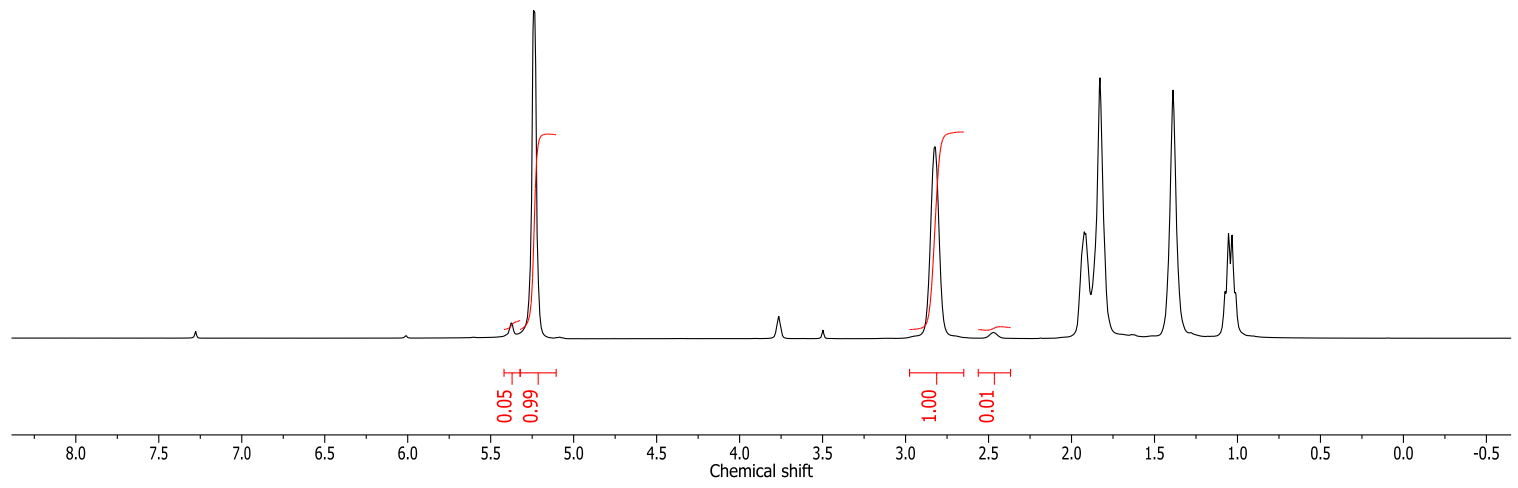

Figure S19. ${ }^{1} \mathrm{H}$ NMR spectrum of polynorbornene generated by 4 , in $\mathrm{CDCl}_{3}$.
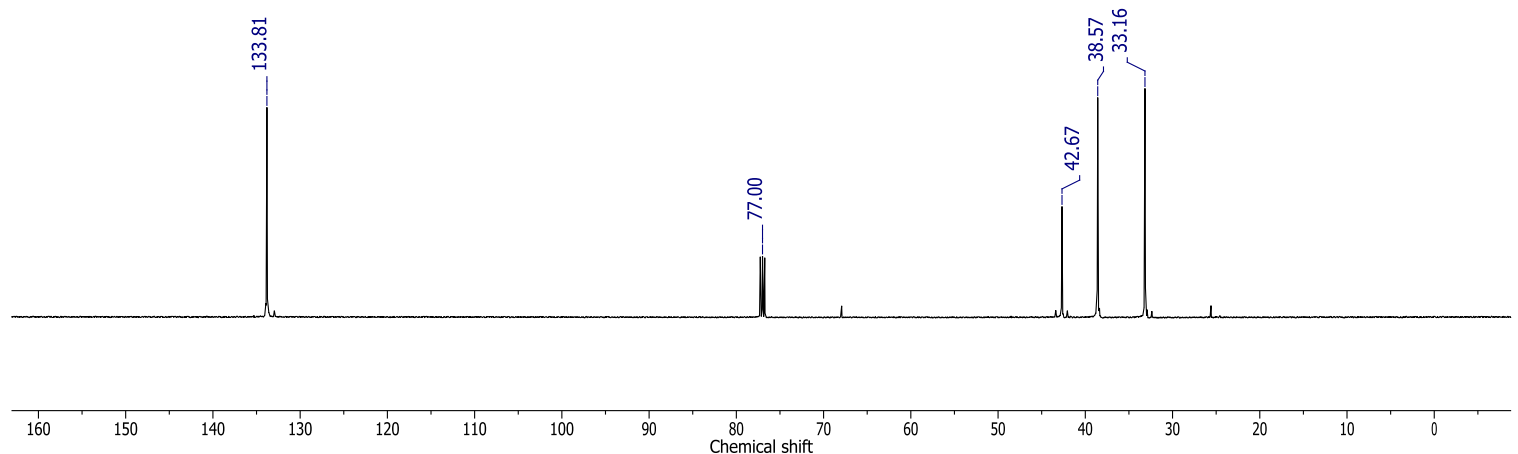

Figure S20. ${ }^{13} \mathrm{C}$ NMR spectrum of polynorbornene generated by 4 , in $\mathrm{CDCl}_{3}$. 


\subsection{NMR spectra of poly(BMCNBD) generated by 2}

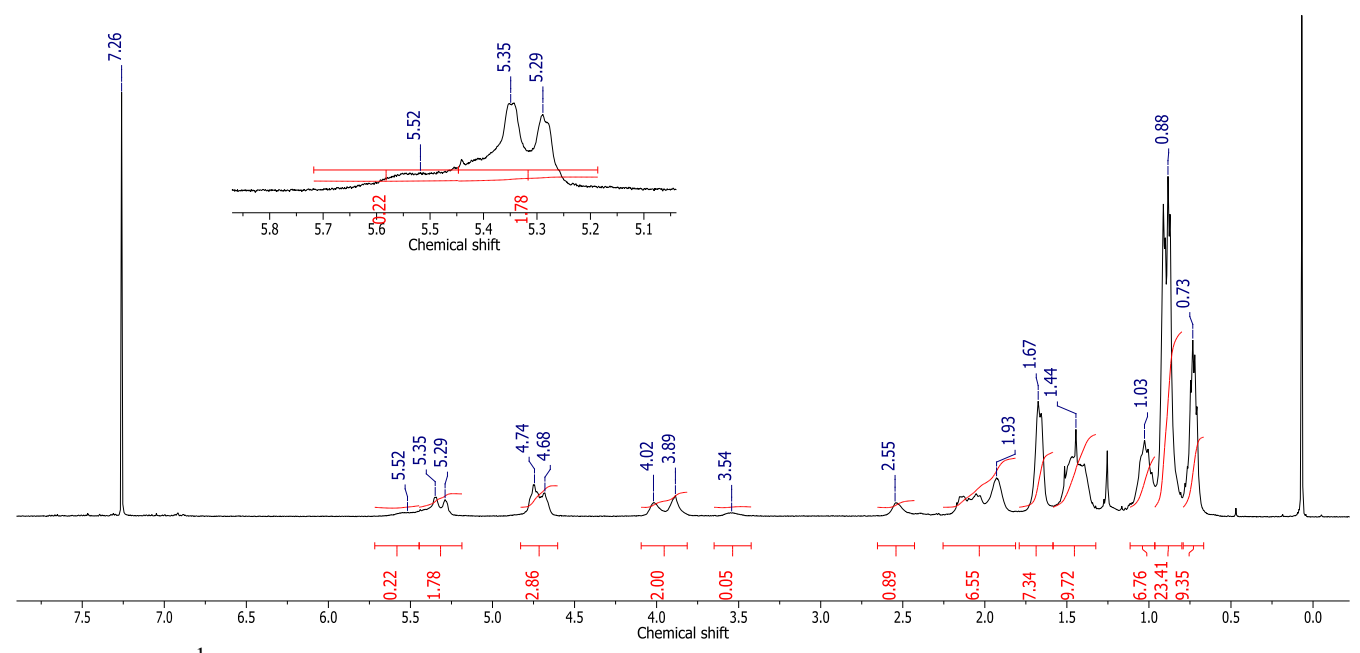

Figure S21. ${ }^{1} \mathrm{H}$ NMR spectrum of poly(BMCNBD) generated by 2 , in $\mathrm{CDCl}_{3}$.

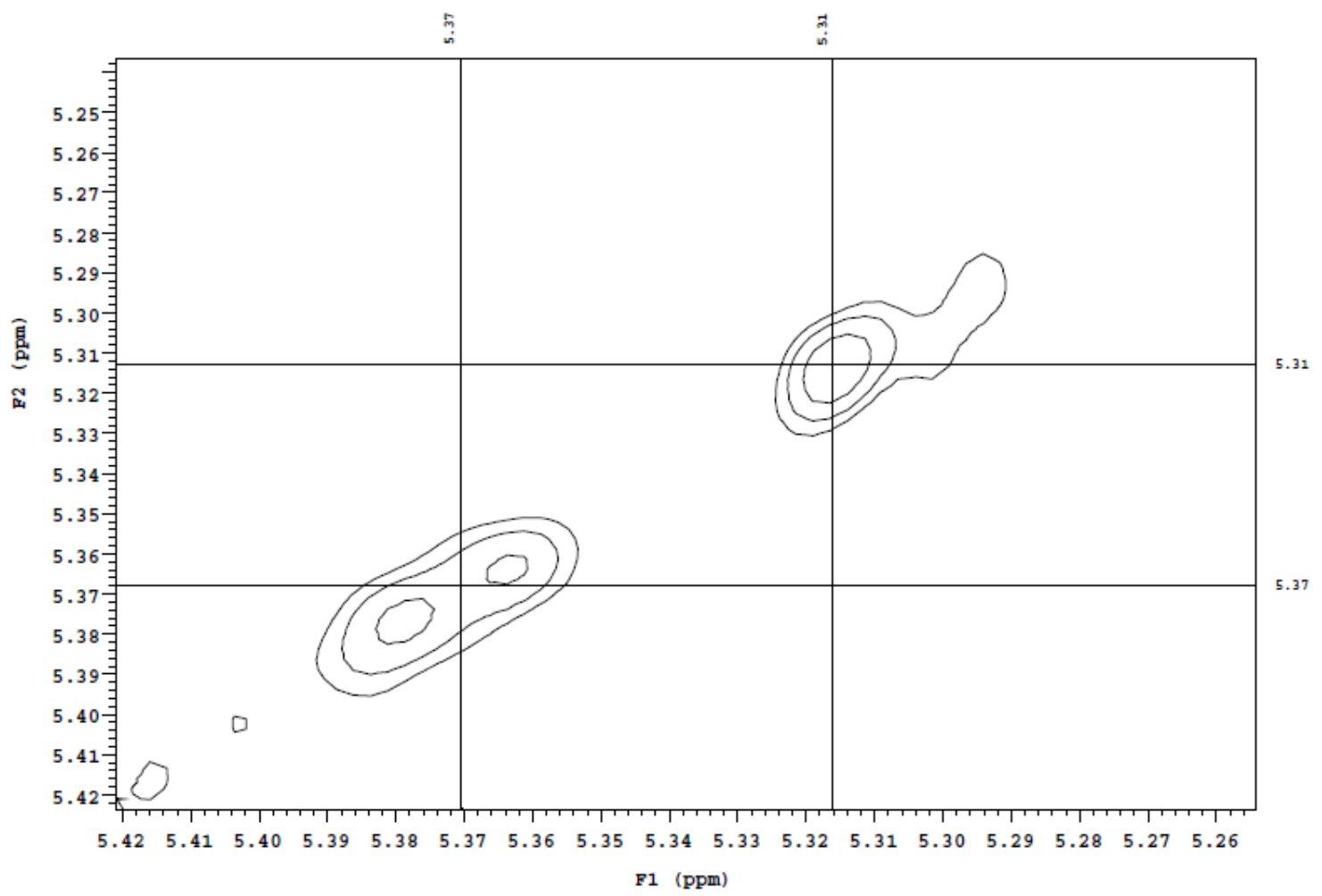

Figure S22. Olefinic proton region of ${ }^{1} \mathrm{H}-{ }^{1} \mathrm{H}$ COSY NMR of poly(BMCNBD) synthesized by 2 , in $\mathrm{CDCl}_{3}$.

\subsection{NMR spectrum of partially brominated poly(NBE)}




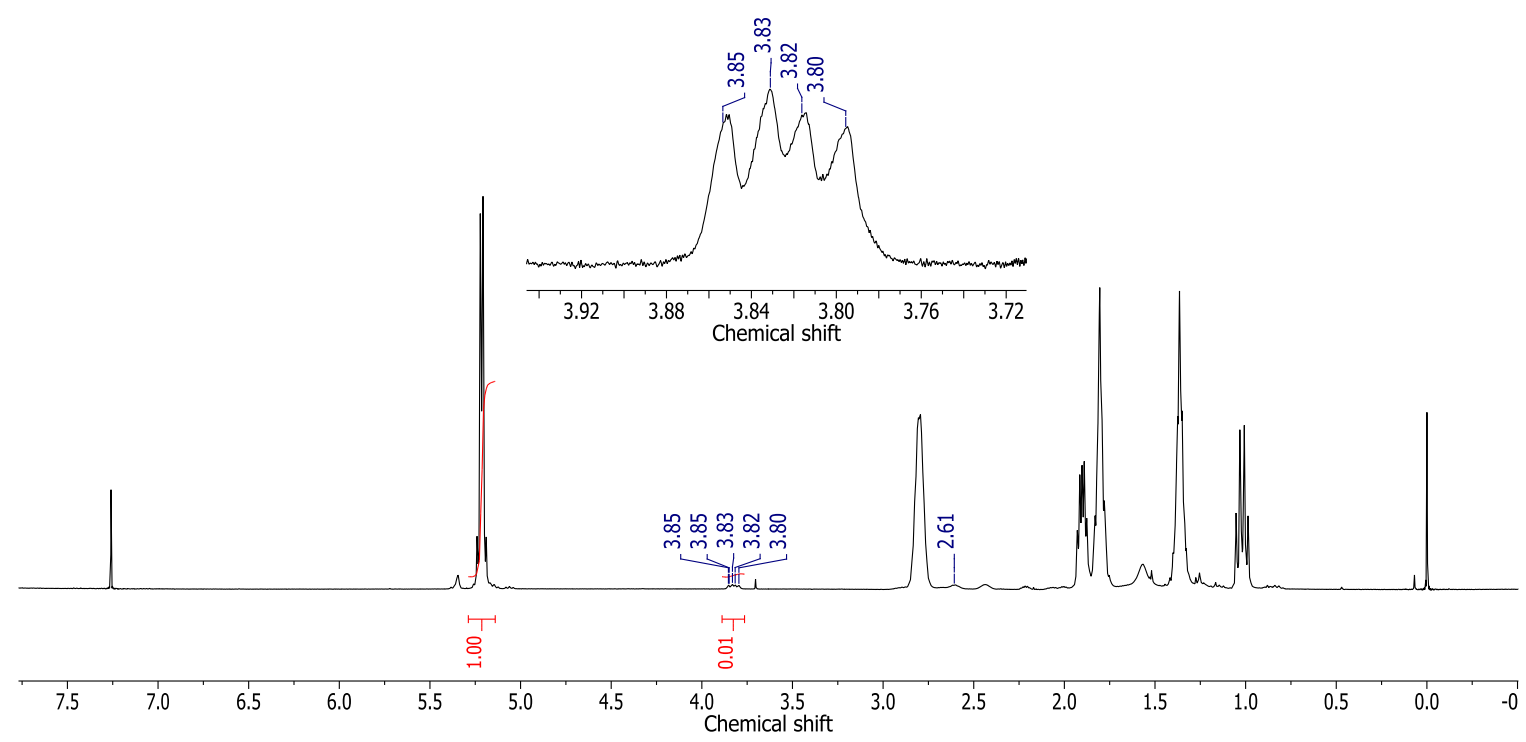

Figure S23. ${ }^{1} \mathrm{H}$ NMR of partially $(\approx 1 \%)$ brominated cis, syndiotactic polynorbornene generated by $\mathbf{2}$, in $\mathrm{CDCl}_{3}$.

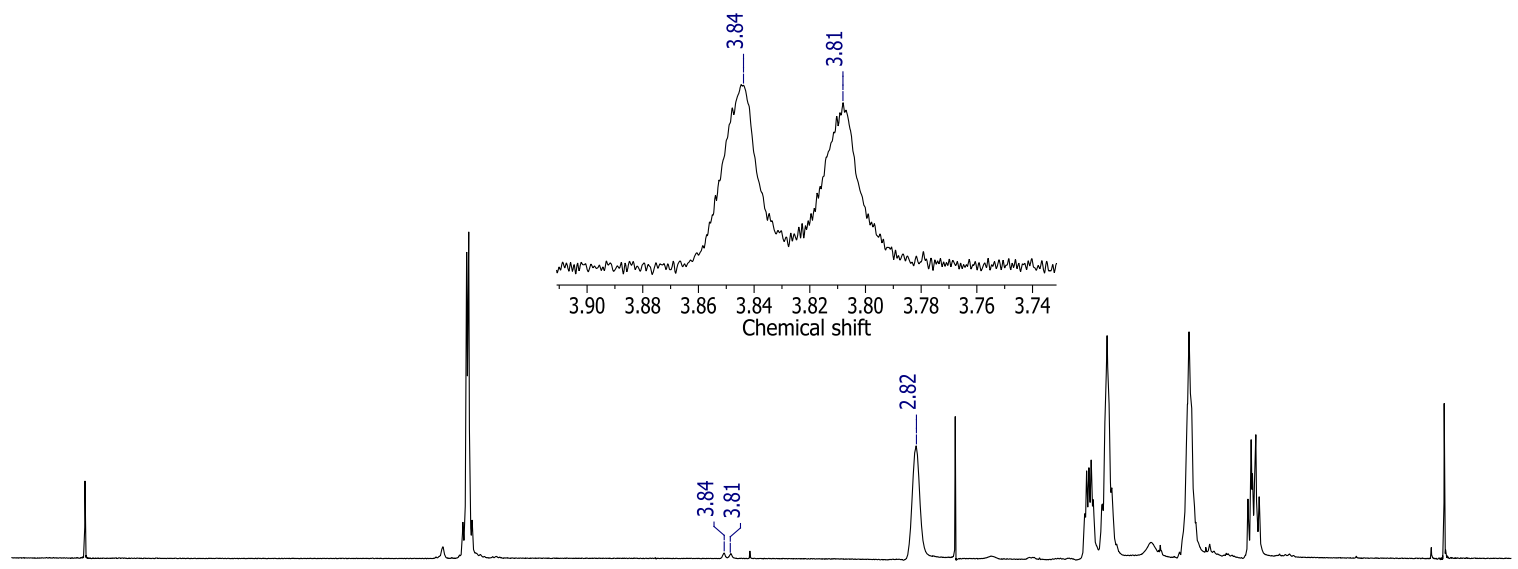

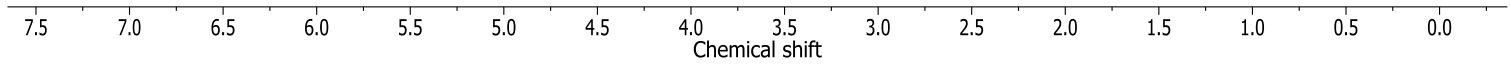

Figure S24. ${ }^{1} \mathrm{H}$ NMR of partially $(\approx 1 \%)$ brominated cis, syndiotactic polynorbornene generated by $\mathbf{2}$, in $\mathrm{CDCl}_{3}$, with decoupling of the methine protons at $2.61 \mathrm{ppm}$.

\section{Gas Chromatography/Electron Ionization-Mass Spectrometry (GC/EI-MS)}

$1 \mathrm{~mL}$ of a benzene solution containing $\mathbf{2}$ and $\mathbf{3}$, and $5 \mu \mathrm{L}$ of DCM as internal standard was placed in a glass vial equipped a septum screw cap. A blank sample $(1 \mathrm{~mL}$ of benzene and $5 \mu \mathrm{L}$ of 
DCM) was also prepared and placed on a same size vial with septum screw cap. Both vials were sealed and heated to $80^{\circ} \mathrm{C}$ for $36 \mathrm{~h}$ (in order to convert $\mathbf{2}$ into $\mathbf{3}$, with release of $\mathrm{CO}$ ).

The headspace $(100 \mu \mathrm{L})$ of the blank and the sample were analyzed via split injection GC/EI-MS with $35^{\circ} \mathrm{C}$ isothermal separation. The results of the headspace analyses are shown in the Table 1 .

Table S1. Headspace GC/EI-MS areas and relative areas.

\begin{tabular}{|c|c|c|c|c|}
\hline \multirow[b]{2}{*}{ Analyte } & \multirow[b]{2}{*}{ Ions } & \multicolumn{2}{|c|}{ GC/EI-MS Peak Areas } & \multirow[b]{2}{*}{ Sample/Blank ratio } \\
\hline & & Blank & Sample & \\
\hline Argon & 40,20 & $88,894,229$ & $74,301,213$ & 0.836 \\
\hline Oxygen & 32 & $7,523,412$ & $6,238,319$ & 0.829 \\
\hline $\mathrm{N} 2, \mathrm{CO}$ & 28 & $31,389,166$ & $39,497,807$ & 1.258 \\
\hline DCM & $34-38,46-52,82-90$ & $7,338,225$ & $5,835,370$ & 0.795 \\
\hline Benzene & $\mathrm{m} / \mathrm{z} 36-40,47-82$ & $262,728,952$ & $226,834,913$ & 0.863 \\
\hline \multicolumn{5}{|l|}{$\begin{array}{c}\text { Area normalized to } \\
\text { Benzene }\end{array}$} \\
\hline $\mathrm{N} 2, \mathrm{CO}$ & 28 & 0.119 & 0.174 & 1.457 \\
\hline \multicolumn{5}{|l|}{$\begin{array}{l}\text { Areas of lower } \mathrm{m} / \mathrm{z} \\
\text { ions }\end{array}$} \\
\hline $\mathrm{N}+,[\mathrm{CO}] 2+;[\mathrm{N} 2] 2+$ & $\mathrm{m} / \mathrm{z} 14$ & 513,394 & 697,470 & 1.359 \\
\hline $\mathrm{O}+,[\mathrm{O} 2] 2+$ & $\mathrm{m} / \mathrm{z} 16$ & 501,956 & 432,999 & 0.863 \\
\hline $\mathrm{C}+$ & $\mathrm{m} / \mathrm{z} 12$ & 2,209 & 19,307 & 8.741 \\
\hline
\end{tabular}

There was residual air in the sample and blank, most likely coming from the column and spectrometer surface. With the column used here, all the gases eluted at the same time and formed one GC/MS peak. The $\mathrm{m} / \mathrm{z} 28$ would be $\mathrm{N} 2$ and $\mathrm{CO}$. The $\mathrm{m} / \mathrm{z} 28$ peak area was higher for the sample than for the blank, implying $\mathrm{CO}$ in the sample. Upon electron ionization, $\mathrm{CO}$ would form an $\mathrm{m} / \mathrm{z} 12 \mathrm{C}+$ ion which would not form from oxygen, nitrogen or argon. While a much lower signal, its peak area in the sample was 8.7 times higher than in the blank. 


\section{Characterizations of poly(NBE): linear versus cyclic}

\subsection{Log of Molar Mass vs. elution volume}

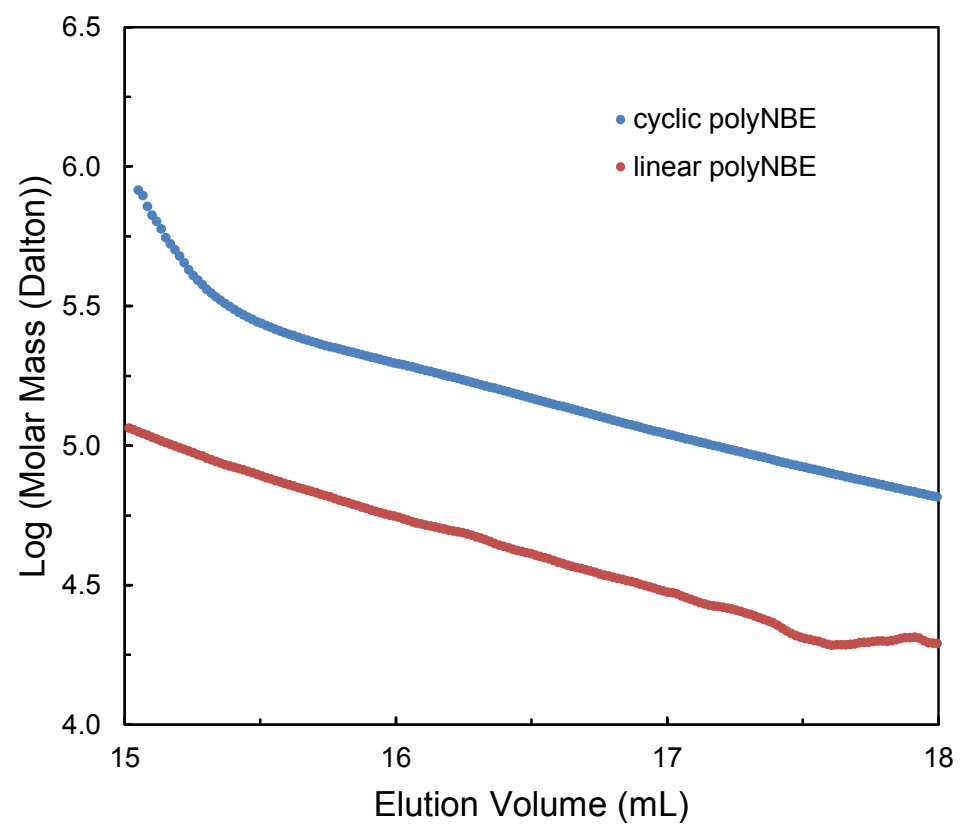

Figure S25. $\log$ of $M_{\mathrm{w}}$ versus elution volume for poly(NBE) synthesized by 2 (cyclic) and by 4 (linear).

\subsection{Mark-Houwink-Sakurada plot, $\log [\eta]$ versus $\log M w$}

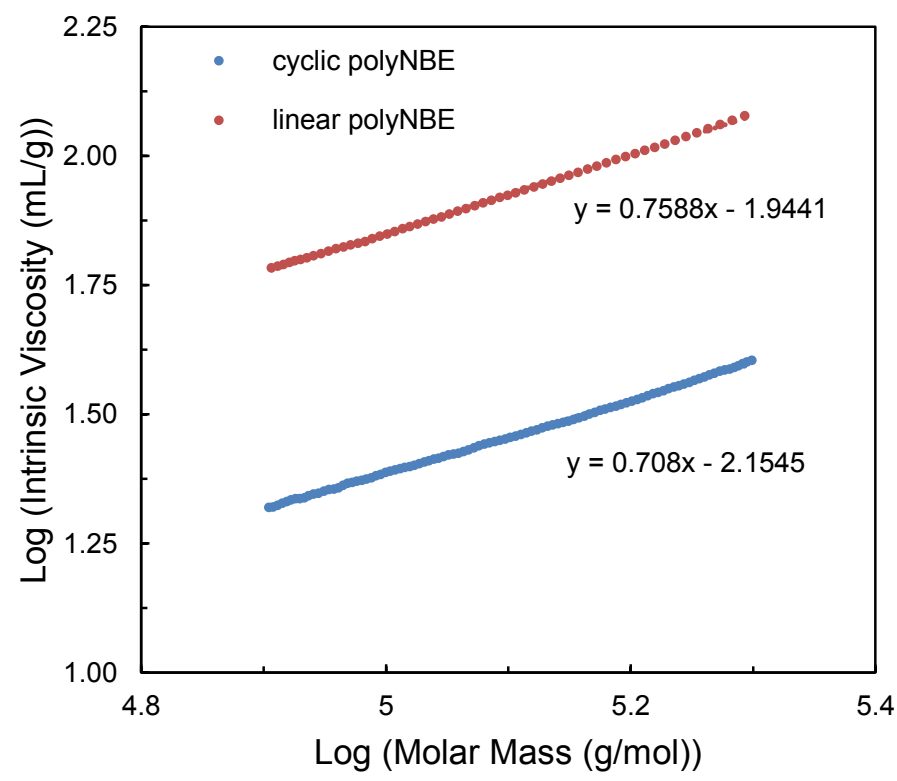

Figure S26. $\log$ of $[\eta]$ versus $\log M_{\mathrm{w}}$ for poly(NBE) synthesized by $\mathbf{2}$ (cyclic) and by $\mathbf{4}$ (linear). 
Table S2. Intrinsic viscosity data over a range of $M_{\mathrm{w}}$ for both cyclic and linear poly(NBE), and $[\eta]_{\text {cyclid }} /[\eta]_{\text {linear }}$.

\begin{tabular}{|c|c|c|c|c|}
\hline \multicolumn{2}{|c|}{ Cyclic } & \multicolumn{2}{c|}{ Linear } & \multirow{2}{*}[\eta]{$_{\text {cyclic }} /[\eta]_{\text {cyclic }}$} \\
\hline Molar Mass $(\mathrm{kDa})$ & {$[\eta]_{\text {cyclic }}(\mathrm{mL} / \mathrm{g})$} & Molar Mass $(\mathrm{kDa})$ & {$[\eta]_{\text {linear }}(\mathrm{mL} / \mathrm{g})$} & 0.345 \\
\hline 80.9 & 20.9 & 80.6 & 60.7 & 0.345 \\
\hline 91.5 & 22.8 & 91.0 & 66.1 & 0.348 \\
\hline 100.8 & 24.6 & 100.2 & 70.6 & 0.344 \\
\hline 111.4 & 26.2 & 111.0 & 76.2 & 0.341 \\
\hline 120.3 & 27.7 & 120.1 & 81.1 & 0.334 \\
\hline 130.2 & 29.1 & 132.0 & 87.0 & 0.335 \\
\hline 140.9 & 30.7 & 141.1 & 91.7 & 0.334 \\
\hline 151.1 & 32.4 & 151.3 & 97.0 & 0.333 \\
\hline 162.0 & 34.1 & 162.7 & 102.4 & \\
\hline
\end{tabular}

\subsection{Log of Molar Mass vs. elution volume}

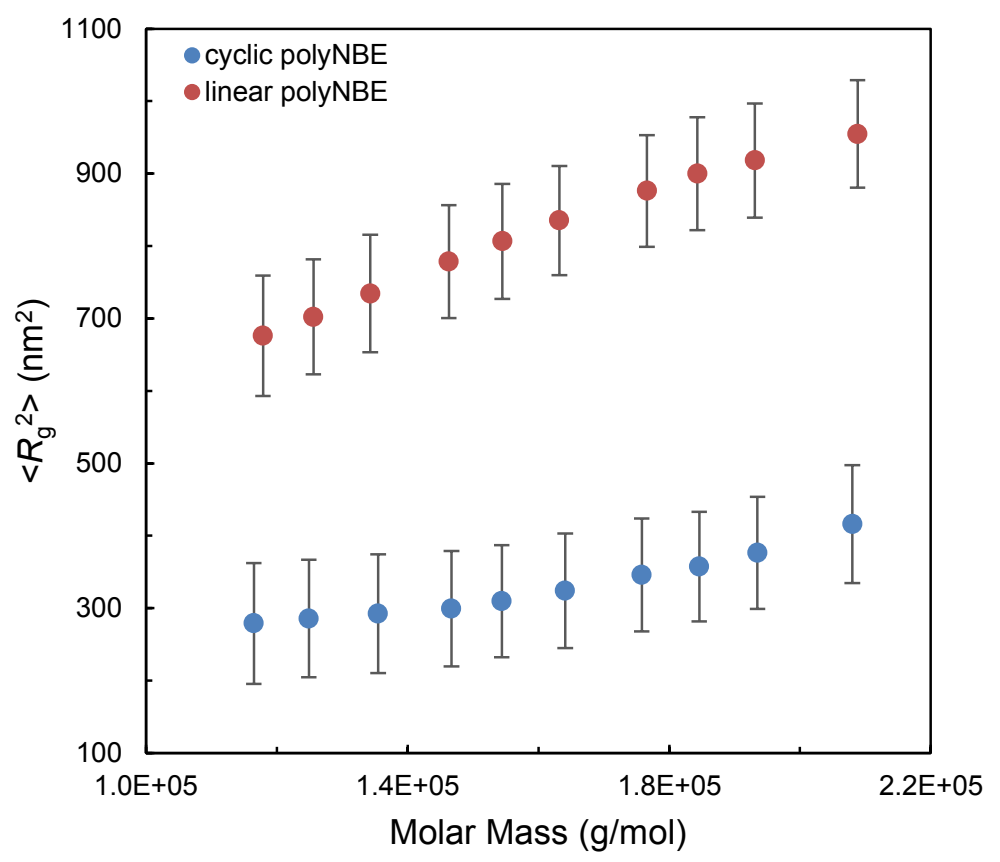

Figure S27. Plot of mean square radius $\left(<R_{\mathrm{g}}{ }^{2}>\right)$ versus $M_{\mathrm{w}}$ for poly(NBE) synthesized by $\mathbf{2}$ (cyclic) and by 4 (linear). 
Table S3. $R_{\mathrm{g}}{ }^{2}$ over a range of $M_{\mathrm{w}}$ for both cyclic and linear poly(NBE), and $\left\langle R_{\mathrm{g}}{ }^{2}\right\rangle_{\text {cyclic }} /\left\langle R_{\mathrm{g}}{ }^{2}\right\rangle_{\text {linear }}$

\begin{tabular}{|c|c|c|c|c|c|c|}
\hline \multicolumn{2}{|c|}{ Cyclic } & \multicolumn{2}{|c|}{ Linear } & \multirow{2}{*}{\multicolumn{3}{|c|}{$\left\langle R_{\mathrm{g}}^{2}\right\rangle_{\text {cyclic }} /\left\langle R_{\mathrm{g}}{ }^{2}\right\rangle_{\text {linear }}$}} \\
\hline Molar Mass (kDa) & $<R_{\mathrm{g}}^{2}>_{\text {cyclic }}\left(\mathrm{nm}^{2}\right)$ & Molar Mass $(\mathrm{kDa})$ & $\left\langle R_{\mathrm{g}}^{2}\right\rangle_{\text {linear }}\left(\mathrm{nm}^{2}\right)$ & & & \\
\hline 116.5 & $278.9 \pm 83.5$ & 117.9 & $676.0 \pm 83.2$ & 0.41 & \pm & 0.13 \\
\hline 124.9 & $285.6 \pm 81.1$ & 125.6 & $702.3 \pm 79.5$ & 0.41 & \pm & 0.12 \\
\hline 135.5 & $292.4 \pm 82.1$ & 134.3 & $734.4 \pm 81.3$ & 0.40 & \pm & 0.12 \\
\hline 146.7 & $299.3 \pm 79.6$ & 146.3 & 778.4 & 0.38 & \pm & 0.11 \\
\hline 154.4 & $309.8 \pm 77.4$ & 154.5 & 806.6 & 0.38 & \pm & 0.10 \\
\hline 164.1 & $324.0 \pm 79.2$ & 163.2 & 835.2 & 0.39 & \pm & 0.10 \\
\hline 175.8 & \pm 78.1 & 176.6 & $\pm \quad 77.0$ & 0.39 & \pm & 0.10 \\
\hline 184.6 & \pm 75.6 & 184.3 & \pm 78.0 & 0.40 & \pm & 0.09 \\
\hline 193.5 & $376.4 \pm 77.6$ & 193.1 & 918.1 & 0.41 & \pm & 0.09 \\
\hline 208 & \pm 81.6 & 208.8 & 954.8 & 0.44 & \pm & 0.09 \\
\hline
\end{tabular}

\section{X-Ray crystallography for complexes 2 and 3}

\subsection{Experimental procedure for structure 2}

X-Ray Intensity data were collected at $100 \mathrm{~K}$ on a Bruker DUO diffractometer using MoK $\alpha$ radiation $(\lambda=0.71073 \AA)$ and an APEXII CCD area detector.

Raw data frames were read by program $\mathrm{SAINT}^{7}$ and integrated using 3D profiling algorithms. The resulting data were reduced to produce hkl reflections and their intensities and estimated standard deviations. The data were corrected for Lorentz and polarization effects and numerical absorption corrections were applied based on indexed and measured faces.

The structure was solved and refined in SHELXTL2014, using full-matrix least-squares refinement. The non- $\mathrm{H}$ atoms were refined with anisotropic thermal parameters and all of the $\mathrm{H}$ atoms were calculated in idealized positions and refined riding on their parent atoms. In addition to the $\mathrm{W}$ complex, there are two half benzene solvent molecules in the asymmetric unit; each disordered around inversion symmetry elements. In the first disordered benzene molecule, two half molecules were refined with their site occupation factors refining to $0.55(1)$ and $0.45(1)$ for the major and minor parts, respectively. In the other solvent position, the C40-C45 molecule is positioned just off the inversion symmetry element and thus exists in $50 \%$ occupancy. The $\mathrm{C}_{4} \mathrm{H}_{8}$ part of the coordinated THF ligand is disordered and was refined in two parts with site 
occupation factors refined to $0.57(1)$ and $0.43(1)$, respectively. In the final cycle of refinement, 8614 reflections (of which 8331 are observed with $\mathrm{I}>2 \sigma(\mathrm{I})$ ) were used to refine 422 parameters and the resulting $\mathrm{R}_{1}, \mathrm{wR}_{2}$ and $\mathrm{S}$ (goodness of fit) were $2.00 \%, 5.18 \%$ and 1.090 , respectively. The refinement was carried out by minimizing the $\mathrm{wR}_{2}$ function using $\mathrm{F}^{2}$ rather than $\mathrm{F}$ values. $\mathrm{R}_{1}$ is calculated to provide a reference to the conventional $\mathrm{R}$ value but its function is not minimized.

\subsection{Crystal structure of 2}

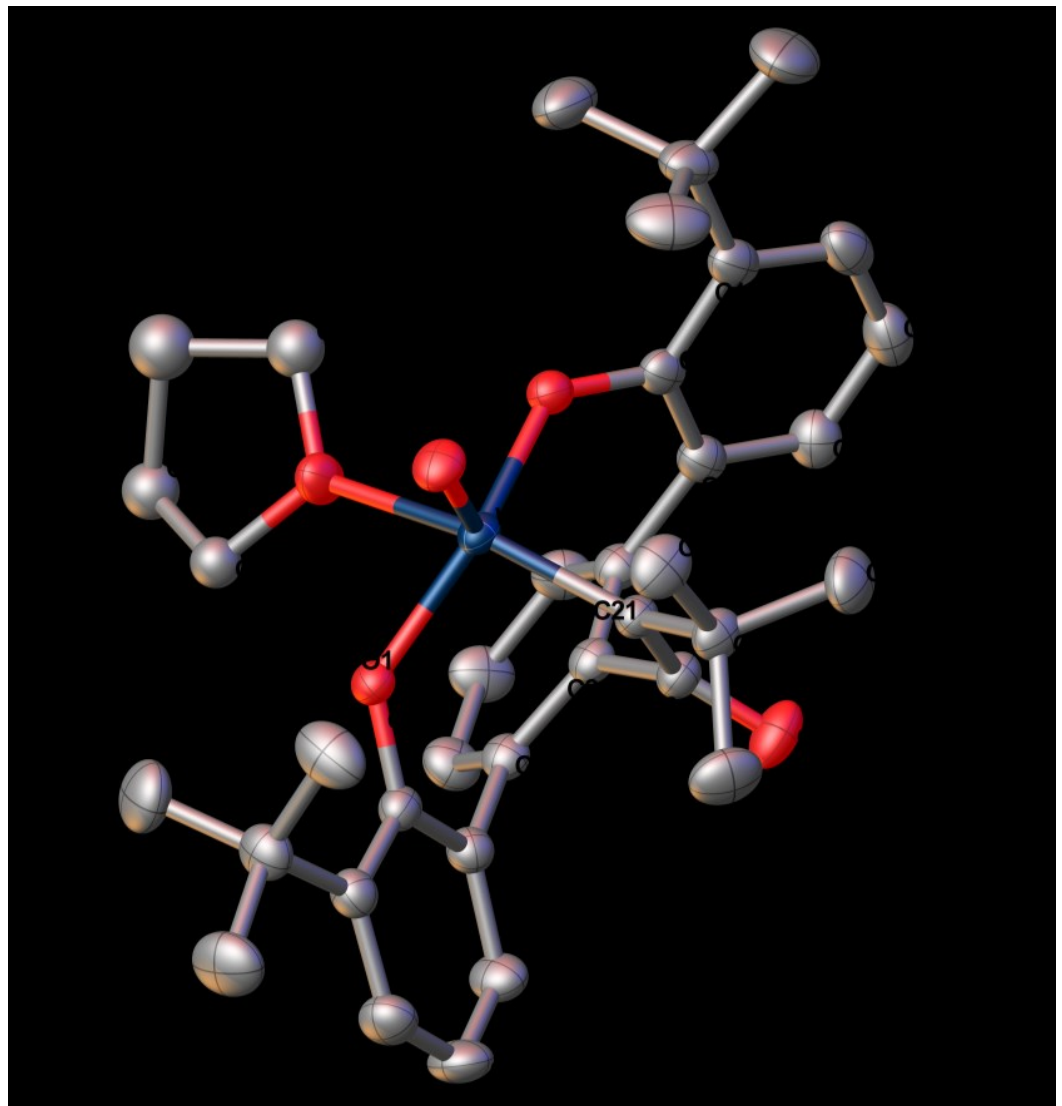

Figure S28. Molecular structure of 2. Ellipsoids shown at the 50\% probability level. Hydrogens, solvent molecule and disorder at the bound THF removed for clarity. 
Table S4. Crystal data and structure refinement for 2 .

Identification code

Empirical formula

Formula weight

Temperature

Wavelength

Crystal system

Space group

Unit cell dimensions

Volume

Z

Density (calculated)

Absorption coefficient

$\mathrm{F}(000)$

Crystal size

Theta range for data collection

Index ranges

Reflections collected

Independent reflections

Completeness to theta $=25.242^{\circ}$

Absorption correction

Max. and min. transmission

Refinement method

Data / restraints / parameters

Goodness-of-fit on $\mathrm{F}^{2}$

Final $\mathrm{R}$ indices $[\mathrm{I}>2 \operatorname{sigma}(\mathrm{I})]$

$\mathrm{R}$ indices (all data)

Extinction coefficient

Largest diff. peak and hole stella5

C42 H50 O5 W

818.67

100(2) K

$0.71073 \AA$

Triclinic

P 1

$$
\begin{array}{ll}
\mathrm{a}=10.6056(7) \AA & \alpha=82.8305(10)^{\circ} . \\
\mathrm{b}=11.5564(8) \AA & \beta=83.6334(10)^{\circ} . \\
\mathrm{c}=15.585(1) \AA & \gamma=83.687(1)^{\circ} .
\end{array}
$$

$1874.5(2) \AA^{3}$

2

$1.450 \mathrm{Mg} / \mathrm{m}^{3}$

$3.124 \mathrm{~mm}^{-1}$

832

$0.399 \times 0.205 \times 0.112 \mathrm{~mm}^{3}$

1.323 to $27.500^{\circ}$.

$-13 \leq \mathrm{h} \leq 13,-15 \leq \mathrm{k} \leq 15,-20 \leq \mathrm{l} \leq 20$

44174

$8614[\mathrm{R}(\mathrm{int})=0.0422]$

$100.0 \%$

Analytical

0.8417 and 0.5038

Full-matrix least-squares on $\mathrm{F}^{2}$

8614 / 0 / 422

1.090

$\mathrm{R} 1=0.0200, \mathrm{wR} 2=0.0518[8331]$

$\mathrm{R} 1=0.0208, \mathrm{wR} 2=0.0523$

$\mathrm{n} / \mathrm{a}$

1.174 and -1.123 e. $\AA^{-3}$

$\mathrm{R} 1=\sum\left(|| \mathrm{F}_{\mathrm{O}}|-| \mathrm{F}_{\mathcal{G}} \mid\right) / \sum_{2}\left|\mathrm{~F}_{\mathrm{O}}\right|$
$\left.\left.\mathrm{wR} 2=\left[\sum\left[\mathrm{w}_{2} \mathrm{~F}_{\mathrm{O}}-\mathrm{F}_{\mathcal{G}^{2}}\right)^{2}\right] / \sum\left[\mathrm{w}_{(} \mathrm{F}_{\mathrm{O}}{ }^{2}\right)^{2}\right]\right]^{1 / 2}$

$\mathrm{S}=\left[\sum\left[\mathrm{w}_{2}\left(\mathrm{~F}_{\mathrm{O}}{ }_{2}-\mathrm{F}_{\mathrm{c}}{ }^{2}\right)^{2}\right] /(\mathrm{n}-\mathrm{p})\right]$

$\mathrm{w}=1 /\left[\sigma^{2}\left(\mathrm{~F}_{\mathrm{O}}{ }^{2}\right)+(\mathrm{m} * \mathrm{p})^{2}+\mathrm{n} * \mathrm{p}\right], \mathrm{p}=\left[\max \left(\mathrm{F}_{\mathrm{O}}{ }^{2}, 0\right)+2 * \mathrm{~F}_{\mathrm{c}}{ }^{2}\right] / 3, \mathrm{~m} \& \mathrm{n}$ are constants. 
Table S5. Atomic coordinates $\left(\mathrm{x} 10^{4}\right)$ and equivalent isotropic displacement parameters $\left(\AA^{2} \mathrm{x}\right.$ $10^{3}$ ) for 2 . $U(e q)$ is defined as one third of the trace of the orthogonalized $U^{i j}$ tensor.

\begin{tabular}{|c|c|c|c|c|}
\hline & $\mathrm{x}$ & $\mathrm{y}$ & z & $\mathrm{U}(\mathrm{eq})$ \\
\hline $\mathrm{W}(1)$ & $6089(1)$ & 7899(1) & $2215(1)$ & $23(1)$ \\
\hline $\mathrm{O}(1)$ & $7312(1)$ & $6532(1)$ & $2407(1)$ & $26(1)$ \\
\hline $\mathrm{O}(2)$ & $5272(1)$ & 9361(1) & $2612(1)$ & $28(1)$ \\
\hline $\mathrm{O}(3)$ & $3367(2)$ & $6249(2)$ & $3592(1)$ & $43(1)$ \\
\hline $\mathrm{O}(4)$ & $6344(2)$ & $8258(2)$ & $1126(1)$ & $33(1)$ \\
\hline $\mathrm{O}(5)$ & 7701(2) & $8632(2)$ & $2750(1)$ & $35(1)$ \\
\hline$C(1)$ & $7175(2)$ & $5409(2)$ & $2764(1)$ & $25(1)$ \\
\hline$C(2)$ & $6573(2)$ & $5224(2)$ & $3616(1)$ & $27(1)$ \\
\hline$C(3)$ & $6426(2)$ & $4090(2)$ & $4002(2)$ & $36(1)$ \\
\hline$C(4)$ & 6852(3) & $3154(2)$ & $3541(2)$ & $42(1)$ \\
\hline$C(5)$ & $7478(2)$ & $3342(2)$ & $2713(2)$ & $38(1)$ \\
\hline$C(6)$ & $7683(2)$ & $4463(2)$ & $2305(1)$ & $29(1)$ \\
\hline$C(7)$ & $8466(2)$ & $4635(2)$ & $1416(2)$ & $36(1)$ \\
\hline$C(8)$ & 7671(3) & $5364(3)$ & $739(2)$ & $50(1)$ \\
\hline $\mathrm{C}(9)$ & $9650(3)$ & $5245(3)$ & $1517(2)$ & $52(1)$ \\
\hline$C(10)$ & $8919(3)$ & $3461(3)$ & $1069(2)$ & $54(1)$ \\
\hline $\mathrm{C}(11)$ & $4158(2)$ & $9662(2)$ & $3080(1)$ & $27(1)$ \\
\hline$C(12)$ & $3900(2)$ & $9043(2)$ & $3907(1)$ & $28(1)$ \\
\hline$C(13)$ & $2772(2)$ & $9346(2)$ & $4415(2)$ & $36(1)$ \\
\hline$C(14)$ & 1916(2) & $10250(2)$ & $4103(2)$ & $41(1)$ \\
\hline$C(15)$ & 2191(2) & $10865(2)$ & $3296(2)$ & $38(1)$ \\
\hline$C(16)$ & $3309(2)$ & $10608(2)$ & $2759(2)$ & $32(1)$ \\
\hline$C(17)$ & $3606(2)$ & $11339(2)$ & $1880(2)$ & $39(1)$ \\
\hline$C(18)$ & 3801(4) & 10561(3) & $1140(2)$ & $56(1)$ \\
\hline$C(19)$ & $4810(3)$ & 11964(3) & $1903(2)$ & $54(1)$ \\
\hline$C(20)$ & 2521(3) & $12290(3)$ & 1677(3) & $62(1)$ \\
\hline $\mathrm{C}(21)$ & $4570(2)$ & 7064(2) & $2300(1)$ & $24(1)$ \\
\hline$C(22)$ & $4269(2)$ & $6752(2)$ & $3236(1)$ & $26(1)$ \\
\hline $\mathrm{C}(23)$ & $5187(2)$ & 7091(2) & $3833(1)$ & $25(1)$ \\
\hline$C(24)$ & $6169(2)$ & $6258(2)$ & $4098(1)$ & $27(1)$ \\
\hline$C(25)$ & 6781(2) & $6416(2)$ & $4816(2)$ & $35(1)$ \\
\hline
\end{tabular}




\begin{tabular}{|c|c|c|c|c|}
\hline$C(26)$ & $6433(3)$ & 7401(2) & $5244(2)$ & $39(1)$ \\
\hline$C(27)$ & $5506(2)$ & $8258(2)$ & 4952(1) & $34(1)$ \\
\hline$C(28)$ & $4869(2)$ & $8114(2)$ & $4244(1)$ & $28(1)$ \\
\hline$C(29)$ & $3720(2)$ & $6687(2)$ & $1673(1)$ & $31(1)$ \\
\hline$C(30)$ & $3768(3)$ & $5340(2)$ & 1792(2) & $48(1)$ \\
\hline$C(31)$ & $4152(3)$ & 7088(3) & $722(2)$ & $42(1)$ \\
\hline$C(32)$ & $2342(2)$ & 7231(3) & $1882(2)$ & $46(1)$ \\
\hline$C(33)$ & $8855(4)$ & 7944(4) & $3070(4)$ & $32(1)$ \\
\hline$C(34)$ & $9485(5)$ & $8780(5)$ & $3487(4)$ & $40(1)$ \\
\hline$C(35)$ & $9189(6)$ & 9979(5) & $2819(5)$ & $53(2)$ \\
\hline$C(36)$ & $7823(5)$ & 9883(4) & $2678(4)$ & $41(1)$ \\
\hline$C\left(33^{\prime}\right)$ & $8998(7)$ & $8078(7)$ & $2795(6)$ & $41(2)$ \\
\hline$C\left(34^{\prime}\right)$ & $9697(10)$ & 8943(9) & $3153(8)$ & $67(2)$ \\
\hline$C\left(35^{\prime}\right)$ & $8948(6)$ & $9967(6)$ & $3221(5)$ & $40(2)$ \\
\hline$C\left(36^{\prime}\right)$ & $7613(5)$ & 9814(5) & $3046(5)$ & $32(1)$ \\
\hline$C(37)$ & $9468(11)$ & $8966(7)$ & 299(4) & $54(2)$ \\
\hline$C(38)$ & $8693(6)$ & $9984(10)$ & $235(4)$ & $47(2)$ \\
\hline C(39) & $9222(9)$ & $11024(7)$ & $-73(4)$ & $51(2)$ \\
\hline$C\left(37^{\prime}\right)$ & $10069(14)$ & $8812(7)$ & $257(5)$ & $54(2)$ \\
\hline $\mathrm{C}\left(38^{\prime}\right)$ & $8919(10)$ & $9489(13)$ & $273(5)$ & $53(2)$ \\
\hline$C\left(39^{\prime}\right)$ & $8833(10)$ & $10676(11)$ & $29(6)$ & $55(2)$ \\
\hline$C(40)$ & $464(4)$ & $5462(4)$ & $4229(2)$ & $41(1)$ \\
\hline$C(41)$ & $660(4)$ & $6132(3)$ & $4875(3)$ & $52(1)$ \\
\hline$C(42)$ & 194(4) & $5815(4)$ & $5732(2)$ & $53(1)$ \\
\hline$C(43)$ & $-468(4)$ & $4829(4)$ & $5942(2)$ & $46(1)$ \\
\hline$C(44)$ & $-664(4)$ & $4159(3)$ & $5296(3)$ & $44(1)$ \\
\hline$C(45)$ & $-198(4)$ & $4476(3)$ & $4440(2)$ & $48(1)$ \\
\hline
\end{tabular}


Table S6. Bond lengths $[\AA]$ and angles $\left[{ }^{\circ}\right]$ for 2.

\begin{tabular}{|c|c|}
\hline $\mathrm{W}(1)-\mathrm{O}(4)$ & $1.6948(15)$ \\
\hline $\mathrm{W}(1)-\mathrm{O}(1)$ & $1.9454(15)$ \\
\hline $\mathrm{W}(1)-\mathrm{C}(21)$ & $1.9503(19)$ \\
\hline $\mathrm{W}(1)-\mathrm{O}(2)$ & $1.9510(15)$ \\
\hline $\mathrm{W}(1)-\mathrm{O}(5)$ & $2.2689(15)$ \\
\hline $\mathrm{O}(1)-\mathrm{C}(1)$ & $1.363(3)$ \\
\hline $\mathrm{O}(2)-\mathrm{C}(11)$ & $1.354(3)$ \\
\hline $\mathrm{O}(3)-\mathrm{C}(22)$ & $1.219(3)$ \\
\hline $\mathrm{O}(5)-\mathrm{C}(36)$ & $1.455(5)$ \\
\hline $\mathrm{O}(5)-\mathrm{C}\left(33^{\prime}\right)$ & $1.457(7)$ \\
\hline $\mathrm{O}(5)-\mathrm{C}(33)$ & $1.484(5)$ \\
\hline $\mathrm{O}(5)-\mathrm{C}\left(36^{\prime}\right)$ & $1.486(6)$ \\
\hline $\mathrm{C}(1)-\mathrm{C}(6)$ & $1.406(3)$ \\
\hline $\mathrm{C}(1)-\mathrm{C}(2)$ & $1.410(3)$ \\
\hline $\mathrm{C}(2)-\mathrm{C}(3)$ & $1.391(3)$ \\
\hline$C(2)-C(24)$ & $1.489(3)$ \\
\hline $\mathrm{C}(3)-\mathrm{C}(4)$ & $1.380(4)$ \\
\hline $\mathrm{C}(3)-\mathrm{H}(3 \mathrm{~A})$ & 0.9500 \\
\hline$C(4)-C(5)$ & $1.388(4)$ \\
\hline $\mathrm{C}(4)-\mathrm{H}(4 \mathrm{~A})$ & 0.9500 \\
\hline$C(5)-C(6)$ & $1.398(3)$ \\
\hline $\mathrm{C}(5)-\mathrm{H}(5 \mathrm{~A})$ & 0.9500 \\
\hline$C(6)-C(7)$ & $1.537(3)$ \\
\hline$C(7)-C(10)$ & $1.532(4)$ \\
\hline$C(7)-C(8)$ & $1.533(4)$ \\
\hline $\mathrm{C}(7)-\mathrm{C}(9)$ & $1.538(4)$ \\
\hline $\mathrm{C}(11)-\mathrm{C}(12)$ & $1.408(3)$ \\
\hline$C(11)-C(16)$ & $1.415(3)$ \\
\hline$C(12)-C(13)$ & $1.396(3)$ \\
\hline $\mathrm{C}(12)-\mathrm{C}(28)$ & $1.491(3)$ \\
\hline$C(13)-C(14)$ & $1.384(4)$ \\
\hline$C(14)-C(15)$ & $1.383(4)$ \\
\hline$C(15)-C(16)$ & $1.400(3)$ \\
\hline$C(16)-C(17)$ & $1.538(3)$ \\
\hline
\end{tabular}




\begin{tabular}{|c|c|}
\hline$C(17)-C(18)$ & $1.531(4)$ \\
\hline$C(17)-C(20)$ & $1.532(4)$ \\
\hline$C(17)-C(19)$ & $1.541(4)$ \\
\hline$C(21)-C(22)$ & $1.466(3)$ \\
\hline$C(21)-C(29)$ & $1.532(3)$ \\
\hline$C(22)-C(23)$ & $1.531(3)$ \\
\hline$C(23)-C(24)$ & $1.399(3)$ \\
\hline$C(23)-C(28)$ & $1.406(3)$ \\
\hline$C(24)-C(25)$ & $1.395(3)$ \\
\hline$C(25)-C(26)$ & $1.386(3)$ \\
\hline$C(26)-C(27)$ & $1.388(3)$ \\
\hline$C(27)-C(28)$ & $1.392(3)$ \\
\hline$C(29)-C(31)$ & $1.531(3)$ \\
\hline$C(29)-C(30)$ & $1.539(4)$ \\
\hline$C(29)-C(32)$ & $1.543(3)$ \\
\hline$C(33)-C(34)$ & $1.482(7)$ \\
\hline$C(34)-C(35)$ & $1.649(9)$ \\
\hline$C(35)-C(36)$ & $1.507(7)$ \\
\hline$C\left(33^{\prime}\right)-C\left(34^{\prime}\right)$ & $1.501(12)$ \\
\hline$C\left(34^{\prime}\right)-C\left(35^{\prime}\right)$ & $1.360(12)$ \\
\hline$C\left(35^{\prime}\right)-C\left(36^{\prime}\right)$ & $1.504(8)$ \\
\hline $\mathrm{C}(37)-\mathrm{C}(38)$ & $1.360(9)$ \\
\hline C(37)-C(39)\#1 & $1.396(9)$ \\
\hline C(38)-C(39) & $1.390(9)$ \\
\hline$C(39)-C(37) \# 1$ & $1.396(9)$ \\
\hline $\mathrm{C}\left(37^{\prime}\right)-\mathrm{C}\left(39^{\prime}\right) \# 1$ & $1.369(12)$ \\
\hline C(37')-C(38') & $1.373(12)$ \\
\hline $\mathrm{C}\left(38^{\prime}\right)-\mathrm{C}\left(39^{\prime}\right)$ & $1.373(13)$ \\
\hline $\mathrm{C}\left(39^{\prime}\right)-\mathrm{C}\left(37^{\prime}\right) \# 1$ & $1.369(12)$ \\
\hline $\mathrm{O}(4)-\mathrm{W}(1)-\mathrm{O}(1)$ & $102.02(7)$ \\
\hline $\mathrm{O}(4)-\mathrm{W}(1)-\mathrm{C}(21)$ & $101.28(8)$ \\
\hline $\mathrm{O}(1)-\mathrm{W}(1)-\mathrm{C}(21)$ & $97.27(7)$ \\
\hline $\mathrm{O}(4)-\mathrm{W}(1)-\mathrm{O}(2)$ & $102.48(7)$ \\
\hline $\mathrm{O}(1)-\mathrm{W}(1)-\mathrm{O}(2)$ & $147.84(6)$ \\
\hline $\mathrm{C}(21)-\mathrm{W}(1)-\mathrm{O}(2)$ & $98.02(7)$ \\
\hline
\end{tabular}




\begin{tabular}{|c|c|}
\hline $\mathrm{O}(4)-\mathrm{W}(1)-\mathrm{O}(5)$ & $103.96(7)$ \\
\hline $\mathrm{O}(1)-\mathrm{W}(1)-\mathrm{O}(5)$ & $76.94(6)$ \\
\hline $\mathrm{C}(21)-\mathrm{W}(1)-\mathrm{O}(5)$ & $154.75(8)$ \\
\hline $\mathrm{O}(2)-\mathrm{W}(1)-\mathrm{O}(5)$ & $77.18(6)$ \\
\hline $\mathrm{C}(1)-\mathrm{O}(1)-\mathrm{W}(1)$ & $132.33(12)$ \\
\hline $\mathrm{C}(11)-\mathrm{O}(2)-\mathrm{W}(1)$ & $134.17(13)$ \\
\hline $\mathrm{C}(36)-\mathrm{O}(5)-\mathrm{C}(33)$ & $110.9(3)$ \\
\hline $\mathrm{C}\left(33^{\prime}\right)-\mathrm{O}(5)-\mathrm{C}\left(36^{\prime}\right)$ & $109.2(4)$ \\
\hline $\mathrm{C}(36)-\mathrm{O}(5)-\mathrm{W}(1)$ & $122.3(2)$ \\
\hline $\mathrm{C}\left(33^{\prime}\right)-\mathrm{O}(5)-\mathrm{W}(1)$ & $126.3(3)$ \\
\hline $\mathrm{C}(33)-\mathrm{O}(5)-\mathrm{W}(1)$ & $126.0(2)$ \\
\hline $\mathrm{C}\left(36^{\prime}\right)-\mathrm{O}(5)-\mathrm{W}(1)$ & $124.3(2)$ \\
\hline $\mathrm{O}(1)-\mathrm{C}(1)-\mathrm{C}(6)$ & $120.37(18)$ \\
\hline $\mathrm{O}(1)-\mathrm{C}(1)-\mathrm{C}(2)$ & $118.32(19)$ \\
\hline$C(6)-C(1)-C(2)$ & $121.2(2)$ \\
\hline $\mathrm{C}(3)-\mathrm{C}(2)-\mathrm{C}(1)$ & $119.9(2)$ \\
\hline$C(3)-C(2)-C(24)$ & $121.47(19)$ \\
\hline$C(1)-C(2)-C(24)$ & $118.58(19)$ \\
\hline $\mathrm{C}(4)-\mathrm{C}(3)-\mathrm{C}(2)$ & $119.6(2)$ \\
\hline$C(3)-C(4)-C(5)$ & $120.1(2)$ \\
\hline$C(4)-C(5)-C(6)$ & $122.5(2)$ \\
\hline$C(5)-C(6)-C(1)$ & $116.5(2)$ \\
\hline$C(5)-C(6)-C(7)$ & $121.1(2)$ \\
\hline$C(1)-C(6)-C(7)$ & $122.3(2)$ \\
\hline $\mathrm{C}(10)-\mathrm{C}(7)-\mathrm{C}(8)$ & $107.1(2)$ \\
\hline$C(10)-C(7)-C(6)$ & $111.5(2)$ \\
\hline$C(8)-C(7)-C(6)$ & $111.14(19)$ \\
\hline$C(10)-C(7)-C(9)$ & $108.0(2)$ \\
\hline $\mathrm{C}(8)-\mathrm{C}(7)-\mathrm{C}(9)$ & $110.3(2)$ \\
\hline$C(6)-C(7)-C(9)$ & $108.7(2)$ \\
\hline $\mathrm{O}(2)-\mathrm{C}(11)-\mathrm{C}(12)$ & $118.10(19)$ \\
\hline $\mathrm{O}(2)-\mathrm{C}(11)-\mathrm{C}(16)$ & $120.59(19)$ \\
\hline$C(12)-C(11)-C(16)$ & $121.3(2)$ \\
\hline$C(13)-C(12)-C(11)$ & $119.7(2)$ \\
\hline$C(13)-C(12)-C(28)$ & $120.9(2)$ \\
\hline $\mathrm{C}(11)-\mathrm{C}(12)-\mathrm{C}(28)$ & $119.28(19)$ \\
\hline
\end{tabular}




\begin{tabular}{|c|c|}
\hline$C(14)-C(13)-C(12)$ & $119.8(2)$ \\
\hline$C(15)-C(14)-C(13)$ & $120.0(2)$ \\
\hline$C(14)-C(15)-C(16)$ & $122.8(2)$ \\
\hline$C(15)-C(16)-C(11)$ & $116.4(2)$ \\
\hline$C(15)-C(16)-C(17)$ & $121.4(2)$ \\
\hline$C(11)-C(16)-C(17)$ & $122.2(2)$ \\
\hline $\mathrm{C}(18)-\mathrm{C}(17)-\mathrm{C}(20)$ & $107.5(2)$ \\
\hline $\mathrm{C}(18)-\mathrm{C}(17)-\mathrm{C}(16)$ & $110.8(2)$ \\
\hline$C(20)-C(17)-C(16)$ & $111.7(2)$ \\
\hline$C(18)-C(17)-C(19)$ & $110.0(3)$ \\
\hline$C(20)-C(17)-C(19)$ & $107.2(2)$ \\
\hline$C(16)-C(17)-C(19)$ & $109.5(2)$ \\
\hline$C(22)-C(21)-C(29)$ & $118.59(17)$ \\
\hline$C(22)-C(21)-W(1)$ & $104.31(13)$ \\
\hline$C(29)-C(21)-W(1)$ & $137.09(15)$ \\
\hline $\mathrm{O}(3)-\mathrm{C}(22)-\mathrm{C}(21)$ & $127.14(19)$ \\
\hline $\mathrm{O}(3)-\mathrm{C}(22)-\mathrm{C}(23)$ & $116.22(18)$ \\
\hline$C(21)-C(22)-C(23)$ & $116.64(16)$ \\
\hline$C(24)-C(23)-C(28)$ & $120.95(19)$ \\
\hline$C(24)-C(23)-C(22)$ & $118.55(19)$ \\
\hline$C(28)-C(23)-C(22)$ & $119.07(19)$ \\
\hline $\mathrm{C}(25)-\mathrm{C}(24)-\mathrm{C}(23)$ & 119.1(2) \\
\hline$C(25)-C(24)-C(2)$ & $120.1(2)$ \\
\hline$C(23)-C(24)-C(2)$ & $120.74(18)$ \\
\hline$C(26)-C(25)-C(24)$ & $119.9(2)$ \\
\hline$C(25)-C(26)-C(27)$ & $120.9(2)$ \\
\hline$C(26)-C(27)-C(28)$ & $120.3(2)$ \\
\hline$C(27)-C(28)-C(23)$ & $118.7(2)$ \\
\hline $\mathrm{C}(27)-\mathrm{C}(28)-\mathrm{C}(12)$ & $120.8(2)$ \\
\hline$C(23)-C(28)-C(12)$ & $120.45(18)$ \\
\hline$C(31)-C(29)-C(21)$ & $112.19(18)$ \\
\hline$C(31)-C(29)-C(30)$ & $108.5(2)$ \\
\hline$C(21)-C(29)-C(30)$ & $108.77(19)$ \\
\hline $\mathrm{C}(31)-\mathrm{C}(29)-\mathrm{C}(32)$ & $108.3(2)$ \\
\hline$C(21)-C(29)-C(32)$ & 108.91(19) \\
\hline$C(30)-C(29)-C(32)$ & $110.1(2)$ \\
\hline
\end{tabular}




$\begin{array}{lr}\mathrm{C}(34)-\mathrm{C}(33)-\mathrm{O}(5) & 104.9(3) \\ \mathrm{C}(33)-\mathrm{C}(34)-\mathrm{C}(35) & 99.6(4) \\ \mathrm{C}(36)-\mathrm{C}(35)-\mathrm{C}(34) & 100.8(4) \\ \mathrm{O}(5)-\mathrm{C}(36)-\mathrm{C}(35) & 105.3(4) \\ \mathrm{O}(5)-\mathrm{C}\left(33^{\prime}\right)-\mathrm{C}\left(34^{\prime}\right) & 105.2(6) \\ \mathrm{C}\left(35^{\prime}\right)-\mathrm{C}\left(34^{\prime}\right)-\mathrm{C}\left(33^{\prime}\right) & 110.6(7) \\ \mathrm{C}\left(34^{\prime}\right)-\mathrm{C}\left(35^{\prime}\right)-\mathrm{C}\left(36^{\prime}\right) & 109.5(6) \\ \mathrm{O}(5)-\mathrm{C}\left(36^{\prime}\right)-\mathrm{C}\left(35^{\prime}\right) & 104.8(4) \\ \mathrm{C}(38)-\mathrm{C}(37)-\mathrm{C}(39) \# 1 & 120.0(6) \\ \mathrm{C}(37)-\mathrm{C}(38)-\mathrm{C}(39) & 119.0(6) \\ \mathrm{C}(38)-\mathrm{C}(39)-\mathrm{C}(37) \# 1 & 121.0(6) \\ \mathrm{C}\left(39^{\prime}\right) \# 1-\mathrm{C}\left(37^{\prime}\right)-\mathrm{C}\left(38^{\prime}\right) & 119.5(8) \\ \mathrm{C}\left(39^{\prime}\right)-\mathrm{C}\left(38^{\prime}\right)-\mathrm{C}\left(37^{\prime}\right) & 122.0(8) \\ \mathrm{C}\left(37^{\prime}\right) \# 1-\mathrm{C}\left(39^{\prime}\right)-\mathrm{C}\left(38^{\prime}\right) & 118.4(8)\end{array}$

Symmetry transformations used to generate equivalent atoms:

$\# 1-x+2,-y+2,-z$ 
Table S7. Anisotropic displacement parameters $\left(\AA^{2} \times 10^{3}\right)$ for 2 . The anisotropic displacement factor exponent takes the form: $-2 \pi^{2}\left[\mathrm{~h}^{2} \mathrm{a}^{* 2} \mathrm{U}^{11}+\ldots+2 \mathrm{hk} \mathrm{a}^{*} \mathrm{~b}^{*} \mathrm{U}^{12}\right]$

\begin{tabular}{|c|c|c|c|c|c|c|}
\hline & $\mathrm{U}^{11}$ & $\mathrm{U}^{22}$ & $\mathrm{U}^{33}$ & $\mathrm{U}^{23}$ & $\mathrm{U}^{13}$ & $\mathrm{U}^{12}$ \\
\hline $\mathrm{W}(1)$ & $23(1)$ & $25(1)$ & $21(1)$ & $2(1)$ & $-3(1)$ & $-6(1)$ \\
\hline $\mathrm{O}(1)$ & $24(1)$ & $26(1)$ & $26(1)$ & $1(1)$ & $-1(1)$ & $-4(1)$ \\
\hline $\mathrm{O}(2)$ & $27(1)$ & $25(1)$ & $31(1)$ & $0(1)$ & $-5(1)$ & $-4(1)$ \\
\hline $\mathrm{O}(3)$ & $39(1)$ & $60(1)$ & $32(1)$ & $2(1)$ & $0(1)$ & $-24(1)$ \\
\hline $\mathrm{O}(4)$ & $35(1)$ & $38(1)$ & $24(1)$ & $6(1)$ & $-3(1)$ & $-8(1)$ \\
\hline $\mathrm{O}(5)$ & $28(1)$ & $32(1)$ & $49(1)$ & $-6(1)$ & $-14(1)$ & $-5(1)$ \\
\hline$C(1)$ & $23(1)$ & $27(1)$ & $25(1)$ & $1(1)$ & $-4(1)$ & $-4(1)$ \\
\hline$C(2)$ & $28(1)$ & $28(1)$ & $24(1)$ & $-1(1)$ & $-3(1)$ & $-2(1)$ \\
\hline$C(3)$ & $43(1)$ & $33(1)$ & $29(1)$ & $5(1)$ & $2(1)$ & $-3(1)$ \\
\hline $\mathrm{C}(4)$ & $54(2)$ & $25(1)$ & $42(1)$ & $5(1)$ & $1(1)$ & $-4(1)$ \\
\hline$C(5)$ & $43(1)$ & $30(1)$ & $40(1)$ & $-7(1)$ & $-1(1)$ & $0(1)$ \\
\hline$C(6)$ & $28(1)$ & $31(1)$ & $28(1)$ & $-3(1)$ & $-3(1)$ & $0(1)$ \\
\hline$C(7)$ & $36(1)$ & $39(1)$ & $30(1)$ & $-6(1)$ & $3(1)$ & $2(1)$ \\
\hline$C(8)$ & $58(2)$ & $59(2)$ & $27(1)$ & $-5(1)$ & $1(1)$ & $12(1)$ \\
\hline $\mathrm{C}(9)$ & $37(1)$ & $66(2)$ & $51(2)$ & $-9(1)$ & $13(1)$ & $-10(1)$ \\
\hline$C(10)$ & $63(2)$ & $49(2)$ & $45(2)$ & $-14(1)$ & $13(1)$ & $7(1)$ \\
\hline $\mathrm{C}(11)$ & $27(1)$ & $24(1)$ & $32(1)$ & $-4(1)$ & $-8(1)$ & $-6(1)$ \\
\hline$C(12)$ & $30(1)$ & $26(1)$ & $31(1)$ & $-5(1)$ & $-7(1)$ & $-4(1)$ \\
\hline$C(13)$ & $35(1)$ & $41(1)$ & $34(1)$ & $-9(1)$ & $-2(1)$ & $-4(1)$ \\
\hline$C(14)$ & $30(1)$ & $46(1)$ & $48(1)$ & $-15(1)$ & $-5(1)$ & $0(1)$ \\
\hline$C(15)$ & $32(1)$ & $33(1)$ & $53(1)$ & $-10(1)$ & $-16(1)$ & $2(1)$ \\
\hline$C(16)$ & $31(1)$ & $27(1)$ & $40(1)$ & $-4(1)$ & $-13(1)$ & $-5(1)$ \\
\hline$C(17)$ & $42(1)$ & $28(1)$ & $49(1)$ & $7(1)$ & $-19(1)$ & $-3(1)$ \\
\hline $\mathrm{C}(18)$ & $86(2)$ & $44(2)$ & $39(1)$ & $6(1)$ & $-24(1)$ & $-2(2)$ \\
\hline$C(19)$ & $52(2)$ & $40(2)$ & $69(2)$ & $16(1)$ & $-17(1)$ & $-15(1)$ \\
\hline$C(20)$ & $55(2)$ & $46(2)$ & $80(2)$ & $19(2)$ & $-24(2)$ & $6(1)$ \\
\hline$C(21)$ & $23(1)$ & $24(1)$ & $24(1)$ & $0(1)$ & $-4(1)$ & $-4(1)$ \\
\hline$C(22)$ & $25(1)$ & $28(1)$ & $25(1)$ & $-1(1)$ & $-3(1)$ & $-6(1)$ \\
\hline$C(23)$ & $27(1)$ & $28(1)$ & $19(1)$ & $1(1)$ & $-2(1)$ & $-6(1)$ \\
\hline$C(24)$ & $29(1)$ & $29(1)$ & $21(1)$ & $1(1)$ & $-2(1)$ & $-5(1)$ \\
\hline$C(25)$ & $39(1)$ & $38(1)$ & $29(1)$ & $-1(1)$ & $-12(1)$ & $1(1)$ \\
\hline
\end{tabular}




\begin{tabular}{lllllll}
$\mathrm{C}(26)$ & $51(1)$ & $40(1)$ & $30(1)$ & $-4(1)$ & $-18(1)$ & $-4(1)$ \\
$\mathrm{C}(27)$ & $46(1)$ & $30(1)$ & $29(1)$ & $-6(1)$ & $-9(1)$ & $-5(1)$ \\
$\mathrm{C}(28)$ & $31(1)$ & $28(1)$ & $24(1)$ & $1(1)$ & $-4(1)$ & $-6(1)$ \\
$\mathrm{C}(29)$ & $31(1)$ & $35(1)$ & $29(1)$ & $-2(1)$ & $-10(1)$ & $-9(1)$ \\
$\mathrm{C}(30)$ & $66(2)$ & $38(1)$ & $45(1)$ & $-7(1)$ & $-16(1)$ & $-18(1)$ \\
$\mathrm{C}(31)$ & $47(1)$ & $54(2)$ & $28(1)$ & $-3(1)$ & $-14(1)$ & $-14(1)$ \\
$\mathrm{C}(32)$ & $29(1)$ & $60(2)$ & $50(2)$ & $5(1)$ & $-15(1)$ & $-8(1)$ \\
\hline
\end{tabular}


Table S8. Hydrogen coordinates $\left(\mathrm{x} 10^{4}\right)$ and isotropic displacement parameters $\left(\AA^{2} \times 10^{3}\right)$ for 2.

\begin{tabular}{|c|c|c|c|c|}
\hline & $\mathrm{x}$ & $\mathrm{y}$ & z & $\mathrm{U}(\mathrm{eq})$ \\
\hline $\mathrm{H}(3 \mathrm{~A})$ & 6036 & 3959 & 4580 & 43 \\
\hline $\mathrm{H}(4 \mathrm{~A})$ & 6716 & 2380 & 3791 & 50 \\
\hline $\mathrm{H}(5 \mathrm{~A})$ & 7780 & 2685 & 2412 & 45 \\
\hline $\mathrm{H}(8 \mathrm{~A})$ & 6895 & 4990 & 706 & 75 \\
\hline $\mathrm{H}(8 \mathrm{~B})$ & 8171 & 5412 & 170 & 75 \\
\hline $\mathrm{H}(8 \mathrm{C})$ & 7441 & 6154 & 908 & 75 \\
\hline $\mathrm{H}(9 \mathrm{~A})$ & 10120 & 4796 & 1977 & 78 \\
\hline H(9B) & 9384 & 6038 & 1672 & 78 \\
\hline $\mathrm{H}(9 \mathrm{C})$ & 10200 & 5289 & 968 & 78 \\
\hline $\mathrm{H}(10 \mathrm{~A})$ & 8179 & 3065 & 984 & 81 \\
\hline $\mathrm{H}(10 \mathrm{~B})$ & 9429 & 2968 & 1487 & 81 \\
\hline $\mathrm{H}(10 \mathrm{C})$ & 9440 & 3599 & 513 & 81 \\
\hline $\mathrm{H}(13 \mathrm{~A})$ & 2593 & 8933 & 4974 & 43 \\
\hline $\mathrm{H}(14 \mathrm{~A})$ & 1139 & 10447 & 4442 & 49 \\
\hline $\mathrm{H}(15 \mathrm{~A})$ & 1595 & 11489 & 3097 & 46 \\
\hline $\mathrm{H}(18 \mathrm{~A})$ & 4561 & 10007 & 1211 & 84 \\
\hline $\mathrm{H}(18 \mathrm{~B})$ & 3913 & 11051 & 582 & 84 \\
\hline $\mathrm{H}(18 \mathrm{C})$ & 3054 & 10127 & 1154 & 84 \\
\hline $\mathrm{H}(19 \mathrm{~A})$ & 5536 & 11378 & 2003 & 81 \\
\hline $\mathrm{H}(19 \mathrm{~B})$ & 4674 & 12466 & 2374 & 81 \\
\hline $\mathrm{H}(19 \mathrm{C})$ & 4986 & 12444 & 1347 & 81 \\
\hline $\mathrm{H}(20 \mathrm{~A})$ & 2384 & 12813 & 2135 & 94 \\
\hline $\mathrm{H}(20 \mathrm{~B})$ & 1738 & 11923 & 1650 & 94 \\
\hline $\mathrm{H}(20 \mathrm{C})$ & 2746 & 12743 & 1117 & 94 \\
\hline $\mathrm{H}(25 \mathrm{~A})$ & 7437 & 5848 & 5011 & 42 \\
\hline $\mathrm{H}(26 \mathrm{~A})$ & 6834 & 7491 & 5744 & 47 \\
\hline $\mathrm{H}(27 \mathrm{~A})$ & 5306 & 8945 & 5236 & 41 \\
\hline $\mathrm{H}(30 \mathrm{~A})$ & 3451 & 5072 & 2390 & 72 \\
\hline $\mathrm{H}(30 \mathrm{~B})$ & 4650 & 5003 & 1672 & 72 \\
\hline $\mathrm{H}(30 \mathrm{C})$ & 3234 & 5089 & 1388 & 72 \\
\hline
\end{tabular}




\begin{tabular}{|c|c|c|c|c|}
\hline $\mathrm{H}(31 \mathrm{~A})$ & 3579 & 6836 & 346 & 62 \\
\hline $\mathrm{H}(31 \mathrm{~B})$ & 5023 & 6742 & 576 & 62 \\
\hline $\mathrm{H}(31 \mathrm{C})$ & 4131 & 7945 & 638 & 62 \\
\hline $\mathrm{H}(32 \mathrm{~A})$ & 2036 & 6955 & 2481 & 69 \\
\hline $\mathrm{H}(32 \mathrm{~B})$ & 1791 & 6995 & 1482 & 69 \\
\hline $\mathrm{H}(32 \mathrm{C})$ & 2324 & 8087 & 1814 & 69 \\
\hline $\mathrm{H}(33 \mathrm{~A})$ & 8619 & 7274 & 3496 & 38 \\
\hline $\mathrm{H}(33 \mathrm{~B})$ & 9424 & 7642 & 2583 & 38 \\
\hline $\mathrm{H}(34 \mathrm{~A})$ & 10412 & 8550 & 3495 & 48 \\
\hline $\mathrm{H}(34 \mathrm{~B})$ & 9094 & 8864 & 4085 & 48 \\
\hline $\mathrm{H}(35 \mathrm{~A})$ & 9277 & 10693 & 3090 & 63 \\
\hline $\mathrm{H}(35 \mathrm{~B})$ & 9753 & 9974 & 2269 & 63 \\
\hline $\mathrm{H}(36 \mathrm{~A})$ & 7233 & 10256 & 3124 & 49 \\
\hline $\mathrm{H}(36 \mathrm{~B})$ & 7631 & 10266 & 2096 & 49 \\
\hline $\mathrm{H}(33 \mathrm{C})$ & 9394 & 7918 & 2210 & 49 \\
\hline $\mathrm{H}(33 \mathrm{D})$ & 9004 & 7331 & 3182 & 49 \\
\hline $\mathrm{H}(34 \mathrm{C})$ & 9951 & 8612 & 3732 & 80 \\
\hline $\mathrm{H}(34 \mathrm{D})$ & 10481 & 9093 & 2765 & 80 \\
\hline $\mathrm{H}(35 \mathrm{C})$ & 9293 & 10594 & 2798 & 48 \\
\hline $\mathrm{H}(35 \mathrm{D})$ & 8940 & 10199 & 3812 & 48 \\
\hline $\mathrm{H}(36 \mathrm{C})$ & 7019 & 9859 & 3580 & 38 \\
\hline $\mathrm{H}(36 \mathrm{D})$ & 7314 & 10425 & 2590 & 38 \\
\hline $\mathrm{H}(37 \mathrm{~A})$ & 9118 & 8246 & 497 & 65 \\
\hline $\mathrm{H}(38 \mathrm{~A})$ & 7803 & 9986 & 398 & 56 \\
\hline $\mathrm{H}(39 \mathrm{~A})$ & 8684 & 11737 & -130 & 61 \\
\hline $\mathrm{H}(37 \mathrm{~B})$ & 10101 & 7996 & 443 & 64 \\
\hline $\mathrm{H}(38 \mathrm{~B})$ & 8160 & 9124 & 458 & 63 \\
\hline $\mathrm{H}(39 \mathrm{~B})$ & 8031 & 11132 & 57 & 66 \\
\hline $\mathrm{H}(40 \mathrm{~A})$ & 783 & 5679 & 3644 & 49 \\
\hline $\mathrm{H}(41 \mathrm{~A})$ & 1113 & 6806 & 4731 & 62 \\
\hline $\mathrm{H}(42 \mathrm{~A})$ & 328 & 6273 & 6173 & 64 \\
\hline $\mathrm{H}(43 \mathrm{~A})$ & -787 & 4612 & 6528 & 56 \\
\hline $\mathrm{H}(44 \mathrm{~A})$ & -1117 & 3485 & 5440 & 53 \\
\hline $\mathrm{H}(45 \mathrm{~A})$ & -332 & 4018 & 3998 & 57 \\
\hline
\end{tabular}




\subsection{Experimental Procedure for Structure 3}

X-Ray Intensity data were collected at $100 \mathrm{~K}$ on a Bruker DUO diffractometer using MoK $\alpha$ radiation $(\lambda=0.71073 \AA)$ and an APEXII CCD area detector.

Raw data frames were read by program $\mathrm{SAINT}^{7}$ and integrated using 3D profiling algorithms. The resulting data were reduced to produce hkl reflections and their intensities and estimated standard deviations. The data were corrected for Lorentz and polarization effects and numerical absorption corrections were applied based on indexed and measured faces.

The structure was solved and refined in SHELXTL2014, using full-matrix least-squares refinement. The non-H atoms were refined with anisotropic thermal parameters and all of the $\mathrm{H}$ atoms were calculated in idealized positions and refined riding on their parent atoms. In the final cycle of refinement, 12169 reflections (of which 9091 are observed with I $>2 \sigma(\mathrm{I})$ ) were used to refine 631 parameters and the resulting $\mathrm{R}_{1}, \mathrm{wR}_{2}$ and $\mathrm{S}$ (goodness of fit) were $2.87 \%, 5.31 \%$ and 0.925 , respectively. The refinement was carried out by minimizing the $\mathrm{wR}_{2}$ function using $\mathrm{F}^{2}$ rather than $F$ values. $R_{1}$ is calculated to provide a reference to the conventional $R$ value but its function is not minimized. 


\subsection{Crystal structure of 3}

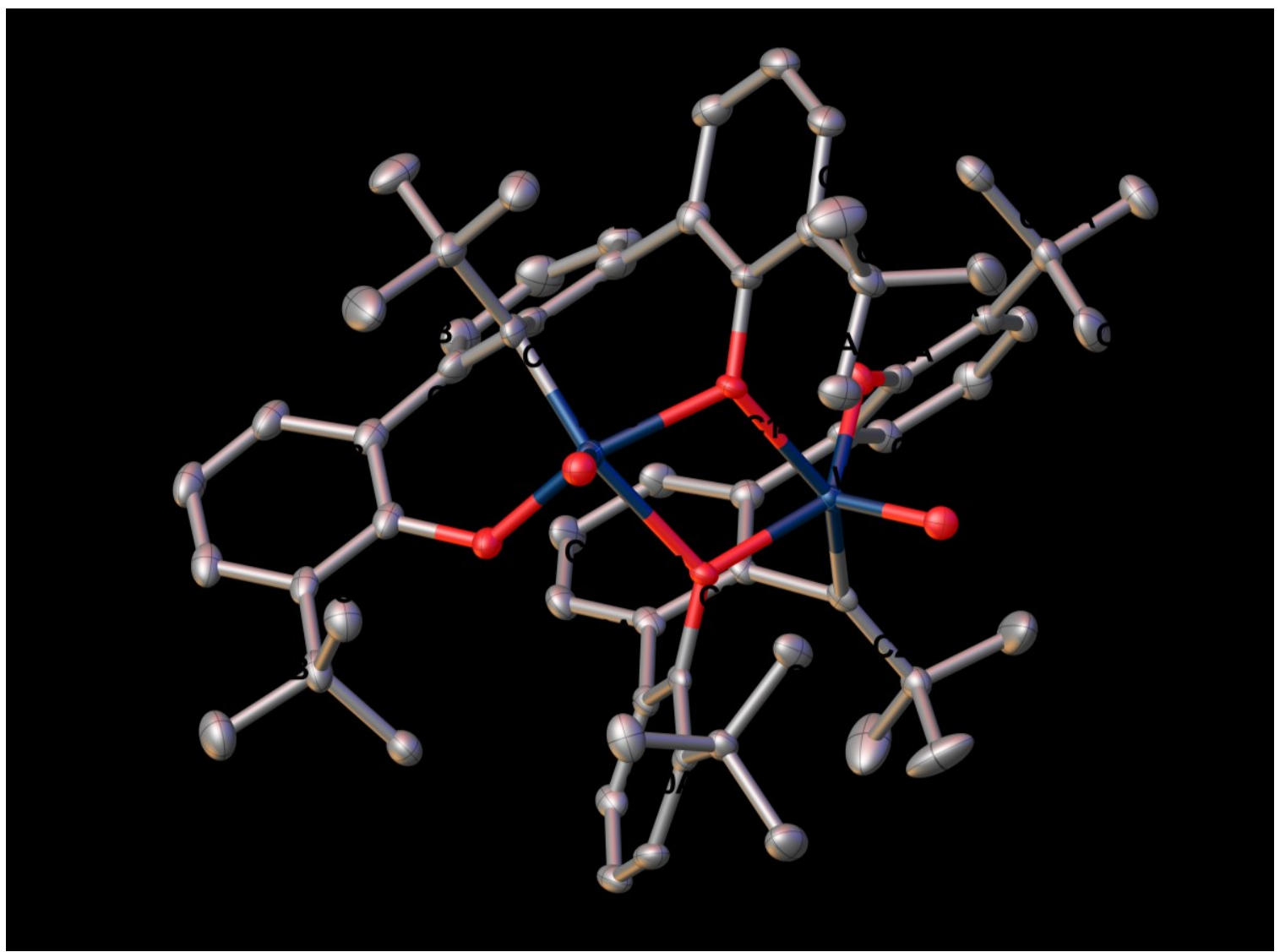

Figure S29. Molecular structure of 3. Ellipsoids shown at $50 \%$ probability level and hydrogens removed for clarity.

Table S9. Crystal data and structure refinement for 3.

Identification code

Empirical formula

Formula weight

Temperature

Wavelength

Crystal system

Space group

Unit cell dimensions

Volume

Z

Density (calculated) stella6

C62 H72 O6 W2

1280.89

100(2) K

$0.71073 \AA$

Monoclinic

$\mathrm{P} 2{ }_{1} / \mathrm{n}$

$\mathrm{a}=15.3264(5) \AA$

$\alpha=90^{\circ}$.

$\mathrm{b}=18.7530(6) \AA$

$\beta=103.3620(6)^{\circ}$.

$c=18.9589(6) \AA$

$\gamma=90^{\circ}$.
4

$1.605 \mathrm{Mg} / \mathrm{m}^{3}$ 


\begin{tabular}{|c|c|}
\hline Absorption coefficient & $4.388 \mathrm{~mm}^{-1}$ \\
\hline $\mathrm{F}(000)$ & 2560 \\
\hline Crystal size & $0.093 \times 0.073 \times 0.047 \mathrm{~mm}^{3}$ \\
\hline Theta range for data collection & 1.545 to $27.497^{\circ}$. \\
\hline Index ranges & $-19 \leq \mathrm{h} \leq 19,-24 \leq \mathrm{k} \leq 24,-24 \leq \mathrm{l} \leq 24$ \\
\hline Reflections collected & 65589 \\
\hline Independent reflections & $12169[\mathrm{R}(\mathrm{int})=0.0677]$ \\
\hline Completeness to theta $=25.242^{\circ}$ & $100.0 \%$ \\
\hline Absorption correction & Analytical \\
\hline Max. and min. transmission & 0.8399 and 0.7546 \\
\hline Refinement method & Full-matrix least-squares on $\mathrm{F}^{2}$ \\
\hline Data / restraints / parameters & $12169 / 696 / 631$ \\
\hline Goodness-of-fit on $\mathrm{F}^{2}$ & 0.925 \\
\hline Final R indices $[\mathrm{I}>2 \operatorname{sigma}(\mathrm{I})]$ & $\mathrm{R} 1=0.0287, \mathrm{wR} 2=0.0531[9091]$ \\
\hline $\mathrm{R}$ indices (all data) & $\mathrm{R} 1=0.0506, \mathrm{wR} 2=0.0573$ \\
\hline Extinction coefficient & $\mathrm{n} / \mathrm{a}$ \\
\hline Largest diff. peak and hole & 1.318 and -1.441 e. $\AA^{-3}$ \\
\hline $\mathrm{R} 1=\sum\left(|| \mathrm{F}_{\mathrm{O}}|-| \mathrm{F}_{\mathrm{c}} \mid\right) / \sum\left|\mathrm{F}_{\mathrm{o}}\right|$ & $\mathrm{wR} 2=\left[\Sigma\left[\mathrm{w}\left(\mathrm{F}_{\mathrm{o}}^{2}-\mathrm{F}_{\mathrm{c}}^{2}\right)^{2}\right] / \Sigma\left[\mathrm{w}\left(\mathrm{F}_{\mathrm{o}}^{2}\right)^{2}\right]\right]^{1 / 2}$ \\
\hline $\mathrm{S}=\left[\Sigma\left[\mathrm{w}\left(\mathrm{F}_{\mathrm{o}}^{2}-\mathrm{F}_{\mathrm{c}}^{2}\right)^{2}\right] /(\mathrm{n}-\mathrm{p})\right]^{1 / 2}$ & $\mathrm{w}=1 /\left[\sigma^{2}\left(\mathrm{~F}_{\mathrm{o}}^{2}\right)+(\mathrm{m} * \mathrm{p})^{2}+\mathrm{n} * \mathrm{p}\right], \mathrm{p}=\left[\max \left(\mathrm{F}_{\mathrm{o}}^{2}, 0\right)+2^{*} \mathrm{~F}_{\mathrm{c}}^{2}\right] / 3, \mathrm{~m} \& \mathrm{n}$ are constants. \\
\hline
\end{tabular}


Table S10. Atomic coordinates $\left(\mathrm{x} 10^{4}\right)$ and equivalent isotropic displacement parameters $\left(\AA^{2} \mathrm{x}\right.$ $10^{3}$ ) for 3. $U(e q)$ is defined as one third of the trace of the orthogonalized $U^{i j}$ tensor.

\begin{tabular}{|c|c|c|c|c|}
\hline & $\mathrm{x}$ & $\mathrm{y}$ & z & $\mathrm{U}(\mathrm{eq})$ \\
\hline $\mathrm{W}(1 \mathrm{~A})$ & 2352(1) & $2357(1)$ & $9176(1)$ & $14(1)$ \\
\hline $\mathrm{W}(1 \mathrm{~B})$ & $2055(1)$ & $3499(1)$ & $10574(1)$ & $16(1)$ \\
\hline $\mathrm{O}(1 \mathrm{~A})$ & $2225(2)$ & $3420(1)$ & $9435(1)$ & $14(1)$ \\
\hline $\mathrm{O}(1 \mathrm{~B})$ & 1904(2) & $2462(1)$ & $10208(1)$ & $16(1)$ \\
\hline $\mathrm{O}(2 \mathrm{~A})$ & $1466(2)$ & 2099(1) & $8509(1)$ & $18(1)$ \\
\hline $\mathrm{O}(2 \mathrm{~B})$ & $1037(2)$ & $3864(1)$ & $10553(1)$ & $22(1)$ \\
\hline $\mathrm{O}(3 \mathrm{~A})$ & 2951(2) & $1499(1)$ & $9623(1)$ & $17(1)$ \\
\hline $\mathrm{O}(3 \mathrm{~B})$ & $2928(2)$ & $4262(1)$ & $10657(1)$ & $20(1)$ \\
\hline$C(1 \mathrm{~A})$ & $3219(2)$ & $2562(2)$ & $8644(2)$ & $15(1)$ \\
\hline $\mathrm{C}(1 \mathrm{~B})$ & 2442(3) & $3230(2)$ & $11554(2)$ & $20(1)$ \\
\hline $\mathrm{C}(2 \mathrm{~A})$ & $3972(2)$ & 2782(2) & $9269(2)$ & $15(1)$ \\
\hline $\mathrm{C}(2 \mathrm{~B})$ & $3327(3)$ & $2896(2)$ & $11523(2)$ & $22(1)$ \\
\hline$C(3 \mathrm{~A})$ & $4083(2)$ & $3503(2)$ & $9482(2)$ & $17(1)$ \\
\hline$C(3 B)$ & $3378(3)$ & 2153(2) & $11381(2)$ & $24(1)$ \\
\hline$C(4 A)$ & $4838(3)$ & $3697(2)$ & $10012(2)$ & $21(1)$ \\
\hline$C(4 B)$ & $4209(3)$ & $1833(2)$ & $11472(2)$ & $28(1)$ \\
\hline$C(5 \mathrm{~A})$ & $5473(3)$ & $3198(2)$ & $10317(2)$ & $25(1)$ \\
\hline$C(5 B)$ & 4982(3) & $2236(2)$ & $11709(2)$ & $33(1)$ \\
\hline$C(6 \mathrm{~A})$ & $5347(2)$ & $2486(2)$ & $10132(2)$ & $22(1)$ \\
\hline$C(6 B)$ & $4939(3)$ & 2964(2) & $11795(2)$ & $30(1)$ \\
\hline$C(7 A)$ & $4584(2)$ & $2265(2)$ & $9618(2)$ & $18(1)$ \\
\hline $\mathrm{C}(7 \mathrm{~B})$ & $4116(3)$ & $3317(2)$ & 11681(2) & $24(1)$ \\
\hline$C(8 \mathrm{~A})$ & $3437(2)$ & $4046(2)$ & $9108(2)$ & $16(1)$ \\
\hline $\mathrm{C}(8 \mathrm{~B})$ & $2559(3)$ & $1709(2)$ & $11228(2)$ & $21(1)$ \\
\hline $\mathrm{C}(9 \mathrm{~A})$ & $2507(2)$ & $3982(2)$ & $9044(2)$ & $15(1)$ \\
\hline $\mathrm{C}(9 \mathrm{~B})$ & $1808(3)$ & $1886(2)$ & $10666(2)$ & $18(1)$ \\
\hline$C(10 A)$ & 1893(2) & $4464(2)$ & $8630(2)$ & $15(1)$ \\
\hline $\mathrm{C}(10 \mathrm{~B})$ & 993(3) & $1507(2)$ & $10569(2)$ & $21(1)$ \\
\hline$C(11 \mathrm{~A})$ & $2279(3)$ & $5022(2)$ & $8321(2)$ & $21(1)$ \\
\hline$C(11 B)$ & 1018(3) & $911(2)$ & $11026(2)$ & $24(1)$ \\
\hline$C(12 A)$ & $3179(3)$ & $5113(2)$ & $8396(2)$ & $21(1)$ \\
\hline
\end{tabular}




\begin{tabular}{|c|c|c|c|c|}
\hline$C(12 B)$ & 1756(3) & $710(2)$ & $11541(2)$ & $27(1)$ \\
\hline$C(13 A)$ & $3769(3)$ & $4626(2)$ & $8789(2)$ & $20(1)$ \\
\hline$C(13 B)$ & 2524(3) & $1116(2)$ & $11647(2)$ & $26(1)$ \\
\hline $\mathrm{C}(14 \mathrm{~A})$ & 4451(2) & 1501(2) & $9431(2)$ & $18(1)$ \\
\hline$C(14 B)$ & 4085(3) & $4103(2)$ & $11754(2)$ & $23(1)$ \\
\hline$C(15 A)$ & $3651(2)$ & $1140(2)$ & $9443(2)$ & $17(1)$ \\
\hline$C(15 B)$ & $3497(3)$ & $4548(2)$ & $11258(2)$ & $22(1)$ \\
\hline$C(16 A)$ & $3552(3)$ & $398(2)$ & $9279(2)$ & $19(1)$ \\
\hline$C(16 B)$ & $3497(3)$ & $5300(2)$ & $11356(2)$ & $21(1)$ \\
\hline$C(17 A)$ & $4276(3)$ & $67(2)$ & $9096(2)$ & $23(1)$ \\
\hline $\mathrm{C}(17 \mathrm{~B})$ & 4129(3) & $5573(2)$ & $11938(2)$ & $26(1)$ \\
\hline $\mathrm{C}(18 \mathrm{~A})$ & $5066(3)$ & $412(2)$ & $9067(2)$ & $24(1)$ \\
\hline$C(18 B)$ & $4726(3)$ & $5144(2)$ & $12418(2)$ & $29(1)$ \\
\hline$C(19 A)$ & $5148(3)$ & $1127(2)$ & $9238(2)$ & $21(1)$ \\
\hline$C(19 B)$ & $4700(3)$ & $4415(2)$ & $12334(2)$ & $28(1)$ \\
\hline$C(20 A)$ & $3343(3)$ & $2546(2)$ & $7865(2)$ & $19(1)$ \\
\hline$C(20 B)$ & $2136(3)$ & $3265(2)$ & $12269(2)$ & $27(1)$ \\
\hline$C(21 B)$ & 1299(3) & $2808(2)$ & $12204(2)$ & $32(1)$ \\
\hline$C(21 \mathrm{~A})$ & $3310(4)$ & 1781(3) & $7610(3)$ & $50(2)$ \\
\hline$C(22 B)$ & $2875(3)$ & $3019(3)$ & $12911(2)$ & $40(1)$ \\
\hline$C(22 \mathrm{~A})$ & $2568(3)$ & 2945(3) & $7389(3)$ & $51(2)$ \\
\hline$C(23 B)$ & $1905(4)$ & $4047(2)$ & $12398(3)$ & $46(1)$ \\
\hline$C(23 \mathrm{~A})$ & $4217(3)$ & 2884(3) & 7806(3) & $54(2)$ \\
\hline$C(24 A)$ & $855(2)$ & $4456(2)$ & $8502(2)$ & $19(1)$ \\
\hline$C(24 B)$ & $72(3)$ & $1665(2)$ & $10044(2)$ & $25(1)$ \\
\hline$C(25 \mathrm{~A})$ & $575(3)$ & 4998(2) & $9008(2)$ & $29(1)$ \\
\hline$C(25 B)$ & $-642(3)$ & 1699(3) & 10494(3) & $41(1)$ \\
\hline$C(26 B)$ & 1(3) & $2362(2)$ & $9634(2)$ & $26(1)$ \\
\hline$C(26 \mathrm{~A})$ & $429(3)$ & $4674(2)$ & $7710(2)$ & $31(1)$ \\
\hline$C(27 \mathrm{~A})$ & $457(3)$ & $3729(2)$ & $8607(2)$ & $24(1)$ \\
\hline$C(27 B)$ & $-152(3)$ & $1056(2)$ & $9485(3)$ & $39(1)$ \\
\hline$C(28 \mathrm{~A})$ & 2691(3) & $-17(2)$ & $9298(2)$ & $20(1)$ \\
\hline$C(28 B)$ & $2818(3)$ & $5795(2)$ & $10868(2)$ & $25(1)$ \\
\hline$C(29 A)$ & $2472(3)$ & $27(2)$ & $10047(2)$ & $24(1)$ \\
\hline$C(29 B)$ & 2814(3) & $5698(2)$ & $10067(2)$ & $25(1)$ \\
\hline$C(30 A)$ & 1911(3) & $275(2)$ & $8710(2)$ & $32(1)$ \\
\hline
\end{tabular}


C(30B)

$\mathrm{C}(31 \mathrm{~B})$

$\mathrm{C}(31 \mathrm{~A})$
3021(3)

1877(3)

2793(3)
6583(2)

5638(2)

$-807(2)$
11050(3)

10988(2)

9129(3)
36(1)

29(1)

31(1) 
Table S11. Bond lengths $[\AA]$ and angles $\left[{ }^{\circ}\right]$ for 3 .

\begin{tabular}{|c|c|}
\hline $\mathrm{W}(1 \mathrm{~A})-\mathrm{O}(2 \mathrm{~A})$ & $1.698(2)$ \\
\hline $\mathrm{W}(1 \mathrm{~A})-\mathrm{C}(1 \mathrm{~A})$ & $1.884(4)$ \\
\hline $\mathrm{W}(1 \mathrm{~A})-\mathrm{O}(3 \mathrm{~A})$ & $1.948(2)$ \\
\hline $\mathrm{W}(1 \mathrm{~A})-\mathrm{O}(1 \mathrm{~A})$ & $2.073(2)$ \\
\hline $\mathrm{W}(1 \mathrm{~A})-\mathrm{O}(1 \mathrm{~B})$ & $2.227(3)$ \\
\hline $\mathrm{W}(1 \mathrm{~A})-\mathrm{C}(2 \mathrm{~A})$ & $2.576(3)$ \\
\hline $\mathrm{W}(1 \mathrm{~B})-\mathrm{O}(2 \mathrm{~B})$ & $1.696(3)$ \\
\hline $\mathrm{W}(1 \mathrm{~B})-\mathrm{C}(1 \mathrm{~B})$ & $1.885(4)$ \\
\hline $\mathrm{W}(1 \mathrm{~B})-\mathrm{O}(3 \mathrm{~B})$ & $1.939(3)$ \\
\hline $\mathrm{W}(1 \mathrm{~B})-\mathrm{O}(1 \mathrm{~B})$ & $2.062(2)$ \\
\hline $\mathrm{W}(1 \mathrm{~B})-\mathrm{O}(1 \mathrm{~A})$ & $2.239(3)$ \\
\hline $\mathrm{W}(1 \mathrm{~B})-\mathrm{C}(2 \mathrm{~B})$ & $2.588(4)$ \\
\hline $\mathrm{O}(1 \mathrm{~A})-\mathrm{C}(9 \mathrm{~A})$ & $1.413(4)$ \\
\hline $\mathrm{O}(1 \mathrm{~B})-\mathrm{C}(9 \mathrm{~B})$ & $1.414(4)$ \\
\hline $\mathrm{O}(3 \mathrm{~A})-\mathrm{C}(15 \mathrm{~A})$ & $1.375(4)$ \\
\hline $\mathrm{O}(3 \mathrm{~B})-\mathrm{C}(15 \mathrm{~B})$ & $1.374(4)$ \\
\hline$C(1 A)-C(2 A)$ & $1.509(5)$ \\
\hline$C(1 A)-C(20 A)$ & $1.532(5)$ \\
\hline$C(1 B)-C(2 B)$ & $1.509(5)$ \\
\hline$C(1 B)-C(20 B)$ & $1.535(6)$ \\
\hline $\mathrm{C}(2 \mathrm{~A})-\mathrm{C}(7 \mathrm{~A})$ & $1.404(5)$ \\
\hline$C(2 A)-C(3 A)$ & $1.410(5)$ \\
\hline $\mathrm{C}(2 \mathrm{~B})-\mathrm{C}(7 \mathrm{~B})$ & $1.417(5)$ \\
\hline $\mathrm{C}(2 \mathrm{~B})-\mathrm{C}(3 \mathrm{~B})$ & $1.423(6)$ \\
\hline$C(3 A)-C(4 A)$ & $1.393(5)$ \\
\hline$C(3 A)-C(8 A)$ & $1.482(5)$ \\
\hline$C(3 B)-C(4 B)$ & $1.383(6)$ \\
\hline$C(3 B)-C(8 B)$ & $1.479(5)$ \\
\hline$C(4 A)-C(5 A)$ & $1.379(5)$ \\
\hline $\mathrm{C}(4 \mathrm{~B})-\mathrm{C}(5 \mathrm{~B})$ & $1.389(6)$ \\
\hline$C(5 A)-C(6 A)$ & $1.382(5)$ \\
\hline $\mathrm{C}(5 \mathrm{~B})-\mathrm{C}(6 \mathrm{~B})$ & $1.379(6)$ \\
\hline$C(6 A)-C(7 A)$ & $1.401(5)$ \\
\hline$C(6 B)-C(7 B)$ & $1.397(6)$ \\
\hline
\end{tabular}




\begin{tabular}{|c|c|}
\hline $\mathrm{C}(7 \mathrm{~A})-\mathrm{C}(14 \mathrm{~A})$ & $1.478(5)$ \\
\hline$C(7 B)-C(14 B)$ & $1.483(6)$ \\
\hline $\mathrm{C}(8 \mathrm{~A})-\mathrm{C}(13 \mathrm{~A})$ & $1.395(5)$ \\
\hline $\mathrm{C}(8 \mathrm{~A})-\mathrm{C}(9 \mathrm{~A})$ & $1.407(5)$ \\
\hline $\mathrm{C}(8 \mathrm{~B})-\mathrm{C}(13 \mathrm{~B})$ & $1.375(6)$ \\
\hline $\mathrm{C}(8 \mathrm{~B})-\mathrm{C}(9 \mathrm{~B})$ & $1.415(5)$ \\
\hline $\mathrm{C}(9 \mathrm{~A})-\mathrm{C}(10 \mathrm{~A})$ & $1.405(5)$ \\
\hline $\mathrm{C}(9 \mathrm{~B})-\mathrm{C}(10 \mathrm{~B})$ & $1.413(5)$ \\
\hline$C(10 A)-C(11 A)$ & $1.397(5)$ \\
\hline$C(10 A)-C(24 A)$ & $1.552(5)$ \\
\hline $\mathrm{C}(10 \mathrm{~B})-\mathrm{C}(11 \mathrm{~B})$ & $1.408(5)$ \\
\hline $\mathrm{C}(10 \mathrm{~B})-\mathrm{C}(24 \mathrm{~B})$ & $1.555(5)$ \\
\hline $\mathrm{C}(11 \mathrm{~A})-\mathrm{C}(12 \mathrm{~A})$ & $1.365(5)$ \\
\hline $\mathrm{C}(11 \mathrm{~B})-\mathrm{C}(12 \mathrm{~B})$ & $1.366(6)$ \\
\hline$C(12 A)-C(13 A)$ & $1.378(5)$ \\
\hline $\mathrm{C}(12 \mathrm{~B})-\mathrm{C}(13 \mathrm{~B})$ & $1.379(6)$ \\
\hline $\mathrm{C}(14 \mathrm{~A})-\mathrm{C}(19 \mathrm{~A})$ & $1.397(5)$ \\
\hline $\mathrm{C}(14 \mathrm{~A})-\mathrm{C}(15 \mathrm{~A})$ & $1.406(5)$ \\
\hline$C(14 B)-C(19 B)$ & $1.400(5)$ \\
\hline$C(14 B)-C(15 B)$ & $1.415(5)$ \\
\hline$C(15 A)-C(16 A)$ & $1.426(5)$ \\
\hline $\mathrm{C}(15 \mathrm{~B})-\mathrm{C}(16 \mathrm{~B})$ & $1.422(6)$ \\
\hline$C(16 A)-C(17 A)$ & $1.384(5)$ \\
\hline$C(16 A)-C(28 A)$ & $1.541(5)$ \\
\hline$C(16 B)-C(17 B)$ & $1.388(5)$ \\
\hline $\mathrm{C}(16 \mathrm{~B})-\mathrm{C}(28 \mathrm{~B})$ & $1.535(6)$ \\
\hline $\mathrm{C}(17 \mathrm{~A})-\mathrm{C}(18 \mathrm{~A})$ & $1.385(5)$ \\
\hline $\mathrm{C}(17 \mathrm{~B})-\mathrm{C}(18 \mathrm{~B})$ & $1.388(6)$ \\
\hline $\mathrm{C}(18 \mathrm{~A})-\mathrm{C}(19 \mathrm{~A})$ & $1.379(5)$ \\
\hline $\mathrm{C}(18 \mathrm{~B})-\mathrm{C}(19 \mathrm{~B})$ & $1.376(6)$ \\
\hline$C(20 A)-C(21 A)$ & $1.510(6)$ \\
\hline$C(20 A)-C(23 A)$ & $1.509(6)$ \\
\hline$C(20 A)-C(22 A)$ & $1.514(6)$ \\
\hline $\mathrm{C}(20 \mathrm{~B})-\mathrm{C}(21 \mathrm{~B})$ & $1.524(6)$ \\
\hline $\mathrm{C}(20 \mathrm{~B})-\mathrm{C}(22 \mathrm{~B})$ & $1.529(6)$ \\
\hline$C(20 B)-C(23 B)$ & $1.541(6)$ \\
\hline
\end{tabular}




\begin{tabular}{|c|c|}
\hline $\mathrm{C}(24 \mathrm{~A})-\mathrm{C}(27 \mathrm{~A})$ & $1.525(5)$ \\
\hline$C(24 \mathrm{~A})-\mathrm{C}(25 \mathrm{~A})$ & $1.527(5)$ \\
\hline$C(24 A)-C(26 A)$ & $1.548(5)$ \\
\hline$C(24 B)-C(26 B)$ & $1.511(5)$ \\
\hline $\mathrm{C}(24 \mathrm{~B})-\mathrm{C}(25 \mathrm{~B})$ & $1.536(6)$ \\
\hline $\mathrm{C}(24 \mathrm{~B})-\mathrm{C}(27 \mathrm{~B})$ & $1.543(6)$ \\
\hline $\mathrm{C}(28 \mathrm{~A})-\mathrm{C}(31 \mathrm{~A})$ & $1.532(5)$ \\
\hline$C(28 \mathrm{~A})-\mathrm{C}(29 \mathrm{~A})$ & $1.534(6)$ \\
\hline $\mathrm{C}(28 \mathrm{~A})-\mathrm{C}(30 \mathrm{~A})$ & $1.534(5)$ \\
\hline $\mathrm{C}(28 \mathrm{~B})-\mathrm{C}(29 \mathrm{~B})$ & $1.527(6)$ \\
\hline $\mathrm{C}(28 \mathrm{~B})-\mathrm{C}(30 \mathrm{~B})$ & $1.534(6)$ \\
\hline $\mathrm{C}(28 \mathrm{~B})-\mathrm{C}(31 \mathrm{~B})$ & $1.541(5)$ \\
\hline $\mathrm{O}(2 \mathrm{~A})-\mathrm{W}(1 \mathrm{~A})-\mathrm{C}(1 \mathrm{~A})$ & $101.62(14)$ \\
\hline $\mathrm{O}(2 \mathrm{~A})-\mathrm{W}(1 \mathrm{~A})-\mathrm{O}(3 \mathrm{~A})$ & 107.71(11) \\
\hline$C(1 \mathrm{~A})-\mathrm{W}(1 \mathrm{~A})-\mathrm{O}(3 \mathrm{~A})$ & $94.71(13)$ \\
\hline $\mathrm{O}(2 \mathrm{~A})-\mathrm{W}(1 \mathrm{~A})-\mathrm{O}(1 \mathrm{~A})$ & $110.40(11)$ \\
\hline$C(1 \mathrm{~A})-\mathrm{W}(1 \mathrm{~A})-\mathrm{O}(1 \mathrm{~A})$ & $92.65(13)$ \\
\hline $\mathrm{O}(3 \mathrm{~A})-\mathrm{W}(1 \mathrm{~A})-\mathrm{O}(1 \mathrm{~A})$ & $138.75(10)$ \\
\hline $\mathrm{O}(2 \mathrm{~A})-\mathrm{W}(1 \mathrm{~A})-\mathrm{O}(1 \mathrm{~B})$ & $108.88(11)$ \\
\hline $\mathrm{C}(1 \mathrm{~A})-\mathrm{W}(1 \mathrm{~A})-\mathrm{O}(1 \mathrm{~B})$ & $148.32(13)$ \\
\hline $\mathrm{O}(3 \mathrm{~A})-\mathrm{W}(1 \mathrm{~A})-\mathrm{O}(1 \mathrm{~B})$ & $84.25(10)$ \\
\hline $\mathrm{O}(1 \mathrm{~A})-\mathrm{W}(1 \mathrm{~A})-\mathrm{O}(1 \mathrm{~B})$ & $69.06(9)$ \\
\hline $\mathrm{O}(2 \mathrm{~A})-\mathrm{W}(1 \mathrm{~A})-\mathrm{C}(2 \mathrm{~A})$ & $137.06(12)$ \\
\hline$C(1 \mathrm{~A})-\mathrm{W}(1 \mathrm{~A})-\mathrm{C}(2 \mathrm{~A})$ & $35.45(14)$ \\
\hline $\mathrm{O}(3 \mathrm{~A})-\mathrm{W}(1 \mathrm{~A})-\mathrm{C}(2 \mathrm{~A})$ & $82.85(11)$ \\
\hline $\mathrm{O}(1 \mathrm{~A})-\mathrm{W}(1 \mathrm{~A})-\mathrm{C}(2 \mathrm{~A})$ & $80.06(10)$ \\
\hline $\mathrm{O}(1 \mathrm{~B})-\mathrm{W}(1 \mathrm{~A})-\mathrm{C}(2 \mathrm{~A})$ & 113.61(11) \\
\hline $\mathrm{O}(2 \mathrm{~B})-\mathrm{W}(1 \mathrm{~B})-\mathrm{C}(1 \mathrm{~B})$ & $102.00(15)$ \\
\hline $\mathrm{O}(2 \mathrm{~B})-\mathrm{W}(1 \mathrm{~B})-\mathrm{O}(3 \mathrm{~B})$ & $108.56(12)$ \\
\hline $\mathrm{C}(1 \mathrm{~B})-\mathrm{W}(1 \mathrm{~B})-\mathrm{O}(3 \mathrm{~B})$ & $93.68(14)$ \\
\hline $\mathrm{O}(2 \mathrm{~B})-\mathrm{W}(1 \mathrm{~B})-\mathrm{O}(1 \mathrm{~B})$ & $109.97(11)$ \\
\hline $\mathrm{C}(1 \mathrm{~B})-\mathrm{W}(1 \mathrm{~B})-\mathrm{O}(1 \mathrm{~B})$ & $93.66(14)$ \\
\hline $\mathrm{O}(3 \mathrm{~B})-\mathrm{W}(1 \mathrm{~B})-\mathrm{O}(1 \mathrm{~B})$ & $138.20(11)$ \\
\hline $\mathrm{O}(2 \mathrm{~B})-\mathrm{W}(1 \mathrm{~B})-\mathrm{O}(1 \mathrm{~A})$ & $108.45(11)$ \\
\hline $\mathrm{C}(1 \mathrm{~B})-\mathrm{W}(1 \mathrm{~B})-\mathrm{O}(1 \mathrm{~A})$ & $148.57(14)$ \\
\hline
\end{tabular}




\begin{tabular}{|c|c|}
\hline $\mathrm{O}(3 \mathrm{~B})-\mathrm{W}(1 \mathrm{~B})-\mathrm{O}(1 \mathrm{~A})$ & $84.0(1)$ \\
\hline $\mathrm{O}(1 \mathrm{~B})-\mathrm{W}(1 \mathrm{~B})-\mathrm{O}(1 \mathrm{~A})$ & $69.02(9)$ \\
\hline $\mathrm{O}(2 \mathrm{~B})-\mathrm{W}(1 \mathrm{~B})-\mathrm{C}(2 \mathrm{~B})$ & $137.17(13)$ \\
\hline $\mathrm{C}(1 \mathrm{~B})-\mathrm{W}(1 \mathrm{~B})-\mathrm{C}(2 \mathrm{~B})$ & $35.18(15)$ \\
\hline $\mathrm{O}(3 \mathrm{~B})-\mathrm{W}(1 \mathrm{~B})-\mathrm{C}(2 \mathrm{~B})$ & $82.64(12)$ \\
\hline $\mathrm{O}(1 \mathrm{~B})-\mathrm{W}(1 \mathrm{~B})-\mathrm{C}(2 \mathrm{~B})$ & $80.14(11)$ \\
\hline $\mathrm{O}(1 \mathrm{~A})-\mathrm{W}(1 \mathrm{~B})-\mathrm{C}(2 \mathrm{~B})$ & $113.86(11)$ \\
\hline $\mathrm{C}(9 \mathrm{~A})-\mathrm{O}(1 \mathrm{~A})-\mathrm{W}(1 \mathrm{~A})$ & $122.5(2)$ \\
\hline $\mathrm{C}(9 \mathrm{~A})-\mathrm{O}(1 \mathrm{~A})-\mathrm{W}(1 \mathrm{~B})$ & $125.1(2)$ \\
\hline $\mathrm{W}(1 \mathrm{~A})-\mathrm{O}(1 \mathrm{~A})-\mathrm{W}(1 \mathrm{~B})$ & $109.3(1)$ \\
\hline $\mathrm{C}(9 \mathrm{~B})-\mathrm{O}(1 \mathrm{~B})-\mathrm{W}(1 \mathrm{~B})$ & $122.2(2)$ \\
\hline $\mathrm{C}(9 \mathrm{~B})-\mathrm{O}(1 \mathrm{~B})-\mathrm{W}(1 \mathrm{~A})$ & $124.7(2)$ \\
\hline $\mathrm{W}(1 \mathrm{~B})-\mathrm{O}(1 \mathrm{~B})-\mathrm{W}(1 \mathrm{~A})$ & $110.18(11)$ \\
\hline $\mathrm{C}(15 \mathrm{~A})-\mathrm{O}(3 \mathrm{~A})-\mathrm{W}(1 \mathrm{~A})$ & $127.8(2)$ \\
\hline $\mathrm{C}(15 \mathrm{~B})-\mathrm{O}(3 \mathrm{~B})-\mathrm{W}(1 \mathrm{~B})$ & $130.4(2)$ \\
\hline$C(2 A)-C(1 A)-C(20 A)$ & $121.3(3)$ \\
\hline$C(2 A)-C(1 A)-W(1 A)$ & $98.2(2)$ \\
\hline$C(20 A)-C(1 A)-W(1 A)$ & $140.5(3)$ \\
\hline $\mathrm{C}(2 \mathrm{~B})-\mathrm{C}(1 \mathrm{~B})-\mathrm{C}(20 \mathrm{~B})$ & $120.9(3)$ \\
\hline $\mathrm{C}(2 \mathrm{~B})-\mathrm{C}(1 \mathrm{~B})-\mathrm{W}(1 \mathrm{~B})$ & $98.8(3)$ \\
\hline C(20B)-C(1B)-W(1B) & $140.3(3)$ \\
\hline$C(7 A)-C(2 A)-C(3 A)$ & $120.3(3)$ \\
\hline$C(7 A)-C(2 A)-C(1 A)$ & 119.2(3) \\
\hline$C(3 \mathrm{~A})-\mathrm{C}(2 \mathrm{~A})-\mathrm{C}(1 \mathrm{~A})$ & $120.4(3)$ \\
\hline $\mathrm{C}(7 \mathrm{~A})-\mathrm{C}(2 \mathrm{~A})-\mathrm{W}(1 \mathrm{~A})$ & $110.3(2)$ \\
\hline$C(3 A)-C(2 A)-W(1 A)$ & $111.5(2)$ \\
\hline $\mathrm{C}(1 \mathrm{~A})-\mathrm{C}(2 \mathrm{~A})-\mathrm{W}(1 \mathrm{~A})$ & $46.40(17)$ \\
\hline$C(7 B)-C(2 B)-C(3 B)$ & $120.2(4)$ \\
\hline $\mathrm{C}(7 \mathrm{~B})-\mathrm{C}(2 \mathrm{~B})-\mathrm{C}(1 \mathrm{~B})$ & $119.4(4)$ \\
\hline $\mathrm{C}(3 \mathrm{~B})-\mathrm{C}(2 \mathrm{~B})-\mathrm{C}(1 \mathrm{~B})$ & $120.2(4)$ \\
\hline $\mathrm{C}(7 \mathrm{~B})-\mathrm{C}(2 \mathrm{~B})-\mathrm{W}(1 \mathrm{~B})$ & $111.8(3)$ \\
\hline $\mathrm{C}(3 \mathrm{~B})-\mathrm{C}(2 \mathrm{~B})-\mathrm{W}(1 \mathrm{~B})$ & $111.3(3)$ \\
\hline $\mathrm{C}(1 \mathrm{~B})-\mathrm{C}(2 \mathrm{~B})-\mathrm{W}(1 \mathrm{~B})$ & $46.05(18)$ \\
\hline $\mathrm{C}(4 \mathrm{~A})-\mathrm{C}(3 \mathrm{~A})-\mathrm{C}(2 \mathrm{~A})$ & $118.8(3)$ \\
\hline $\mathrm{C}(4 \mathrm{~A})-\mathrm{C}(3 \mathrm{~A})-\mathrm{C}(8 \mathrm{~A})$ & 121.1(3) \\
\hline $\mathrm{C}(2 \mathrm{~A})-\mathrm{C}(3 \mathrm{~A})-\mathrm{C}(8 \mathrm{~A})$ & $119.9(3)$ \\
\hline
\end{tabular}




\begin{tabular}{|c|c|}
\hline $\mathrm{C}(4 \mathrm{~B})-\mathrm{C}(3 \mathrm{~B})-\mathrm{C}(2 \mathrm{~B})$ & $119.4(4)$ \\
\hline $\mathrm{C}(4 \mathrm{~B})-\mathrm{C}(3 \mathrm{~B})-\mathrm{C}(8 \mathrm{~B})$ & $119.7(4)$ \\
\hline $\mathrm{C}(2 \mathrm{~B})-\mathrm{C}(3 \mathrm{~B})-\mathrm{C}(8 \mathrm{~B})$ & $120.4(4)$ \\
\hline$C(5 A)-C(4 A)-C(3 A)$ & $120.9(4)$ \\
\hline $\mathrm{C}(3 \mathrm{~B})-\mathrm{C}(4 \mathrm{~B})-\mathrm{C}(5 \mathrm{~B})$ & $119.8(4)$ \\
\hline$C(4 A)-C(5 A)-C(6 A)$ & $120.3(4)$ \\
\hline $\mathrm{C}(6 \mathrm{~B})-\mathrm{C}(5 \mathrm{~B})-\mathrm{C}(4 \mathrm{~B})$ & $121.0(4)$ \\
\hline$C(5 A)-C(6 A)-C(7 A)$ & $120.6(4)$ \\
\hline $\mathrm{C}(5 \mathrm{~B})-\mathrm{C}(6 \mathrm{~B})-\mathrm{C}(7 \mathrm{~B})$ & $121.2(4)$ \\
\hline$C(6 A)-C(7 A)-C(2 A)$ & $118.8(3)$ \\
\hline $\mathrm{C}(6 \mathrm{~A})-\mathrm{C}(7 \mathrm{~A})-\mathrm{C}(14 \mathrm{~A})$ & $120.1(3)$ \\
\hline $\mathrm{C}(2 \mathrm{~A})-\mathrm{C}(7 \mathrm{~A})-\mathrm{C}(14 \mathrm{~A})$ & 121.1(3) \\
\hline $\mathrm{C}(6 \mathrm{~B})-\mathrm{C}(7 \mathrm{~B})-\mathrm{C}(2 \mathrm{~B})$ & $117.7(4)$ \\
\hline $\mathrm{C}(6 \mathrm{~B})-\mathrm{C}(7 \mathrm{~B})-\mathrm{C}(14 \mathrm{~B})$ & $120.3(4)$ \\
\hline $\mathrm{C}(2 \mathrm{~B})-\mathrm{C}(7 \mathrm{~B})-\mathrm{C}(14 \mathrm{~B})$ & $122.0(4)$ \\
\hline $\mathrm{C}(13 \mathrm{~A})-\mathrm{C}(8 \mathrm{~A})-\mathrm{C}(9 \mathrm{~A})$ & $119.5(3)$ \\
\hline $\mathrm{C}(13 \mathrm{~A})-\mathrm{C}(8 \mathrm{~A})-\mathrm{C}(3 \mathrm{~A})$ & $118.2(3)$ \\
\hline $\mathrm{C}(9 \mathrm{~A})-\mathrm{C}(8 \mathrm{~A})-\mathrm{C}(3 \mathrm{~A})$ & $122.3(3)$ \\
\hline $\mathrm{C}(13 \mathrm{~B})-\mathrm{C}(8 \mathrm{~B})-\mathrm{C}(9 \mathrm{~B})$ & $119.5(4)$ \\
\hline $\mathrm{C}(13 \mathrm{~B})-\mathrm{C}(8 \mathrm{~B})-\mathrm{C}(3 \mathrm{~B})$ & 119.1(4) \\
\hline $\mathrm{C}(9 \mathrm{~B})-\mathrm{C}(8 \mathrm{~B})-\mathrm{C}(3 \mathrm{~B})$ & $121.4(4)$ \\
\hline $\mathrm{C}(10 \mathrm{~A})-\mathrm{C}(9 \mathrm{~A})-\mathrm{C}(8 \mathrm{~A})$ & $121.9(3)$ \\
\hline $\mathrm{C}(10 \mathrm{~A})-\mathrm{C}(9 \mathrm{~A})-\mathrm{O}(1 \mathrm{~A})$ & $121.7(3)$ \\
\hline $\mathrm{C}(8 \mathrm{~A})-\mathrm{C}(9 \mathrm{~A})-\mathrm{O}(1 \mathrm{~A})$ & $116.4(3)$ \\
\hline $\mathrm{C}(10 \mathrm{~B})-\mathrm{C}(9 \mathrm{~B})-\mathrm{O}(1 \mathrm{~B})$ & $121.2(3)$ \\
\hline $\mathrm{C}(10 \mathrm{~B})-\mathrm{C}(9 \mathrm{~B})-\mathrm{C}(8 \mathrm{~B})$ & $121.4(4)$ \\
\hline $\mathrm{O}(1 \mathrm{~B})-\mathrm{C}(9 \mathrm{~B})-\mathrm{C}(8 \mathrm{~B})$ & $117.4(3)$ \\
\hline$C(11 \mathrm{~A})-\mathrm{C}(10 \mathrm{~A})-\mathrm{C}(9 \mathrm{~A})$ & $115.0(3)$ \\
\hline$C(11 A)-C(10 A)-C(24 A)$ & $117.3(3)$ \\
\hline$C(9 A)-C(10 A)-C(24 A)$ & $127.7(3)$ \\
\hline $\mathrm{C}(11 \mathrm{~B})-\mathrm{C}(10 \mathrm{~B})-\mathrm{C}(9 \mathrm{~B})$ & $115.0(4)$ \\
\hline $\mathrm{C}(11 \mathrm{~B})-\mathrm{C}(10 \mathrm{~B})-\mathrm{C}(24 \mathrm{~B})$ & $115.9(3)$ \\
\hline $\mathrm{C}(9 \mathrm{~B})-\mathrm{C}(10 \mathrm{~B})-\mathrm{C}(24 \mathrm{~B})$ & $129.2(4)$ \\
\hline $\mathrm{C}(12 \mathrm{~A})-\mathrm{C}(11 \mathrm{~A})-\mathrm{C}(10 \mathrm{~A})$ & $124.5(4)$ \\
\hline$C(12 B)-C(11 B)-C(10 B)$ & $124.0(4)$ \\
\hline$C(11 A)-C(12 A)-C(13 A)$ & $119.6(4)$ \\
\hline
\end{tabular}




\begin{tabular}{|c|c|}
\hline $\mathrm{C}(11 \mathrm{~B})-\mathrm{C}(12 \mathrm{~B})-\mathrm{C}(13 \mathrm{~B})$ & $119.3(4)$ \\
\hline $\mathrm{C}(12 \mathrm{~A})-\mathrm{C}(13 \mathrm{~A})-\mathrm{C}(8 \mathrm{~A})$ & $119.5(4)$ \\
\hline $\mathrm{C}(8 \mathrm{~B})-\mathrm{C}(13 \mathrm{~B})-\mathrm{C}(12 \mathrm{~B})$ & $120.6(4)$ \\
\hline$C(19 A)-C(14 A)-C(15 A)$ & $119.1(4)$ \\
\hline$C(19 A)-C(14 A)-C(7 A)$ & $118.6(3)$ \\
\hline$C(15 A)-C(14 A)-C(7 A)$ & $122.4(3)$ \\
\hline$C(19 B)-C(14 B)-C(15 B)$ & $119.0(4)$ \\
\hline $\mathrm{C}(19 \mathrm{~B})-\mathrm{C}(14 \mathrm{~B})-\mathrm{C}(7 \mathrm{~B})$ & $117.3(4)$ \\
\hline$C(15 B)-C(14 B)-C(7 B)$ & $123.6(4)$ \\
\hline $\mathrm{O}(3 \mathrm{~A})-\mathrm{C}(15 \mathrm{~A})-\mathrm{C}(14 \mathrm{~A})$ & $120.1(3)$ \\
\hline $\mathrm{O}(3 \mathrm{~A})-\mathrm{C}(15 \mathrm{~A})-\mathrm{C}(16 \mathrm{~A})$ & $118.9(3)$ \\
\hline$C(14 A)-C(15 A)-C(16 A)$ & $121.0(4)$ \\
\hline $\mathrm{O}(3 \mathrm{~B})-\mathrm{C}(15 \mathrm{~B})-\mathrm{C}(14 \mathrm{~B})$ & $120.4(4)$ \\
\hline$O(3 B)-C(15 B)-C(16 B)$ & $118.5(3)$ \\
\hline$C(14 B)-C(15 B)-C(16 B)$ & $121.1(4)$ \\
\hline$C(17 A)-C(16 A)-C(15 A)$ & $116.2(4)$ \\
\hline$C(17 A)-C(16 A)-C(28 A)$ & $121.4(3)$ \\
\hline$C(15 A)-C(16 A)-C(28 A)$ & $122.4(3)$ \\
\hline$C(17 B)-C(16 B)-C(15 B)$ & $116.7(4)$ \\
\hline $\mathrm{C}(17 \mathrm{~B})-\mathrm{C}(16 \mathrm{~B})-\mathrm{C}(28 \mathrm{~B})$ & $120.5(4)$ \\
\hline $\mathrm{C}(15 \mathrm{~B})-\mathrm{C}(16 \mathrm{~B})-\mathrm{C}(28 \mathrm{~B})$ & $122.7(3)$ \\
\hline$C(16 A)-C(17 A)-C(18 A)$ & $124.0(4)$ \\
\hline $\mathrm{C}(16 \mathrm{~B})-\mathrm{C}(17 \mathrm{~B})-\mathrm{C}(18 \mathrm{~B})$ & $122.7(4)$ \\
\hline$C(19 A)-C(18 A)-C(17 A)$ & $118.5(4)$ \\
\hline $\mathrm{C}(19 \mathrm{~B})-\mathrm{C}(18 \mathrm{~B})-\mathrm{C}(17 \mathrm{~B})$ & $120.2(4)$ \\
\hline $\mathrm{C}(18 \mathrm{~A})-\mathrm{C}(19 \mathrm{~A})-\mathrm{C}(14 \mathrm{~A})$ & $121.1(4)$ \\
\hline$C(18 B)-C(19 B)-C(14 B)$ & $120.1(4)$ \\
\hline$C(21 A)-C(20 A)-C(23 A)$ & $109.9(4)$ \\
\hline$C(21 A)-C(20 A)-C(22 A)$ & $108.3(4)$ \\
\hline$C(23 A)-C(20 A)-C(22 A)$ & $109.6(4)$ \\
\hline$C(21 A)-C(20 A)-C(1 A)$ & $109.0(3)$ \\
\hline$C(23 A)-C(20 A)-C(1 A)$ & $111.9(3)$ \\
\hline$C(22 A)-C(20 A)-C(1 A)$ & $108.0(3)$ \\
\hline $\mathrm{C}(21 \mathrm{~B})-\mathrm{C}(20 \mathrm{~B})-\mathrm{C}(22 \mathrm{~B})$ & $110.5(4)$ \\
\hline$C(21 B)-C(20 B)-C(1 B)$ & 109.1(3) \\
\hline$C(22 B)-C(20 B)-C(1 B)$ & $111.7(4)$ \\
\hline
\end{tabular}




$\begin{array}{ll}\text { C(21B)-C(20B)-C(23B) } & 109.1(4) \\ \text { C(22B)-C(20B)-C(23B) } & 108.4(4) \\ \text { C(1B)-C(20B)-C(23B) } & 108.0(4) \\ \text { C(27A)-C(24A)-C(25A) } & 109.5(3) \\ \text { C(27A)-C(24A)-C(26A) } & 105.7(3) \\ \text { C(25A)-C(24A)-C(26A) } & 108.5(3) \\ \text { C(27A)-C(24A)-C(10A) } & 114.5(3) \\ \text { C(25A)-C(24A)-C(10A) } & 108.7(3) \\ \text { C(26A)-C(24A)-C(10A) } & 109.7(3) \\ \text { C(26B)-C(24B)-C(25B) } & 105.9(4) \\ \text { C(26B)-C(24B)-C(27B) } & 107.9(4) \\ \text { C(25B)-C(24B)-C(27B) } & 109.8(4) \\ \text { C(26B)-C(24B)-C(10B) } & 116.2(3) \\ \text { C(25B)-C(24B)-C(10B) } & 108.1(4) \\ \text { C(27B)-C(24B)-C(10B) } & 108.9(3) \\ \text { C(31A)-C(28A)-C(29A) } & 107.5(3) \\ \text { C(31A)-C(28A)-C(30A) } & 107.1(3) \\ \text { C(29A)-C(28A)-C(30A) } & 110.7(3) \\ \text { C(31A)-C(28A)-C(16A) } & 110.7(3) \\ \text { C(29A)-C(28A)-C(16A) } & 111.5(3) \\ \text { C(30A)-C(28A)-C(16A) } & 109.3(3) \\ \text { C(29B)-C(28B)-C(16B) } & 112.0(3) \\ \text { C(29B)-C(28B)-C(30B) } & 107.0(4) \\ \text { C(16B)-C(28B)-C(30B) } & 111.9(3) \\ \text { C(29B)-C(28B)-C(31B) } & 109.6(3) \\ \text { C(16B)-C(28B)-C(31B) } & 108.8(3) \\ \text { C(30B)-C(28B)-C(31B) } & 107.3(4) \\ \end{array}$

Symmetry transformations used to generate equivalent atoms: 
Table S12. Anisotropic displacement parameters $\left(\AA^{2} \times 10^{3}\right)$ for 3. The anisotropic displacement factor exponent takes the form: $-2 \pi^{2}\left[h^{2} a^{* 2} U^{11}+\ldots+2 h k a^{*} b^{*} U^{12}\right]$

\begin{tabular}{|c|c|c|c|c|c|c|}
\hline & $\mathrm{U}^{11}$ & $\mathrm{U}^{22}$ & $\mathrm{U}^{33}$ & $\mathrm{U}^{23}$ & $\mathrm{U}^{13}$ & $\mathrm{U}^{12}$ \\
\hline $\mathrm{W}(1 \mathrm{~A})$ & $12(1)$ & $12(1)$ & $16(1)$ & 1(1) & $2(1)$ & $-1(1)$ \\
\hline W(1B) & $15(1)$ & $18(1)$ & $16(1)$ & $0(1)$ & $3(1)$ & $-3(1)$ \\
\hline $\mathrm{O}(1 \mathrm{~A})$ & $15(1)$ & $12(1)$ & $15(1)$ & $2(1)$ & $4(1)$ & $-2(1)$ \\
\hline $\mathrm{O}(1 \mathrm{~B})$ & 19(1) & $13(1)$ & $17(1)$ & $3(1)$ & $4(1)$ & $-3(1)$ \\
\hline $\mathrm{O}(2 \mathrm{~A})$ & $13(1)$ & 21(1) & $21(2)$ & $1(1)$ & $3(1)$ & $1(1)$ \\
\hline $\mathrm{O}(2 \mathrm{~B})$ & $22(1)$ & $23(2)$ & $20(2)$ & $1(1)$ & $4(1)$ & $-2(1)$ \\
\hline $\mathrm{O}(3 \mathrm{~A})$ & $15(1)$ & $12(1)$ & $22(2)$ & $0(1)$ & $2(1)$ & $0(1)$ \\
\hline $\mathrm{O}(3 \mathrm{~B})$ & $21(1)$ & $21(2)$ & $16(1)$ & $-1(1)$ & $3(1)$ & $-6(1)$ \\
\hline$C(1 \mathrm{~A})$ & $13(2)$ & $10(2)$ & $21(2)$ & $1(2)$ & $5(1)$ & $3(1)$ \\
\hline$C(1 B)$ & $20(2)$ & $20(2)$ & $19(2)$ & $-3(2)$ & $2(2)$ & $-8(2)$ \\
\hline$C(2 A)$ & $12(2)$ & $13(2)$ & $20(2)$ & $1(2)$ & $5(1)$ & $-2(1)$ \\
\hline $\mathrm{C}(2 \mathrm{~B})$ & $22(2)$ & $27(2)$ & $15(2)$ & $5(2)$ & $0(2)$ & $-1(2)$ \\
\hline$C(3 \mathrm{~A})$ & $16(2)$ & $18(2)$ & $21(2)$ & $0(2)$ & $10(2)$ & $-3(1)$ \\
\hline $\mathrm{C}(3 \mathrm{~B})$ & $22(2)$ & $29(2)$ & $19(2)$ & $8(2)$ & $1(2)$ & $-2(2)$ \\
\hline$C(4 A)$ & $21(2)$ & $18(2)$ & $26(2)$ & $-2(2)$ & $7(2)$ & $-6(2)$ \\
\hline$C(4 B)$ & $25(2)$ & $29(2)$ & $27(3)$ & $10(2)$ & $2(2)$ & $3(2)$ \\
\hline$C(5 A)$ & $17(2)$ & $27(2)$ & $28(2)$ & $1(2)$ & $-3(2)$ & $-7(2)$ \\
\hline $\mathrm{C}(5 \mathrm{~B})$ & $23(2)$ & $37(3)$ & $36(3)$ & $9(2)$ & $0(2)$ & $3(2)$ \\
\hline$C(6 A)$ & $13(2)$ & $23(2)$ & $26(2)$ & $5(2)$ & $-1(2)$ & $1(2)$ \\
\hline$C(6 B)$ & $20(2)$ & $37(2)$ & $27(3)$ & $2(2)$ & $-2(2)$ & $-7(2)$ \\
\hline$C(7 A)$ & $17(2)$ & $20(2)$ & $19(2)$ & $2(2)$ & $6(2)$ & $-1(2)$ \\
\hline$C(7 B)$ & $22(2)$ & $31(2)$ & $15(2)$ & $2(2)$ & $-1(2)$ & $-4(2)$ \\
\hline $\mathrm{C}(8 \mathrm{~A})$ & $18(2)$ & $14(2)$ & $16(2)$ & $-3(2)$ & $6(2)$ & $-1(1)$ \\
\hline $\mathrm{C}(8 \mathrm{~B})$ & $19(2)$ & $25(2)$ & $19(2)$ & $-1(2)$ & $6(2)$ & $-1(2)$ \\
\hline$C(9 A)$ & $22(2)$ & $12(2)$ & $14(2)$ & $-4(2)$ & $8(2)$ & $-2(1)$ \\
\hline C(9B) & $22(2)$ & $15(2)$ & $16(2)$ & $3(2)$ & $4(2)$ & $-2(2)$ \\
\hline$C(10 A)$ & $18(2)$ & $16(2)$ & $12(2)$ & $-2(2)$ & $4(1)$ & $2(1)$ \\
\hline$C(10 B)$ & $22(2)$ & $20(2)$ & $20(2)$ & $-2(2)$ & $5(2)$ & $-4(2)$ \\
\hline$C(11 \mathrm{~A})$ & $29(2)$ & $18(2)$ & $17(2)$ & $5(2)$ & $6(2)$ & $2(2)$ \\
\hline$C(11 B)$ & $27(2)$ & $23(2)$ & $24(2)$ & $3(2)$ & $9(2)$ & $-6(2)$ \\
\hline$C(12 A)$ & $30(2)$ & $15(2)$ & $22(2)$ & $2(2)$ & $13(2)$ & $-2(2)$ \\
\hline
\end{tabular}




\begin{tabular}{|c|c|c|c|c|c|c|}
\hline$C(12 B)$ & $36(2)$ & $24(2)$ & $23(2)$ & $4(2)$ & $10(2)$ & $-2(2)$ \\
\hline$C(13 A)$ & $23(2)$ & $19(2)$ & $22(2)$ & $-3(2)$ & $12(2)$ & $-2(2)$ \\
\hline$C(13 B)$ & $30(2)$ & $28(2)$ & $20(2)$ & $5(2)$ & $5(2)$ & $4(2)$ \\
\hline $\mathrm{C}(14 \mathrm{~A})$ & $17(2)$ & $17(2)$ & $17(2)$ & $3(2)$ & $0(2)$ & $2(2)$ \\
\hline$C(14 B)$ & $18(2)$ & $31(2)$ & $19(2)$ & $-1(2)$ & $6(2)$ & $-7(2)$ \\
\hline$C(15 A)$ & $16(2)$ & $18(2)$ & $16(2)$ & $3(2)$ & 1(2) & $2(1)$ \\
\hline$C(15 B)$ & $18(2)$ & $30(2)$ & $17(2)$ & $-4(2)$ & $6(2)$ & $-8(2)$ \\
\hline$C(16 A)$ & $22(2)$ & $17(2)$ & $17(2)$ & $2(2)$ & $2(2)$ & $0(2)$ \\
\hline$C(16 B)$ & $21(2)$ & $28(2)$ & $17(2)$ & $-7(2)$ & $10(2)$ & $-9(2)$ \\
\hline$C(17 A)$ & $29(2)$ & $15(2)$ & $23(2)$ & $-2(2)$ & $4(2)$ & $1(2)$ \\
\hline $\mathrm{C}(17 \mathrm{~B})$ & $22(2)$ & $32(2)$ & $26(2)$ & $-10(2)$ & $11(2)$ & $-9(2)$ \\
\hline $\mathrm{C}(18 \mathrm{~A})$ & $23(2)$ & $22(2)$ & $28(2)$ & $0(2)$ & $6(2)$ & $6(2)$ \\
\hline $\mathrm{C}(18 \mathrm{~B})$ & $23(2)$ & $43(3)$ & $22(2)$ & $-9(2)$ & $5(2)$ & $-13(2)$ \\
\hline$C(19 A)$ & $17(2)$ & $21(2)$ & $24(2)$ & $3(2)$ & $3(2)$ & $-1(2)$ \\
\hline$C(19 B)$ & $22(2)$ & $43(3)$ & $17(2)$ & $-2(2)$ & $3(2)$ & $-9(2)$ \\
\hline$C(20 A)$ & $22(2)$ & $16(2)$ & $20(2)$ & $-2(2)$ & $7(2)$ & $-1(2)$ \\
\hline$C(20 B)$ & $31(2)$ & $28(2)$ & $21(2)$ & $0(2)$ & $6(2)$ & $-7(2)$ \\
\hline$C(21 B)$ & $31(2)$ & $39(3)$ & $27(3)$ & $-1(2)$ & $10(2)$ & $-11(2)$ \\
\hline$C(21 A)$ & $94(4)$ & $32(3)$ & $26(3)$ & $-5(2)$ & $15(3)$ & $2(3)$ \\
\hline$C(22 B)$ & $36(3)$ & $63(3)$ & $21(2)$ & $8(2)$ & $7(2)$ & $-10(2)$ \\
\hline$C(22 \mathrm{~A})$ & $54(3)$ & $78(4)$ & $25(3)$ & $22(3)$ & $15(2)$ & $31(3)$ \\
\hline$C(23 B)$ & $73(4)$ & $37(3)$ & $36(3)$ & $-8(2)$ & $30(3)$ & $-8(2)$ \\
\hline$C(23 \mathrm{~A})$ & $51(3)$ & $81(4)$ & $40(3)$ & $-22(3)$ & $30(3)$ & $-29(3)$ \\
\hline$C(24 A)$ & $20(2)$ & $15(2)$ & $20(2)$ & $1(2)$ & $3(2)$ & $1(2)$ \\
\hline$C(24 B)$ & $22(2)$ & $23(2)$ & $30(2)$ & $4(2)$ & $3(2)$ & $-7(2)$ \\
\hline$C(25 \mathrm{~A})$ & $19(2)$ & $29(2)$ & $40(3)$ & $-8(2)$ & $8(2)$ & $1(2)$ \\
\hline$C(25 B)$ & $24(2)$ & $60(3)$ & $42(3)$ & $15(3)$ & $9(2)$ & $-4(2)$ \\
\hline$C(26 B)$ & $19(2)$ & $28(2)$ & $29(2)$ & $7(2)$ & $2(2)$ & $0(2)$ \\
\hline$C(26 \mathrm{~A})$ & $31(2)$ & $30(3)$ & $29(2)$ & $6(2)$ & $0(2)$ & $-2(2)$ \\
\hline$C(27 \mathrm{~A})$ & $16(2)$ & $23(2)$ & $29(2)$ & $5(2)$ & $-1(2)$ & $-2(2)$ \\
\hline $\mathrm{C}(27 \mathrm{~B})$ & $47(3)$ & $25(2)$ & $37(3)$ & $3(2)$ & $-9(2)$ & $-7(2)$ \\
\hline $\mathrm{C}(28 \mathrm{~A})$ & $23(2)$ & $15(2)$ & $23(2)$ & $-2(2)$ & $4(2)$ & $-2(2)$ \\
\hline $\mathrm{C}(28 \mathrm{~B})$ & $25(2)$ & $24(2)$ & $28(2)$ & $-9(2)$ & $9(2)$ & $-8(2)$ \\
\hline$C(29 A)$ & $24(2)$ & $16(2)$ & $33(2)$ & $1(2)$ & $7(2)$ & $-1(2)$ \\
\hline$C(29 B)$ & $29(2)$ & $19(2)$ & $27(2)$ & $0(2)$ & $7(2)$ & $-3(2)$ \\
\hline $\mathrm{C}(30 \mathrm{~A})$ & $27(2)$ & $25(2)$ & $38(3)$ & $-2(2)$ & $-5(2)$ & $-7(2)$ \\
\hline
\end{tabular}




\begin{tabular}{lllllll}
$\mathrm{C}(30 \mathrm{~B})$ & $42(3)$ & $30(2)$ & $39(3)$ & $-11(2)$ & $12(2)$ & $-5(2)$ \\
$\mathrm{C}(31 \mathrm{~B})$ & $26(2)$ & $30(3)$ & $32(3)$ & $-5(2)$ & $9(2)$ & $-2(2)$ \\
$\mathrm{C}(31 \mathrm{~A})$ & $33(2)$ & $19(2)$ & $44(3)$ & $-5(2)$ & $13(2)$ & $-5(2)$ \\
\hline
\end{tabular}

\section{References}

1. Sarkar, S.; McGowan, K. P.; Kuppuswamy, S.; Ghiviriga, I.; Abboud, K. A.; Veige, A. S. J. Am. Chem. Soc. 2012, 134 (10), 4509-4512.

2. Keitz, B. K., Fedorov, A. and Grubbs, R. H. J. Am. Chem. Soc. 2012, 134, 2040-2043

3. Hyvl, J.; Autenrieth, B.; Schrock, R. R. Macromolecules 2015, 48, 3148-3152

4. $\quad$ Forrest, W. P.; Weis, J. G.; John, J. M.; Axtell, J. C.; Simpson, J. H.; Swager, T. M.; Schrock, R. R., J. Am. Chem. Soc. 2014, 136, 10910-10913.

5. O’Dell R., McConville, D.H., Hofmeister, G.E., Schrock, R.R. J. Am. Chem. Soc. 1994, $116,3414-3423$

6. $\quad$ Rosebrugh, L. E.; Marx, V. M.; Keitz, B. K.; Grubbs, R. H. J. Am. Chem. Soc. 2013, 135, 10032-10035

7. SHELXTL2014 (2014). Bruker-AXS, Madison, Wisconsin, USA 